\title{
Empowerment through Poverty Policy: The Evolution of Conditional Cash Transfer Programs in Mexico
}

\author{
by \\ Jessica Lynn Gamarnik
}

A thesis submitted to the Faculty of Graduate and Postdoctoral Affairs in partial fulfillment of the requirements for the degree of

\author{
Master of Arts \\ in \\ Political Economy \\ Carleton University \\ Ottawa, Ontario
}

(C) 2020, Jessica Lynn Gamarnik 


\begin{abstract}
I examine the family of Conditional Cash Transfer Programs (CCTs) in Mexico comprised of Progresa, Oportunidades, and Prospera - hereafter the Program. CCT programs encourage human capital investment in children while providing monetary support to recipients for their immediate needs. I first examine the evolution of the Program from its introduction in 1997 to 2017. I use qualitative primary and secondary research to track the progress of the Program. Oaxaca is used as a case study owing to its high levels of poverty and high concentration of Indigenous citizens. Primary data on poverty in Mexico and Oaxaca is used to contextualized my argument that the Program has failed to meaningfully address poverty in Oaxaca. ENCASEH survey data is then used to examine the outcomes of the program and deconstruct the issues causing its failure. I adopt a composite critical Marxist-Feminist framework with considerations of indigeneity for analysis of the Program.
\end{abstract}




\section{Acknowledgements}

Thank you to my amazing supervisor Dr. Laura Macdonald, without whom I would have never had to confidence or support necessary to complete this gargantuan piece. I also want to thank Dr. Lisa Mills who gave me more support than is required by a second reader and who was integral throughout this process. With all the possible gratitude available to be me in the universe, thank you both so much for your guidance, wisdom, and support in this endeavor.

Thank you so much to Donna for being there for me like a second mother. Throughout my academic success and failures, my attempts to be politically, socially, and philosophically engaged Donna has been like a mother and I will always cherish our chats and lunches.

Thank you to my partner Joshua who I'm sure I have driven crazy by this point. I would like to dedicate this thesis to anyone who has felt the struggle of trying to fight through their daily lives and do better than they did before, keep on keeping on. 


\section{Table of Contents}



Acknowledgements ..........................................................................................................ii

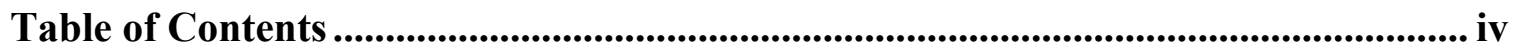

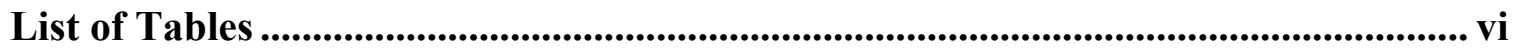

List of Figures........................................................................................................................ vii

Chapter 1: Introduction ............................................................................................................. 1

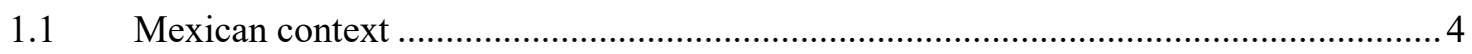

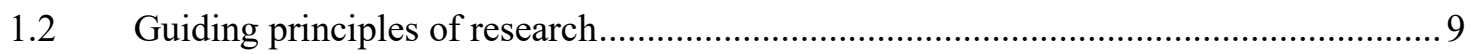

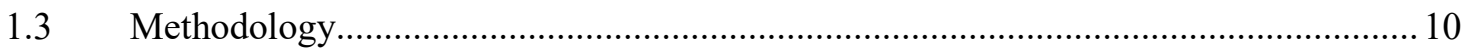

$1.4 \quad$ Contribution to research ...................................................................................... 11

Chapter 2: Conditional Cash Transfers: Theory and Practice ..................................... 13

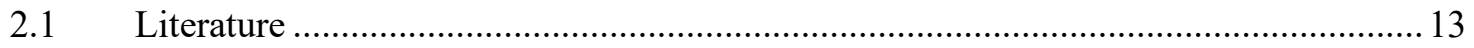



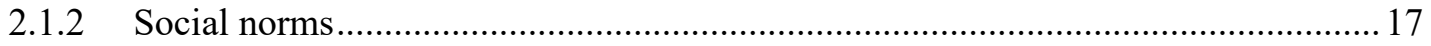

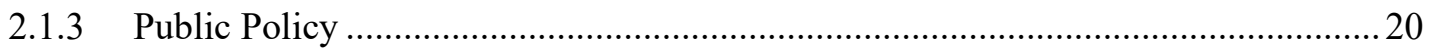

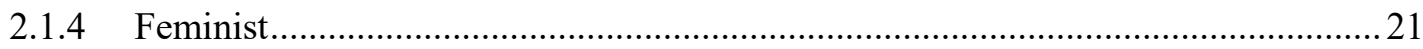

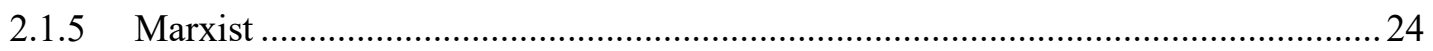

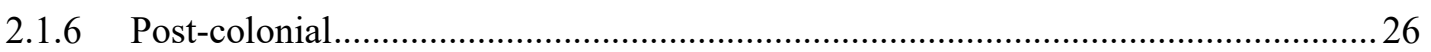

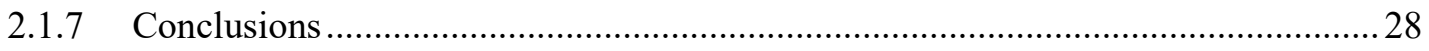

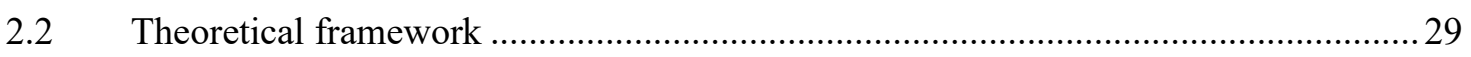



2.2.2 Intergenerational poverty and human capital investment...........................................37

Chapter 3: Historical Evolution of CCTs in Mexico ........................................................ 39

$3.1 \quad$ Political landscape ..............................................................................................4 


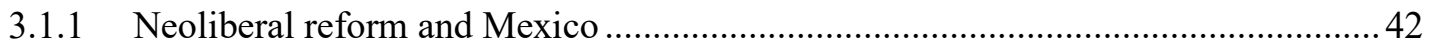

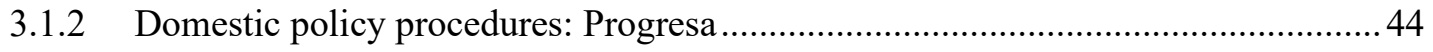

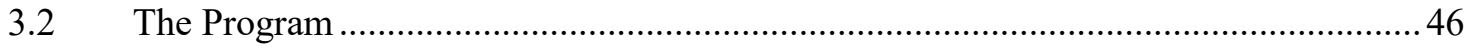

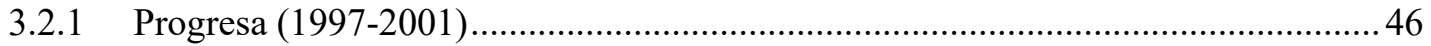

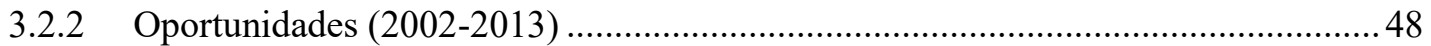



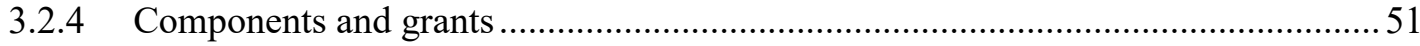

3.3 Community, gendered and intergenerational considerations...................................54

Chapter 4: Program Outcomes: Long-term Recipient Trends ............................... 57

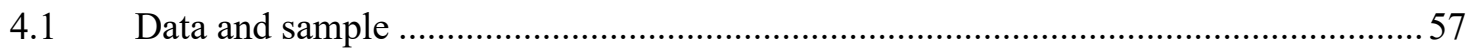



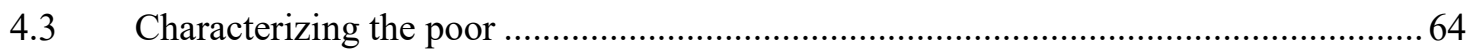

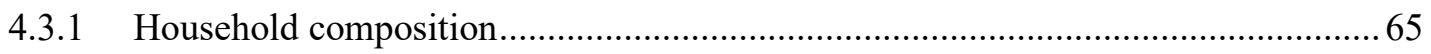

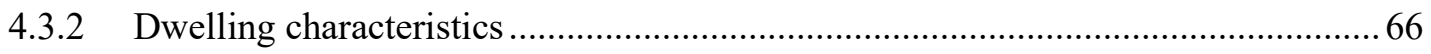

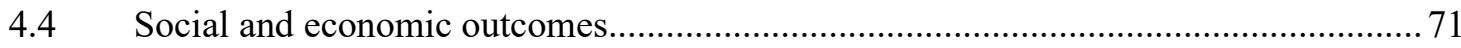



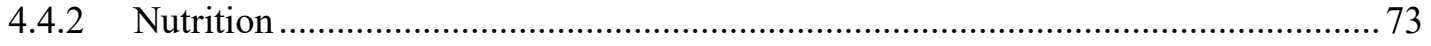

4.4.2.1 Meals and nutritional expenditure ……...................................................... 73

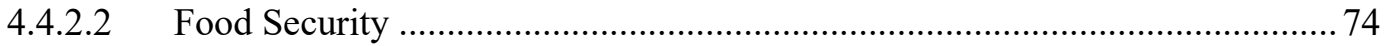

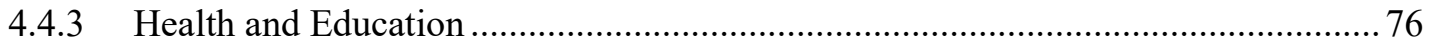

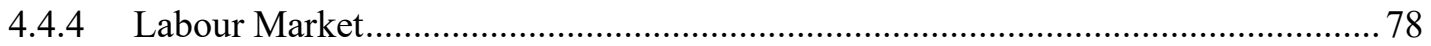

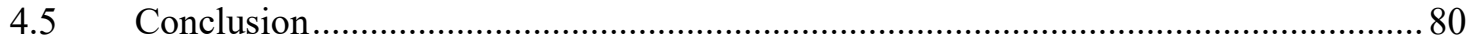

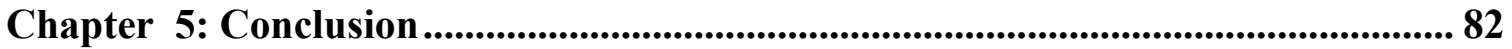

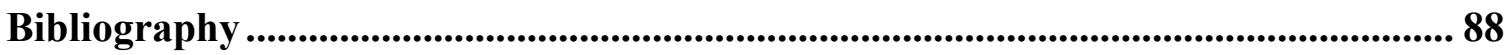




\section{List of Tables}

Table 1: Program Grants, 1997-2017 (USD) …………………………………....... 53

Table 2: Poverty and Extreme Poverty in Mexico and Oaxaca (millions), 2010-2016 ... 63

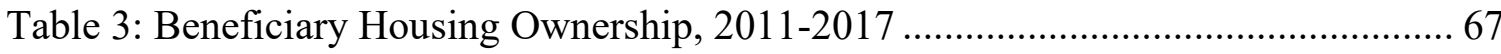

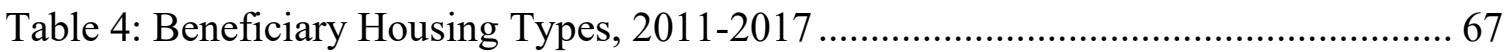

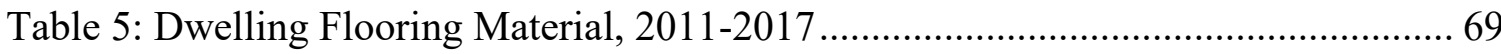

Table 6: Dwelling Roofing Material, 2011-2017 ……………………………………... 70

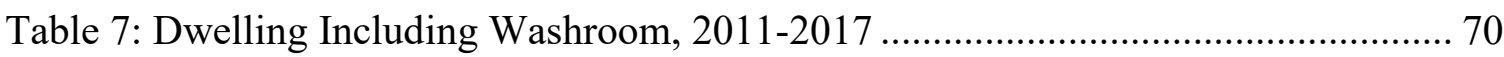

Table 8: Dwelling Access to Water, 2011-2017 ................................................................ 71

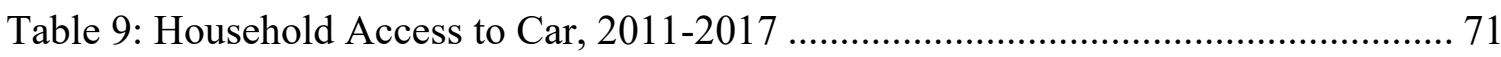

Table 10: Beneficiary Minority Status, 2011-2017 ......................................................... 72

Table 11: Languages Spoken by Beneficiary, 2011-2017 …………………………... 72

Table 12: Households Where Members were Hungry but didn’t Eat, 2011-2017 ........... 75

Table 13: Household Access to Healthcare, 2011-2017 …………………………….... 77

Table 14: Beneficiary Education Level, 2011-2017 ................................................... 78

Table 15: Beneficiary Employment Status, 2011-2017 ................................................. 79

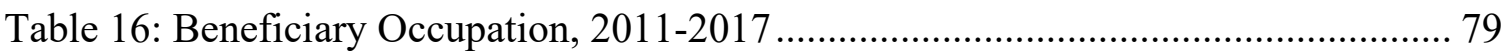




\section{List of Figures}

Figure 1: Parker and Todd Budget and Average Benefits over Time of

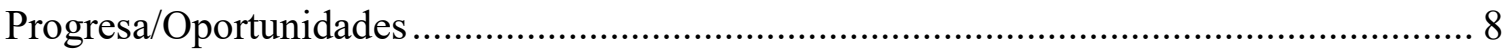

Figure 2: Evolution of the Program's grants and components, 1997-2017 ...................... 51

Figure 3: OECD Poverty Ratio in Mexico, 2014 and 2016 ................................................. 61

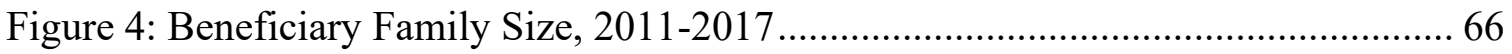

Figure 5: Same Room for Cooking and Sleeping, 2011-2017 ............................................ 68

Figure 6: Usual Number of Meals Consumed per day in Household, 2011-2017............ 74

Figure 7: Monthly Household Nutritional Expenditure ................................................... 74

Figure 8: Households Where One or Fewer Meals was Eaten in a Day, 2011-2017 ....... 75

Figure 9: Households Where an Adult Ran out of Food, 2011-2017 .............................. 76

Figure 10: Beneficiaries who can Read and Write a Message, 2011-2017 ..................... 78

Figure 11: Beneficiary Monthly Income, 2011-2017 ……………………………....... 80 


\section{Chapter 1: Introduction}

Poverty is endemic in Latin America, with higher levels of intensity in rural communities and amongst Indigenous peoples, women and children. ${ }^{1}$ In the 1990s, following the debt crisis of the 1980's, Mexico - like many other Latin American states - found itself in a position of having to provide support vulnerable populations most affected by the neoliberal restructuring of the state that took place. ${ }^{2}$ During the 1970s and 1980s, Western based International Financial Institutions (IFIs) pushed the Global South towards economic liberalization and transformed the role of the state, culminating in the Washington Consensus. ${ }^{3}$ The IFIs leveraged the Latin American debt crisis to achieve the implementation of the tenets of the Washington Consensus in the Global South through Structural Adjustment Programs (SAPs). ${ }^{4}$ Governments and policy leaders blamed the economic instability of the time on the state-centric economic organization in Mexico during the Latin American debt crisis. This lead to the economic reforms towards liberalization beginning under Miguel de la Madrid (1982-1988) and becoming further entrenched under subsequent Partido Revolucionario Institucional (PRI) governments. ${ }^{5}$

In recent decades, neoliberalism has increasingly informed social policies, "enrich[ing] the holders of capital while leading to increasing inequality, insecurity, loss of public services, and a general deterioration of quality of life for the poor and working classes." ${ }^{\prime 6}$ The weakening of social

\footnotetext{
${ }^{1}$ Patrice Franko, The Puzzle of Latin American Economic Development (Lanham: Rowman \& Littlefield Publishing Group, 2007), 385.

${ }^{2}$ Natasha Borges Sugiyama, "The Diffusion of Conditional Cash Transfer Programs in the Americas," Global Social Policy 11 no (2-3): 252-253.

${ }^{3}$ Nora Hamilton, Mexico: Political, Social and Economic Revolution (New York: Oxford University Press, 2011), 109.

${ }^{4}$ Hamilton, Political, Social and Economic Revolution, 109.

${ }^{5}$ Hamilton, Political, Social and Economic Revolution, 107-114.

${ }^{6}$ James Ferguson, “The Uses of Neoliberalism." Antipode 41, no. 1 (2009): 170.
} 
services provided by governments at this time aligns with Peck and Tickell's 'roll-back' neoliberalism period wherein state intervention was effectively delegitimized in favour of market liberalization as the most efficient tool in achieving prosperity. ${ }^{7}$ As poverty deepened throughout the 1990s, there came a need for social policies to ensure the continued legitimacy of neoliberalism in development. This new era, referred to by Peck and Tickell as 'roll-out' neoliberalism, saw the integration of neoliberal tenets with state capacity building. ${ }^{8}$ While attention to poverty became a social policy objective, "policy innovators were still treating social concerns and challenges as a weight on the economy, albeit one that had to be borne - and lightened - in order to achieve larger goals."

The 1994-95 peso crisis which resulted in an additional 16 million people into extreme poverty, allowed the IFIs to leverage further influence on the Mexican state through a 43 billion USD bailout. ${ }^{10}$ The result of this crisis was political instability in which the dominant PRI party's political legitimacy was greatly reduced. ${ }^{11}$ The pressure caused by the crisis and political instability created the opportunity for policy innovation, while maintaining the neoliberal policy agenda. Indeed, this phenomenon is recognized, as Peck argues, as

[the production of policy innovations and 'models' in the context of late neoliberalization] more closely resembles a multipolar regime of continuous (re)mobilization, which is animated and reanimated as much by the failures of earlier waves of misintervention and malregulation as it is by 'blue-sky' strategic visions... these [regimes] represent historically distinctive forms of first- and second-order policy adjustment, operating within

${ }^{7}$ Adam Tickell and Jamie Peck, "Making Global Rules: Globalization or Neoliberalization?" in Remaking the Glabal Economy: Economic-Geographical Perspectives, ed. Jamie Peck and Henry Wai-Chung Yeung (Thousand Oaks: Sage Publications, 2003), 174.

${ }^{8}$ Tickell and Peck, Making Global Rules, 175.

${ }^{9}$ Jane Jenson, "Broadening the Frame: Inclusive Growth and the Social Investment Perspective," in After '08: Social Policy and the Global Financial Crisis ed. Stephen McBride et al (Vancouver: UBC Press, 2015): 44.

${ }^{10}$ Lisa Mills, The Limits of Trust: The Millennium Development Goals, Maternal Health, and Health policy in Mexico (Montreal: McGill University Press, 2017), 64.

${ }^{11}$ James Cypher, "Developing Disarticulation Within the Mexican Economy," Latin American Perspectives 118, no. 3 (2001): 14. 
a neoliberal policy paradigm which combines dogged resilience with serial vulnerability to crisis. But rather than some inexplicable paradox of neoliberalism, this condition seems instead to lie close to its contradictory heart: crises not only for, but of, the neoliberal policy regime repeatedly generate the impetus and the rationale for 'reform', recalibration, and renewal, just as their very urgency seems to further embolden policy-makers, while justifying the need for speed. ${ }^{12}$

Neoliberal policy circles began shifting the focus of social support to long-term targeted social assistance programs once it became clear that the negative impacts of neoliberal restructuring could not be addressed through a patchwork of social assistance programs. ${ }^{13}$ During this era - identified as the post- Washington Consensus period - the focus of the IFIs shifted to 'inclusive' development, in which investment in human capital was targeted through social assistance programs for the impoverished to facilitate their productive participation in the formal labour market. ${ }^{14}$ This is the context in which Conditional Cash Transfer (CCT) programs were first introduced, in both Mexico and Brazil.

This thesis will focus on the CCT program in Mexico. While I find that the Program has been ineffective at eliminating poverty, it should be noted that the Program has been successful at reducing extreme poverty levels in Mexico overall. I will focus my analysis on the state of Oaxaca, located in the southern region of Mexico. I have focused on the state of Oaxaca because of its high levels of poverty, and the fact that the Indigenous populations is larger in this state in comparison to their national representation. In contrast to the Mexican population as a whole, poverty in

12 Jamie Peck, "Geographies of Policy: From Transfer-diffusion to Mobility-mutation," Progress in Human Geography 35, no. 6 (2011): 790.

${ }^{13}$ Peck Geographies of Policy, 790.

${ }^{14}$ Tara Patricia Cookson, Unjust Conditions: Women's Work and the Hidden Cost of Cash Transfer Programs (Oakland: University of California Press, 2018), 7. 
Oaxaca has deepened in the last decade. ${ }^{15}$ Moreover, while Indigenous peoples represent only $10.7 \%$ of the Mexican population, they make up $43.7 \%$ of the population in Oaxaca. ${ }^{16}$ The focus on Oaxaca as a case study highlights the weaknesses of the Program, especially in relation to its outcomes for Indigenous peoples.

The crux of gender targeted CCTs is the sacrifice of the first generation of mothers for the improvement of the future for their children. The introduction of Prospera marks the third iteration of the Program, which was introduced over twenty years previously. These last two decades constitute approximately one generation, which places this project in a uniquely appropriate time period to analyze the intergenerational components of poverty but also to refute the aforementioned claims on the role of mothers in CCTs. In this thesis intergenerational poverty is used to describe situations where cycles of poverty span generations and are characterized by a lack of socially based financial mobility. In the interest of avoiding the pitfalls of universalism and essentializing, context specificity is central to this research.

\subsection{Mexican context}

Mexican president Ernesto Zedillo (1994-2000) launched his new anti-poverty program, Progresa, in 1997. This program targeted only those who were considered to be in extreme poverty in rural areas, serving as justification for fewer and more poorly funded state support agencies. ${ }^{17}$ Under President Fox (2000-2006) of the Partido de Acción Nacional (PAN), Progresa was

\footnotetext{
15 "Población total por Entidad federativa, Grupo quinquenal de edad, Periodo y Sexo," Instituto Nacional de Estadística y Geografía (INEGI), accessed August 17, 2019, https://en.www.inegi.org.mx/app/tabulados/pxweb/inicio.html?rxid=d518b312-a32e-4d23-a8dd$08 \mathrm{a} 64 \mathrm{c} 187 \mathrm{a} 6 \mathrm{c} \& \mathrm{db}=$ Poblacion $\& \mathrm{px}=$ poblacion 01 .

${ }^{16}$ Indicadores socioeconómicos de los pueblos indígena de México, 2015 (Mexico City: Gobierno de México - Comisión nacional para el desarrollo de los pueblos indígenas, 2016), 11.

${ }^{17}$ Lucy Luccisano, "Mexican Anti-Poverty Programs and the Making of "Responsible" Poor Citizens (1995)," (PhD dissertation, York University, 2002), 238-239.
} 
rebranded as Oportunidades and was expanded to include poor urban families and secondary education assistance. ${ }^{18}$ Oportunidades was then further reformed by the Peña Nieto administration (2012-2018) to include further social provisions for youth and the elderly and renamed Prospera in 2014. ${ }^{19}$ Despite the expansion in coverage of the family of CCTs in Mexico - hereafter referred as the Program - beginning under Zedillo in 1997 to its eventual termination following the historic election of Andrés Manuel López Obrador of the Movimiento Regeneración Nacional (MORENA) poverty in Mexico remains a serious issue. In 2016, 43.6\% (53.4 million people) of Mexico's population was considered to be in poverty, $12.3 \%$ ( 9.4 million people) of whom were in extreme poverty. ${ }^{20}$ While this represents an improvement from 2010 levels (46.1\%), the absolute number of those in poverty has increased from 52.8 million people in $2010 .{ }^{21}$ However, comparisons over time are difficult, as the methodology used by CONEVAL to measure poverty changed between 2010 and 2016; therefore, comparisons should be sensitive to differences caused by this change. Moreover, the variations are also not evenly spread across the states. For instance, some poor states, such as Yucatán, saw poverty levels decrease from $48.3 \%(958,500)$ to $41.9 \%(900,100)$ from 2010 to 2016, while other poor states such as Oaxaca saw increases from 67.0\% (2.8 million) to $70.4 \%$ (2.6 million). ${ }^{22}$

${ }^{18}$ Holly Dygert, "The Fight Against Poverty and the Gendered Remaking of Community in Mexico: New Patriarchal Collusions and Gender Solidarities," Political and Legal Anthropology Review 40, no. 1 (2017): 187.

${ }^{19}$ Dygert, The Fight Against Poverty and the Gendered Remaking of Community in Mexico: 187.

20 "Medición de la pobreza, Estados Unidos Mexicanos, 2016," estimations by Consejo Nacional de Evaluación de la Política de Desarrollo Social (CONEVAL), accessed March 8, 2019, https://coneval.org.mx/Medicion/MP/Paginas/Pobreza_2016.aspx.

${ }^{21}$ Medición de la pobreza, Estados Unidos Mexicanos, 2016

22 "Medición de la pobreza, Estados Unidos Mexicanos, 2016: Porcentaje, número de personas y carencias promedia por indicador de pobreza, según entidad federativa, 2010-2016," estimations by Consejo Nacional de Evaluación de la Política de Desarrollo Social (CONEVAL), accessed March 8, 2019, https://coneval.org.mx/Medicion/PublishingImages/Pobreza_2008-2016/medicion-pobreza-entidades-federativas2016.JPG. 
Progresa was the first federally administered 'inclusive development' policy, reflecting the theoretical shift in understanding and administration of poverty. ${ }^{23}$ In other words, "[p]reviously, social welfare was concerned with protecting people from the market. Now, social investment is about integrating people with increased capabilities into the market." ${ }^{24}$ The structure of the Program - although focused on poverty alleviation - is such that the response from government is minimal and thereby conforms with neoliberal economic norms introduced following the debt crisis. ${ }^{25}$ Given both the internal pressures to address systemic poverty in the Global South and the neoliberal environment in which these policies were conceptualized, it is unsurprising that they came to be widespread after their introduction in the late 1990s.

The conditionality of the Program reinforces the belief that the poor are poor owing to their own actions or insufficiencies, not the structural inequalities originating from colonial rule and perpetuated through the neoliberal world order. Even at a general level, the stereotype of the irresponsible poor is unfounded: quantitative analysis has shown that the poor use their resources efficiently when they are available, making state use of conditional or in-kind transfers the less efficient option. ${ }^{26}$ The introduction of the Program represented a shift towards the "depolitization of social policies, since beneficiaries were selected through an elaborate social census rather than

\footnotetext{
${ }^{23}$ Medición de la pobreza, Estados Unidos Mexicanos, 2016: Porcentaje, número de personas y carencias promedia por indicador de pobreza, según entidad federativa.

${ }^{24}$ Lucy Luccisano, "The Mexican Oportunidades Program: Questioning the Linking of Security to Conditional Social Investments for Mothers and Children," Canadian Journal of Latin American \& Caribbean Studies 31, no. 62 (2006): 59.

${ }^{25}$ Natasha Borges Sugiyama, "Bottom-up Policy Diffusion: National Emulation of a Conditional Cash Transer Program in Brazil," Publius 42, no. 1 (2012): 32.

${ }^{26}$ Jesse Cunha, “Testing Paternalism: Cash Versus In-Kind Transfers," American Economic Journal: Applied Economics 6, no. 2 (2014): 228.
} 
through their affiliation with the governing party." 27 In this context depolitization refers to the separation of the program from the clientalistic behavior of the state by inserting a purportedly non-biased algorithmic system to determine whether an individual qualifies for the Program. While this analysis focuses on the short-comings of the Program, it is important to recognize that CCTs have been to some degree effective in mitigating the hardships for households in poverty (especially extreme poverty) and promoting human capital. ${ }^{28}$

The Program provides recipients with $\$ 405$ pesos monthly on average with further old age stipends available to household members over the age of $70 .^{29}$ The familial benefit is given conditionally: children are required to attend school and certain health outcomes - such as prenatal nutrition - are monitored. ${ }^{30}$ The purpose of providing this income to impoverished families is to limit the impact of poverty on parents' preference for human capital investment for their children thus enabling improved future labour market outcomes. Therefore, the Program targets the transmission of intergenerational poverty through the labour market mechanism.

The following chart depicts the evolution of the funding and coverage of the Program from its inception until 2010, as calculated by Parker and Todd. ${ }^{31}$

\footnotetext{
${ }^{27}$ Lucy Luccisano, and Laura Macdonald, "The Impact of the Gloabal Financial Crisis on Mexican Social Policy," in After '08: Social Policy and the Global Financial Crisis ed. by Stephen McBride, Rianne Mahon and Gerard Boychuk (Vancouver: UBC Press, 2015), 190.

${ }^{28}$ Laura Rawlings and Gloria Rubio, "Evaluating the Impact of Conditional Cash Transfer Programs," The World Bank Research Observer 20, no. 1 (2005): 51.

${ }^{29}$ Elena Ayala Galí, "El Programa Oportunidades en Garcías y las Relaciones de Género," in Los Retos de la Política Social en México: Combate a la Pobreza y Equidad de Género (dissertation, Benemérita Universidad Autónoma de Puebla, 2016), 238.

${ }^{30}$ Óscar Gil-García, "Gender Equality, community divisions, and autonomy: The Prospera Conditional Cash Transfer Program in Chiapas, Mexico," Current Sociology, 64 no. 3 (2016): 453.

${ }^{31}$ Susan Parker and Petra Todd, "Conditional Cash Transfers: The Case of Progresa/Oportunidades," Journal of Economic Literature 55, no. 3 (2017): 869.
} 
Figure 1: Parker and Todd Budget and Average Benefits over Time of Progresa/Oportunidades

Budget and Average Benefits Over Time: Procresa/Oportunidades

\begin{tabular}{lccccc}
\hline \hline Year & $\begin{array}{c}\text { Total budget as } \% \\
\text { of GDP }\end{array}$ & $\begin{array}{c}\text { Number of } \\
\text { beneficiary } \\
\text { families }\end{array}$ & $\begin{array}{c}\text { Annual benefits } \\
\text { per household } \\
\text { US } \$\end{array}$ & $\begin{array}{c}\text { Annual benefits } \\
\text { 2010 pesos }\end{array}$ & $\begin{array}{c}\text { Average benefits/ } \\
\text { potential benefits }\end{array}$ \\
\hline 1997 & 0.000079 & 219,944 & & & \\
1998 & 0.000720 & $1,618,536$ & 254 & 4,186 & 0.54 \\
1999 & 0.001227 & $2,166,462$ & 316 & 5,455 & 0.69 \\
2000 & 0.001470 & $2,189,720$ & 359 & 5,615 & 0.71 \\
2001 & 0.001802 & $3,018,681$ & 370 & 5,115 & 0.38 \\
2002 & 0.002374 & $4,037,096$ & 324 & 4,838 & 0.36 \\
2003 & 0.002898 & $4,240,000$ & 351 & 5,390 & 0.40 \\
2004 & 0.002933 & $5,000,000$ & 432 & 6,395 & 0.47 \\
2005 & 0.003167 & $5,000,000$ & 474 & 6,409 & 0.47 \\
2006 & 0.003179 & $5,000,000$ & 546 & 7,237 & 0.53 \\
2007 & 0.003218 & $5,000,000$ & 582 & 7,494 & 0.53 \\
2008 & 0.003402 & $5,000,000$ & 571 & 8,791 & 0.59 \\
2009 & 0.003952 & $5,200,000$ & 668 & 9,189 & 0.61 \\
2010 & 0.005127 & $5,800,000$ & 715 & 9,006 & 0.65 \\
\hline
\end{tabular}

Source: Authors' calculations using data from INEGI: inegi.gob.mx, Oportunidades: oportunidades.gob.mx.

Of note are the exponentially increasing number of beneficiary families along with stagnating increases in funding relative to GDP, indicating that the relative value of the benefit is decreasing over time. Familial eligibility for the Program benefit is evaluated once every three years. ${ }^{32}$ However, it is noteworthy that the growth in the number of recipients can be at least partially attributed to the widening of the scope of this program from its rural roots. One must therefore be careful in the interpretation of this growth, which requires attention in the presentation of the research.

\footnotetext{
${ }^{32}$ Rawlings and Rubio, Evaluating the Impact of Conditional Cash Transfer Programs: 38.
} 


\subsection{Guiding principles of research}

This thesis is guided by the following central research question:

Does the Program contribute to poverty reduction and empowerment of recipients and what does empowerment mean in this context?

To fully address the above research question, two sub-questions emerge:

1. How has the Program changed over time? Why?

2. Does the Program have uniform outcomes across all recipients?

Each question acts to narrow the scope of this project. The meaning and measure of empowerment will be central to shaping research design. The meaning attached to empowerment is directly tied to the impact the Program has on the poor. That is to say, the measure of success and/or failure of the program is to be understood in relation to the outcomes of the Program itself. Finally, the outcomes themselves must be examined in the context of the empowerment of recipients to determine what impacts the Program has had and whether this impact is felt by all recipients in the same manner.

I argue that the Program has failed to empower recipients thereby perpetuating intergenerational poverty in Oaxaca, as the program functions to reproduce structural inequalities caused by neoliberal restructuring in Mexico. Indigenous populations are particularly affected by this restructuring, as reflected in their higher levels of intergenerational poverty.

The next section of this paper will review the literature on CCT programs with special attention to literature related to the Program, the purpose of which is to identify different approaches of analysis to date and where they have been lacking. This will then allow me to establish the theoretical framework from which I will critique the Program and the methodology I will adopt. Following this, I will review the evolution of the Program in Mexico from its 
introduction as Progresa to its final iteration, Prospera. This discussion will include establishing the criteria for eligibility, the requirements for titulares - generally female recipients of the Program - under the program, as well as the main differences between each generation of the Program. Finally, I will present primary data I have gathered on poverty in Mexico and Program impacts in Oaxaca. I will first discuss the data that I have gathered, as well as its limitations. Then I will discuss data on the historical levels of poverty in Mexico and Oaxaca. This discussion will be reinforced by my analysis of the Program data which will first focus on the characterization of Program recipients before moving on to the impact on long-term recipients.

\subsection{Methodology}

This project traces the evolution of the Program in Mexico from its introduction in 1997 (then known as Progresa) up to its last form, Prospera, introduced in 2014 and ending in $2019 .{ }^{33}$ I will provide quantitative information and also draw upon government documents and organizational reports (both from government and non-government sources) to support data findings and provide qualitative support to the conclusion I draw. Program reports released by the Program will be used to track its evolution. The information gathered through this process are used to address my first sub-question on the evolution of the Program.

I draw upon statistics from the Consejo Nacional de Evaluación de la Politica de Desarrollo Social (CONEVAL) and the Prospera evaluation program. I investigate demographic characteristics and labour force characteristics such as employment status and individual and household income. Documentation such as reports for the World Bank are used to support my

\footnotetext{
${ }^{33}$ My period of study remains restricted to end in 2017 due to the availability of data at the time I conducted my research.
} 
conclusions as well as provide complementary analysis on the efficacy and administration of the program and its results. This information will be used to support the analysis of the economic and gender empowerment indicators.

I use CONEVAL data to shape the picture of poverty in Mexico. Statistics specifically relating to the Program are drawn from the microdata files on the Program website. This data is collected through two surveys under the Encuesta de caracteristicas socioeconómicas de hogares homologadas (ENCASEH) program. These surveys were administered annually from 2004 to 2018 and collect information from titulares at the household and individual levels. They cover a wide variety of topics including socioeconomic background and demographic information, dwelling and household characteristics, food security, health, education, and labour market information. I use the dataset for households and titulares who have completed four or more surveys since the first Oportunidades survey in 2004. The reason for this choice is because I am interested in studying the intergenerational components of poverty, therefore long-term recipients are of interest. I examine the number of Indigenous recipients; however, this information only became available from 2011 onwards. This information will be used to address my third research question on equality of outcomes of the Program. Since Indigenous peoples are over-represented both in Oaxaca and in terms of Program recipients in this state, this analysis is used to support the argument that the Program has not been effective at eliminating poverty for marginalized groups.

\subsection{Contribution to research}

One area which has been profoundly affected by neoliberal development processes are social welfare policies. Although social welfare programs suffered through neoliberal adjustments, 'common humanity' demanded paternalistic interventions to mitigate the hardships faced by the 
poor in developing countries. ${ }^{34}$ Thus, CCTs became the socially accepted policy through which the Global North perpetuated its domination of the Global South.

There has not been an in-depth tracking of the Program from its inception to its most recent structure, therefore this component of the paper is central to the originality of this piece. Moreover, there has been very limited analysis of empowerment in relation to Indigenous titulares and the inequality of Program outcomes. I also investigate the connection between long-term recipients and their labour and demographic characteristics to establish whether or not they have an impact on long-term recipients. To do so I use quantitative primary research in tandem with qualitative secondary research to form my theoretical critique of the Program.

The first section of this thesis outlines the development of the Program over time. To do so, I will consolidate primary and secondary research to form a comprehensive analysis of the lifespan and development of the Program. This thesis also undertakes an in-depth analysis of the meaning of empowerment, within neoliberal forms of development, in Mexico and focused within the Program. The purpose of this shall be to form a theoretical 'yardstick' against which the outcomes of the Program may be measured. Moreover, this framework shall act as tool through which the inequality of outcomes will be examined for Indigenous titulares.

\footnotetext{
${ }^{34}$ Sarah Radcliffe, "The Shrinking Commons and Uneven Geographies of Development," in Releasing the Commons: Rethinking the Futures of the Commons. Edited by Amin Ash and Howell Philip (New York: Routledge, 2016), 132.
} 


\section{Chapter 2: Conditional Cash Transfers: Theory and Practice}

\section{$2.1 \quad$ Literature}

The purpose of this thesis to investigate how the Program contributes to poverty reduction and empowerment of its recipients. To further guide my research, I investigate how the Program has changed over time and the uniformity - or lack thereof - of its results across recipients. These questions, broadly speaking, are not new in the literature related to CCTs. Rather, this thesis will combine certain methodological and theoretical approaches while also using quantitative research and a timeframe which have not been adopted elsewhere. Moreover, it is rare to see any analysis done at the state level, specifically in the state that I use as a case study: Oaxaca.

This literature review will cover six theoretical traditions that are prominent in their analysis of the Program and CCTs which are: neoliberal, social norms, public policy, feminist, marxist, and post-colonial. It should be noted that there are many cases where authors cross theoretical boundaries such that they employ more than one tradition in the analysis of the Program or CCTs more broadly. However, this literature review attempts to categorize analysis done on this subject based on the main narratives of an author's work and in relation to my own research.

\subsubsection{Neoliberal}

Neoliberal scholars examine CCT programs and their outcomes based on efficiency and economic outcomes. These approaches often use quantitative results as proof of the positivist effects of these programs. Another common theme amongst these authors is the critique of the implementation of these programs and their administration to explain failures of CCTs in their efforts to reduce intergenerational poverty. In sum, a neoliberal approach is defined by its concentration on economic and administrative efficiency. 
Santiago Levy was the architect of the first iteration of the Program, Progresa. He highlights the importance of "responsibility and active participation of parents and all members of the family in improving their own and their children's education, health, and nutritional status by giving them sufficient information on these issues and complete freedom with regard to their decisions about family size, children's education, and spending patterns." ${ }^{35}$ Prospera and its predecessors have fostered some improvements in the daily lives of Mexico's poorest: generating familial health improvements for nutrition and preventative care; encouraging students to attend school; effectively targeting those most in need; and protecting poor households from economic shocks. ${ }^{36}$ Levy highlights the positive outcomes of Progresa, nevertheless the Program has not been able to eliminate the intergenerational transmission of poverty, its purported purpose.

In their book Just Give Money to the Poor, Hanlon et al make the case for the efficacy of CCT programs in redistributing funds in a manner which is both efficient and which can effect lasting social change when properly applied. The authors' central premise is that the poor would spend money appropriately if the funds were available; giving money to those in poverty does not make them lazy but rather allows them the possibility to use the funds to invest in a fashion which would have been previously deemed too risky, but reaps higher rewards. ${ }^{37}$

Borzutzky takes a critical neoliberal approach in her analysis of Chile's CCT program. Chile Solidario. The introduction of this CCT program in $2002^{38}$ followed decades of changing

\footnotetext{
35 Santiago Levy, Progress Against Poverty: Sustaining Mexico's Progresa-Oportunidades Program. (Washington: The Brookings Institution, 2006), 21.

${ }^{36}$ Levy, Progress Against Poverty, 77.

37 Joseph Hanlon et al. Just Give Money to the Poor: The Development Revolution from the Global South. (Boulder: Kumarian Press, 2013), 73-74.

${ }^{38}$ Silvia Borzutzky, "Conditional Cash Transfers in Latin America and Anti-Poverty Policies in Chile: Why is Chile's Market Economy Unable to Reduce Poverty and Inequality?" Poverty \& Public Policy 4, no. 1 (2012): 8.
} 
political structures and economic instability. ${ }^{39}$ Chile Solidario functions in accordance with neoliberal welfare tenets:

On the demand side, the program allows the indigent to become aware of the existence of benefits and services. On the supply side, the program coordinates and guarantees access to municipal services...Chile Solidario works with mothers, providing psychosocial support, subsidies, and access to existing services... Families can be in the program for not more than two years and fulfillment of conditions is enforced through a set of partial contracts that the family signs with [a] case worker. ${ }^{40}$

The growth in poverty from 2006 to 2009 is used by Borzutzky to support her thesis that Chile Solidario failed at addressing poverty in Chile. ${ }^{41}$ Borzutzky concludes that a significantly large cash benefit may, "lead to an increase in consumption", and human capital investments in health and education may have positive long-term impacts on children, but the program has failed to have a meaningful impact on poverty in Chile. ${ }^{42}$

De Brauw and Hoddinott examine the effects of Progresa on school enrollment of the recipients' children. ${ }^{43}$ These authors use data on recipients and their children's enrollment in school based on two 1999 surveys conducted by Mexican government agencies to evaluate Progresa. ${ }^{44}$ The focus on administrative efficiency as the determining factor in the Progresa's success qualify this work as a neoliberal approach. The requirement of school enrollment as a condition for the receipt of benefits under Progresa had little effect on enrollment at the primary

${ }^{39}$ Borzutzky, Conditional Cash Transfers in Latin America and Anti-Poverty Policies in Chile, 6-10.

${ }^{40}$ Borzutzky, Conditional Cash Transfers in Latin America and Anti-Poverty Policies in Chile, 8-9.

${ }^{41}$ Borzutzky, Conditional Cash Transfers in Latin America and Anti-Poverty Policies in Chile, 13.

42 Borzutzky, Conditional Cash Transfers in Latin America and Anti-Poverty Policies in Chile, 18.

${ }^{43}$ Alan De Brauw and John Hoddinott, "Must Conditional Cash Transfer Programs by conditioned to be Effective? The Impact of Conditioning in School Enrollment in Mexico" Journal of Development Economics 96 , no.2 (2011): 360 .

${ }^{44}$ De Brauw and Hoddinott, Must Conditional Cash Transfer Programs by conditioned to be Effective?: 360. 
school level, but a large benefit on enrollment at the secondary school level. ${ }^{45}$ In other words, Progresa had the effect in keeping children in school for longer than they would have without the conditionality associated with the Program. However, this effect was hindered by Progresa's flawed administration, defined by its inability to consistently collect enrolment information of recipients' children, limited by the Program's oversight capacity. ${ }^{46}$

Parker and Todd review the studies which have been conducted on the first two iterations of the Program: Progresa and Oportunidades. This review covers studies published over the period 2000-2015. The authors review studies in five areas: 1) education and time use; 2) health and nutrition; 3) household income, consumption, investment and saving; 4) gender and demography; and 5) political effects. ${ }^{47}$ The authors conclude overall that,

the evidence suggests that Progresa/Oportunidades is an effective program that alleviates poverty and creates few negative incentive effects. Much of the existing evidence, however, uses the data from the initial rural experiement [collected partially through the ENCASEH and ENCEL surveys] and focuses on impacts during the first few years of the Program. Progresa/Oportunidades has now been operating for a decade and a half. ${ }^{48}$

There are several notable gaps within the neoliberal literature on the Program and CCTs. The main gap is a lack of qualitative analysis on the origin of the Program and its design or any critique of how the focus on efficiency obscures the negative social implications and other failings of the Program. There is little critique of the Program's failure to have meaningful long-term impacts on poverty levels in Mexico. My research specifically examines these long-term impacts

\footnotetext{
${ }^{46}$ De Brauw and Hoddinott, Must Conditional Cash Transfer Programs by conditioned to be Effective?: 367.

${ }^{47}$ Parker and Todd, Conditional Cash Transfers, 867.

${ }^{48}$ Parker and Todd, Conditional Cash Transfers, 909-910.
} 368.

${ }^{45}$ De Brauw and Hoddinott, Must Conditional Cash Transfer Programs by conditioned to be Effective?: 
through its discussion of the inability of the Program to eliminate or meaningfully decrease poverty for recipients. Furthermore, the state's disregard for the poor and how this is built into the Program, as raised in the critical literature discussed below, does not exist within this tradition. My thesis tracks the history of poverty and social policy in Mexico before, and through the lifespan of the Program. This analysis provides a more in-depth understanding of the structural inequality which has been perpetuated by the state. In so doing, my research challenges the focus on quantitative social and labour market outcomes of the neoliberal tradition.

\subsubsection{Social norms}

Social norms scholars focus on how societal norms influenced the creation of the Program and, in turn, the Program's effects on (re)shaping these norms. These studies look at the manner in which social constructs have impacted the structure of the Program. Moreover, this theoretical tradition examines the limits of CCTs given the social order in Mexico and on a global scale.

The construction of development can be traced to the concept of modernity which posits a dichotomous world structure in which the undeveloped and uncultured Global South is juxtaposed with the developed and educated Global North. ${ }^{49}$ In this context, subjects in the Global South can only be understood through their perceived inferiority to Western subjects: without agency or ability to improve their circumstances which have been created through their own inadequacies. ${ }^{50}$ Hence, the Global South has been constructed in a subordinate position in the global order, creating an opportunity for harmful Western interventions for the purpose of its perpetuation.

\footnotetext{
${ }^{49}$ Arturo Escobar, "Introduction: Development and the Anthropology of Modernity" Encountering Development: The Making and Unmaking of the Third World (Princeton: Princeton University Press, 1995$), 4$.

${ }^{50}$ Escobar, Development and the Anthropology of Modernity ,8-9.
} 
It is in this context that the poor are understood as the cause of their own poverty thereby necessitating the regulation and restriction of their actions through conditioning and specialized targeting while limiting government interventions. This characterizes the first generation of CCTs which remains most prominent in Latin America. Pérez-Meñoz describes this phase as follows,

[The] first type of CCT aims to change the recipients' behavior toward greater investment in human development. In general, this type of CCT has specific mechanisms to monitor, enforce, and sanction behaviors. It specifies sanctions of various severity to those beneficiaries who do not fulfill the conditionalities. In this case the fulfillment of conditions constitutes a central goal of the program itself given that its main goal is to promote human development for the poor. ${ }^{51}$

In other words, CCT programs became popular given the neoliberal development paradigm prevalent at the beginning of their popularity. In this way, CCT programs use conditioning to exert control over the behavior of recipients to align with this paradigm.

Wolf et al. have argued that the introduction of psychological tenets in the conditioning of CCTs such as reward and punitive based incentives would mitigate defiance of conditionalities imposed through these programs. ${ }^{52}$ In other words, the design of the program is such that recipients want to meet the requirements as they value its benefits and do not want to incur penalties. This piece highlights how CCTS use the underlying structures of a rules-based society to achieve improved social outcomes. The fundamental flaw in this understanding and approach is that the authors do not seek to find solutions that challenge the capitalist environment which necessitates the crisis of poverty in the Global South.

\footnotetext{
${ }^{51}$ Cristian Pérez-Muñoz, "What is Wrong with Conditional Cash Transfer Programs," Journal of Social Philosophy 48, no. 4 (2017): 442.

52 Sharon Wolf et al, "Drawing on Psychological Theory to Understand and Improve Anti Poverty Policies," Psychology, Public Policy and Law 19, no. 1 (2013): 5.
} 
The administration of the program is also subject to the construction of society in which it operates. To understand the issues with Prospera, it is prudent to examine the local actors tasked with its implementation. Ramirez provides a well-rounded summary of the issues surrounding the program:

The function of the doctors and nurses is to provide and monitor the different activities in which the families are involved through the programme. Prospera's regulations officially require participants to attend health workshops every month and regular medical checkups... There seems to be, however, a few unofficial requirements in place... These unofficial requirements involve, among other tasks, cleaning the clinic and the streets of the locality and participating in health campaigns... Despite these ambiguities, the evidence suggests that health officers regulate these activities as part of the requirements families have to comply with in order to receive their benefits. ${ }^{53}$

As Ramirez explains, this is effective because titulares often do not view program benefits - in this case health services - as a right and therefore feel the need to maintain positive relationships with administrator. ${ }^{54}$ Co-responsibilities are framed as a form of contract between the state and recipients wherein titulares must meet certain educational, health, and community requirements to receive cash benefits from the state..$^{55}$

The social norms school of CCT analysis covers a varied landscape of research that provides insight on how social norms shape public policy and vice versa. However, authors in this field do not undertake an in-depth analysis of the outcomes of CCTs - or more specifically the Program - on recipients and their long-term and intergenerational implications. This perspective

${ }^{53}$ Viviana Ramirez, "CCTs through a wellbeing lens: The importance of the relationship between front-line officers and participants in the Oportunidades/Prosera programme in Mexico," Social Policy \& Society 15, no. 3 (2016): 453.

${ }^{54}$ Ramirez, CCTs through a wellbeing lens, 458.

${ }^{55}$ Ramirez, CCTs through a wellbeing lens, 452. 
is central to my analysis of the Program. My thesis investigates the impact of societal structures on outcomes and how minority groups are disadvantaged within these structures.

\subsubsection{Public Policy}

Public policy scholars focus on public policy norms' influence on the structure of the CCTs and their effects on the realization of public policies. Similarly, policy diffusion scholars examine the way in which CCT programs begin and how they come to be adopted across states regardless of economic and/or political contexts. This theoretical tradition critiques the way in which social constructions and policy norms are central to the widespread adoption of CCTs.

External forces exerting pressure through the use of their institutional soft power - either in the form of financial incentives or through their role in the formation of professional norms and standards in the development community - were central to the widespread adoption of CCTS in Latin America ${ }^{56}$ In this context the poor are understood as the cause for their own poverty thereby necessitating the regulation and restriction of their actions through conditioning and specialised targeting while limiting the scope of government interventions.

Sugiyama's top-down policy diffusion processes consider the influence of international peer-based professional networks domestically, as well as domestic competition amongst politicians on international policy diffusion. ${ }^{57}$ In other words, the global society of development actors exert pressure on members to conform to policy norms. In a separate paper by Sugiyama, the author shows that CCTs have been adopted across the political spectrum in Latin America, signaling that these policies are not ideologically unique. ${ }^{58}$ As such, Sugiyama argues, states have

\footnotetext{
${ }^{56}$ Natasha Borges Sugiyama, Bottom-up Policy Diffusion, 32.

${ }^{57}$ Borges Sugiyama, Bottom-up Policy Diffusion, 29-30.

${ }^{58}$ Borges Sugiyama, The Diffusion of Conditional Cash Transfer Programs in the Americas, 258.
} 
chosen to adopt CCTs notbased on their performance, but rather based on their electoral popularity amongst those who would see tangible short term benefits.

The public policy tradition of CCT analysis investigates how CCTs became popular and spread across the Global South, in particular Latin America. Authors in this field take the initial introduction of CCTs (i.e. the first sub-national program in Brazil and the first national program in Mexico) as a given. My research delves into the economic and political environment leading to the development, introduction, and expansion of the Program in Mexico.

\subsubsection{Feminist}

Feminist scholarly traditions in CCT analysis are generally critical and focus on the implications of these program on gendered outcomes. Moreover, these studies focus on the gendered construction of the program and its impact on empowerment. These studies are frequently qualitative and focus on the live experiences of recipients. The Program is unique amongst CCT programs in Latin America in that it specifically targets gender inequality in Mexico through a so-called reimagining of gendered roles in the community and household. ${ }^{59}$ Moreover, although the gender targeting of cash benefits is common across CCTs in Latin America, a unique feature in the Mexican context is the increased stipend provided for girls enrolled in secondary school. ${ }^{60}$

The ‘co-responsibility' design of the Program frames poverty and its related issues around the view that the poor are irresponsible, rather than from the perspective of inequality. To this end

\footnotetext{
${ }^{59}$ Marta Ochman, "Políticas sociales y empodermiento de las mujeres Una promesa incumplida." Estudios Políticos, no. 48 (2016): 38.

${ }^{60}$ Sarah Bradshaw, "From Structural Adjustment to Social Adjustment: A Gendered Analysis of Conditional Cash Transfer Programmes in Mexico and Nicaragua," Global Social Policy 8, no. 2 (2008): 192.
} 
titulares must meet health and educational requirements to receive cash transfers. The main burden

of these so-called co-responsibilities are on the poor women, not the state. As Hryciuk describes,

[titulares] are to become new expert mothers watching over the health (including reproductive health), nutrition, and proper behavior of their families. They are charged with reversing gender relations in relationships and families despite the lack of educational programmes on gender equality, health or contraception for men. They are also expected to adopt and start promoting the pro-managerial mind-set and, more generally, individualistic attitudes. ${ }^{61}$

While women's empowerment in CCTs is generally understood through the lens of economic empowerment, the gender targeting of CCTs is not necessarily designed to improve the circumstances of mothers, but rather that of the household. ${ }^{62}$ The underlying assumptions built into the gender targeting of benefits and conditionality requirements are burdensome on women and are not wholly effective in improving gender inequalities.

In addition to the nutritional conditionalities imposed on pregnant women and children, Gil García critiques the requirement of titulares to attend health seminars designed to 'educate' women on the 'appropriate models of motherhood and reproduction' as well as increase unpaid care work responsibilities for women. ${ }^{\prime 63}$ In essence, this is a coercive tactic used on recipients to ensure their adherence to gendered norms related to reproduction and motherhood more broadly.

CCTs are representative of the inherent gendering of poverty and social policies whereby the "hegemonic conceptions of female adults [exist] at the core of a domesticated sphere." ${ }^{64}$ Thus, the Program - and CCTs more generally - use paternalistic frameworks to train women for their

${ }^{61}$ Renata, Hryciuk, "Mothering for Neoliberal Times. Mazahua Women, Poverty and the Cultural Politics of Development in Central Mexico," Polish Sociological Review no. 200 (2017): 535.

${ }^{62}$ Cookson, Working for Inclusion?, 1190.

${ }^{63}$ Gil García, referencing Molyneux, Gender Equality, community divisions, and autonomy, 454.

${ }^{64}$ Radcliffe, The Shrinking Commons and Uneven Geographies of Development, 134. 
roles in society. Wilson argues that the underlying assumption of Prospera appears to be that poor women have no other responsibilities or commitments outside motherhood - conditioning poor women to be 'good' mothers. ${ }^{65}$ The result of this structure is such that it perpetuates and reinforces the gendered norm of women as mothers and caregivers.

Other authors highlight the purpose of the cash benefit being gender targeted towards mothers as an intention to increase their independence and bargaining position within the household. ${ }^{66}$ While this benefit increases with the level of educational attainment of girls to encourage their continued attendance, ${ }^{67}$ to receive the Progresa/Oportunidades benefit, mothers are expected to meet health requirements for themselves and their children assessed through frequent doctor's visits, educational requirements, and provide community labour often in the form of cleaning school buildings. ${ }^{68}$ In this manner, the Program increases the burden of motherhood to receive a benefit which is - given the level of required labour - relatively low in value.

Molyneux highlights that the coerced community participation of women - while technically not required by the Program - is a common practice. ${ }^{69}$ The result is the reproduction of gendered narratives which reinforce women in caregiving roles, negating any positive effects of the cash benefit itself. Moreover, the Program does not require that it be mothers who are the titulares, rather it simply requires a female caregiver to take on this role. As a result, elder

${ }^{65}$ Tamar Diana Wilson, "Mexico's Rural Poor and Targeted Educational and Health Programs.” Human Organization 74, no. 3 (2015): 211.

${ }^{66}$ Claudia Radel et al., "The Gender Dynamics of Conditional Cash Transfers and Smallholder Farming in Calakmul, Mexico," Women's Studies International Forum, 65 (2017): 19.

${ }^{67}$ Mercedes González de la Rocha and Agustín Escobar Latapí, "Indigenous Girls in Rural Mexico: A Success Story?" Girlhood Studies, 9 no. 2 (2016): 67.

${ }^{68}$ Maxine Molyneux, "Mothers at the Service of the New Poverty Agenda: The PROGRESA/Oportunidades Programme in Mexico," in Gender and Social Policy in a Global Context. Edited by Shireen Hassin and Shahra Razavi (New York: Palgrave Macmillan, 2006), 55-56.

${ }^{69}$ González de la Rocha and Escobar Latapí, Indigenous Girls in Rural Mexico, 72. 
daughters are increasingly forced into the role of titular when mothers or grandmothers cannot perform this role in order to prevent the loss the benefit, ${ }^{70}$ thereby further reinforcing women's' traditional role in the household. In other words, household dependence on the cash benefit work to the detriment of daughters in beneficiary households by trapping them in the role of caregiver.

Feminist critiques of the Program and CCTs more broadly present an extremely comprehensive review. There are several key areas which feminist scholars focus their analysis: co-responsibility, empowerment, motherhood, education, perpetuation of gendered norms, etc. While my thesis does not deviate from these feminist themes in its analysis it does differ in the materials from which this analysis is based. As I mentioned previously, feminist critiques of the program are almost exclusively qualitative. I draw upon both qualitative and quantitative sources as the basis of my research. I will add to this body of work through my use of data derived from several quantitative sources, including the ENCASEH recipient and household surveys to support my own gendered analysis of the Program.

\subsubsection{Marxist}

Authors writing in the Marxist tradition of CCT analysis critique these programs as appeasement strategies for those most affected and vulnerable to the capitalist world order. In this school of thought, these programs are understood as a means through which wealthy classes exert and maintain their control over the poor to perpetuate the system from which they benefit through the exploitation of the working and impoverished classes.

Wilson asserts that in line with the integration of the neoliberal paradigm in Mexican policy processes, "targeted conditional cash transfers are workfare, not welfare and, at the time of their

\footnotetext{
${ }^{70}$ Molyneux, Mothers at the Service of the New Poverty Agenda, 458.
} 
introduction in development discourse, represented an abandonment of a discourse on basic human rights." 71 The conditionality imposed on the cash benefit transferred to titulares are used to encourage human capital investment in children to aid in the mismatch between labour skills of beneficiary families and well-paying jobs. ${ }^{72}$ However, the level and quality of education do not address the inequality of opportunity in the Mexican labour market. ${ }^{73}$ As Dapuez explains,

Although family relationships could be modeled by simple economics, and regular transfers of cash might alter poor mothers' behaviours concerning their children, it remains unclear why creators of cash transfers believe that poverty is an endogenous and inheritable phenomenon that parents transmit to their children, rather than a byproduct of social and economic exploitation. ${ }^{74}$

Garmany's analysis of CCTs argues that, "[w]hile these programs provide crucial assistance to poor families [they] also aim to produce an ideal-type neoliberal citizen who is fiscally responsible, economically savvy, and capable of looking after their own welfare." ${ }^{75}$ Within this narrow view, empowerment is based on targeting poverty through the cash benefit provided by CCT programs. Moreover, conditionality is employed against this benefit to promote human capital gains in children thus targeting the intergenerational cyclical component of poverty.

Similar to the gaps in feminist literature related to CCT programs, Marxist literature greatly lacks significant quantitative analysis of the Program. Therefore, my use of various quantitative sources of data in tandem with Marxist analysis represents a unique contribution to this body of

\footnotetext{
${ }^{71}$ Tamar Wilson, "The Informal Economy and Social Programs in Mexico: A Critique," Latin American Perspectives 218, no. 1 (2018): 133.

72 Pablo Yanes, “¿De las transferencias monetarias condicionadas al ingreso ciudadano universal?” Acta Sociológica, no. 70 (2016): 141.

${ }^{73}$ Yanes, "¿De las transferencias monetarias condicionadas al ingreso ciudadano universal?, 141.

${ }^{74}$ Andrès Dapuez, "Supporting a Counterfactual Futurity: Cash Transfers and the Interface between Multilateral Banks, the Mexican State, and its People," The Journal of Latin American and Caribbean Anthropology 21, no. 3 (2016: 571.

${ }^{75}$ Jeff Garmany, "Strategies of conditional cash transfers and the tactics of resistance," Environment and Planning A 49, no. 2 (2017): 376.
} 
literature. In so doing, this adds not only context to theory but provides firm support to my argument that the Program has been ineffective at eliminating poverty in Mexico. Moreover, while Marxist literature has analysed a plethora of varied topics related to CCTs this analysis has not been targeted at the evolution of the Program in Mexico throughout its life. My thesis uses Marxist critiques to contextualize the introduction and subsequent iterations of the Program in tandem with feminist and social norm tenets.

\subsubsection{Post-colonial}

Finally, in recent years some authors have analyzed CCTs from a post-colonial perspective, critiquing these programs' prejudice towards Indigenous peoples and their negative impacts on them. Analysis within this tradition focus on the issues unique to the Indigenous and how their vulnerability in a historically imperial society both influences and is influenced by the CCTs. In other words, these authors study the way in which the disadvantages Indigenous peoples face limit possible outcomes of CCTs on their lives and how these programs are used to perpetuate their destruction.

From this perspective, foundational to the approach of the Program is the concept of social mobility, claiming that investment in human capital is the mechanism through which it may be achieved. Indigenous peoples face many obstacles in relation to empowerment through CCT programs. For example, Indigenous children are twice as likely to work than other children in Latin America. ${ }^{76}$ This issue is particularly salient in the context of individuals and families of Indigenous descent in Mexico. Avila Jaquez and Gabarrot Arenas explain,

\footnotetext{
${ }^{76}$ Luis Lopez-Calva and Harry Patrinos, "Exploring the Differential Impact of Public Interventions on Indigenous People: Lessons from Mexico's Conditional Cash Transfer Program," Journal of Human Development and Capabilities 16, no. 3 (2015): 454.
} 
There is a great proportional relationship between being a peasant in Oaxaca and being Indigenous. Land tenure and Indigenous communities are closely linked concepts. Most of the Indigenous people are dedicated to working the land... Indigenous groups live in economic marginalization by engaging in the primary sector. The study of poverty from the Indigenous context is important, as this population remains out of development because of its ethnic status despite all the efforts that many governments... have done. ${ }^{77} 78$

This quote highlights the connection between labour, social, and financial outcomes to economic and social class within Oaxaca.

The design of Prospera cannot be separated from the "perception of Indigenous people as more sexist, backward, and non-modern ... [the] hegemonic constructions of Indigenous culture, which become a rationale for the post-colonial state to promote policies that engage in a 'paradoxical' 'fixing' of Indigenous identity.",79 During this period the Mexican state also altered its approach to indigeneity and poverty. By rebranding the peasant class as the Indigenous poor, the state was able not only to distance itself from the issues associated with poverty and indigeneity but also from responsibility for Indigenous peoples. ${ }^{80}$

Due to the over-representation of the Indigenous among poor populations in Mexico, Prospera has a disproportionate effect on them. ${ }^{81}$ Therefore the rebranding of Indigenous populations from campesinos to the Indigenous poor, leading to the association of poverty with Indigenous identity, legitimizes the intervention of the state in their traditional practices. This has

\footnotetext{
${ }^{77}$ Carmen Avilá Jaquez and Mariana Gabarrot Arenas, "Retos locales de la política social en México: el funcionamiento del Programa de Desarrollo Humano "Oportunidades" en una comunidad indígena bajo el sistema de gobierno de usos y costumbres," Revista Confines, 5 no. 10 (2009): 70.

${ }^{78}$ Existe una gran relación proporcional entre ser campesino en Oaxaca y ser indígena. La tenencia de la tierra y las comunidades indígena son conceptos estrechamente ligados. La mayor parte de los indígenas se dedican a trabajar la tierra... Los grupos indígenas viven en una marginación económica al dedicarse al sector primario. El estudio de la pobreza desde el contexto indígena es importante, ya que esta población permanece al margen del desarrollo por su condición étnica a pesar de todos los esfuerzos que muchos gobiernos...han realizados. ${ }^{78}$

${ }^{79}$ Avilá Jaquez and Gabarrot Arenas, Retos locales de la política social en México, 455.

${ }^{80}$ Dapuez, Supporting a Counterfactual Futurity, 565.

${ }^{81}$ Dygert, The Fight Against Poverty and the Gendered Remaking of Community in Mexico, 174.
} 
resulted in the policing of Indigenous peoples for the purpose of 'correcting' their behaviours which have exacerbated their circumstances. For example, women have been coerced into tubal litigations to limit family size $\mathrm{e}^{82}$ and therefore the amount of monetary assistance provided. Moreover, this has resulted in a change from individual to communal citizenship through assigning Indigenous titulares with traditionally communal concerns such as maintaining the cleanliness of public spaces. ${ }^{83}$

Literature analyzing CCTs from a post-colonial perspective examine the historical inequality and continued oppression of Indigenous peoples. While I do not take a post-colonial theoretical approach to my analysis, I make consideration of the issues and vulnerabilities experienced in relation to indigenity and miniority status. To do so, I take both a qualitative and quantitative approach, which makes my work unique within this theoretical tradition. Moreover, my use of Oaxaca as a case study, a state in which Indigenous peoples are vastly over-represented, allows me to provide insight into the ways in which the Program perpetuates colonial relationships in a specific setting.

\subsubsection{Conclusions}

Throughout this literature review, I have discussed the main schools of thought which have analyzed CCTs and the Program. These theoretical traditions are: neoliberal, social norms, feminist, marxist and post-colonial. All of these traditions have made unique contributions to this field of study. However, there remain major gaps in the literature that I will examine through my thesis. The two most significant unique contributions that my research represents is tracking the

\footnotetext{
${ }^{82}$ Dygert, The Fight Against Poverty and the Gendered Remaking of Community in Mexico, 175.
}

${ }^{83}$ Dygert, The Fight Against Poverty and the Gendered Remaking of Community in Mexico, 177. 
historical context and evolution of the Program through all three of its iterations. While there have been some authors who have examined parts of the Program, there has been no in-depth analysis from its inception to its final iteration. Moreover, my use of mixed analytical methods, including both quantitative and qualitative research as well as a composite theoretical framework are unique with the literature. To conclude, my research represents a unique blend of research and analytical methods such that it forms an original and meaningful contribution to the body of CCT and the Program research.

\subsection{Theoretical framework}

For the purpose of this project, a composite theoretical framework will be used for analysis of the Program. This composite will primarily draw on Marxist feminist analytical tools complimented by post-colonial consideration on the role of Indigeneity on the construction of poverty. This analytical foundation will be especially useful when examining the gender targeting of the Program. The gendered analysis of the Program for this project will be twofold. First, I will undertake an examination of the role of the program in promoting the work of social reproduction of mothers as caregivers. Silvia Federici asserts that,

The reproduction of 'labor power' reveals the dual character and the contradiction inherent in reproductive labor and, therefore, the unstable, potentially disruptive character of this work. To the extent that labor power can only exist in the living individual, its reproduction must be simultaneously a production and valorization of desired human qualities and capacities, and an accommodation to the externally imposed standards of the labor market. ${ }^{84}$

Thus, the imposition of feminized labour through the conditionality of the Program is used to ensure the reproduction of suitable labour for the global capitalist system which benefits from the

\footnotetext{
${ }^{84}$ Silvia Federici, "The Reproduction of Labor Power in the Global Economy and the Unfinished Feminist Revolution." Revolution at Point Zero: Housework, Reproduction, and Feminist Struggle (Brooklyn: PM Press, 2012), 99.
} 
exploitation of the poor in the Global South. Second, I will emphasize how the Program contributes to the devaluation of feminized labour as a means for its exploitation. ${ }^{85}$ In the context of the Program, this has put the onus of social labour on mothers as their care labour is feminized. As such, the responsibility of meeting the requirements to receive the benefit fall almost uniquely on women, creating a paradox. Without the continued devaluation of feminised labour, the Program could not function, thus ensuring the need for its continuation. Therefore, this CCT program must be viewed as a pacifying policy designed to support the subordination of the Global South within the patriarchal capitalist system.

\subsubsection{What is empowerment?}

The concept of empowerment in development literature is loosely formed, taking on different meanings depending on the context to which it is applied. Analogous to Cookson's discussion of inclusivity, empowerment has become a, "development 'fuzzword': a prolific term that does not refer concretely to any one thing, but rather allows its user to "fill it with meaning." 86 This paper explores the term empowerment, critically examining three broad understanding: economic empowerment, gender empowerment, and social empowerment. The purpose of this exercise will be to establish the failure of CCT programs to empower beneficiaries through which, it will be shown, that the structure of CCTs is such that they fail to empower recipients generally. To this end, the term empowerment shall be discussed and analyzed to establish threshold to which empowerment should be measured and the ways in which it has failed in comparison.

\footnotetext{
${ }^{85}$ Silvia Federici, "The Accumulation of Labor and the Degradation of Women: Constructing 'Difference' in the 'Transition to Capitalism'," Caliban and the Witch (Brooklyn: Autonomedia, 1998), 94-95.

${ }^{86}$ Cookson, Working for Inclusion?, 1188.
} 
The first conception of empowerment of interest is that of economic empowerment. In the context of CCTs, cash benefits are employed such that recipients are economically empowered for the purpose of promoting 'social cohesion'. ${ }^{87}$ Given the capitalist landscape in which CCTs function, "social policies, in principle, cause inherent tension within accumulation regimes, since if in the short term they allow the satisfaction of some needs of the populations, in the long term they guarantee the reproduction of capital" 8889 This quote illuminates the manner in which CCTs actively reproduce the accumulation of capital and thus the capitalist system itself. Within this narrow view, empowerment is based on targeting poverty through the cash benefit provided by CCT programs. Moreover, conditionality is employed against this benefit to promote human capital gains in children, thus targeting the intergenerational component of poverty. As such, the ability of these programs to address present poverty and build human capital in children is the basis upon which economic empowerment will be measured.

Economic empowerment through CCTs is measured by two indicators: first the ability of the cash benefit and related programming to meaningfully impact current levels of poverty, and second the investment in childhood human capital to prevent the intergenerational transmission of poverty. The investment by states in cash transfers is generally too low to adequately address poverty. Indeed, in the case of Nicaragua's Red de Protección Social (RPS), benefits were reduced in nominal terms over the course of the pilot due to inflation, and in real terms once RPS moved

\footnotetext{
${ }^{87}$ Maria Ozanira da Silva e Silva, "Income Transfer Programs as a Strategy Against Poverty in Latin America: Reality and Limits," Social Development Issues 40., no. 2 (2018): 8.

${ }^{88}$ Rebeca Cena and Florencia Chahbenderian, "El abordaje estatal de la pobreza en Programams de Transferencias Monetarias Condicionadas," Revista Latinoamericana de Ciencias Sociales 13, no. 1 (2015): 125.

89 "las políticas sociales, en principio, poseen un lugar tensionado dentro de los regímenes de acumulación, dado que si a corto plazo permiten la satisfacción de algunas necesidades de las poblaciones, a largo plazo garantizan la reproducción del capital."
} 
into the second phase owing to the perception that the same results could be achieved in a more 'cost-effective' manner. ${ }^{90}$ Therefore, the value of the cash benefit of RPS - decreasing over the life of the program - fails to provide the necessary income to successfully eliminate poverty. Moreover, for related programming, Chile's Solidario program was unable to ahieve its goal of decreasing poverty by, "providing employment opportunities."91

In terms of human capital development, "the policy discourse surrounding CCT policy development, primarily its focus on children, the importance of co-responsibility, social justice and addressing by means of education and basic health the intergenerational transmission of poverty, were central to [CCT's] agenda and its domestic intellectual origins." 92 However, the quality of programing has not resulted in the purportedly necessary level of human capital development and also fails to target the capitalist system which perpetuates the cycle of intergenerational poverty. ${ }^{93}$ Although the structure of CCT programming encourages investment in human capital, without the appropriate investment and monitoring by the state of the required social services, the human capital growth necessary to prevent the intergenerational transmission of poverty is not possible. However, even if this condition were to be met, CCTs are a product of the capitalist system and as such, by default, are not tools through which poverty and structural inequality can be eliminated. Put more simply, capitalism requires the poor to function and CCTs simply function to appease this population to prevent internal crises. This structure is unlikely to change as many Latin American governments are restricted through patronage networks,

\footnotetext{
${ }^{90}$ Sarah Bradshaw, From Structural Adjustment to Social Adjustment, 197.

${ }^{91}$ Borzutsky, "Conditional Cash Transfers in Latin America and Anti-Poverty Policies in Chile, 11.

92 Tracy Fenwick, "From CCTs to a social investment welfare state? Brazil's 'new' pro-poor strategy," Development Policy Review, 35, no. 5 (2017): 666.

${ }^{93}$ Cena and Chahbenderian, El abordaje estatal de la pobreza en Programas de Transferencias Monetarias Condicionades, 131-132.
} 
characterized by "repeated interpersonal exchanges of resources for loyalty," a cycle that would be broken by their reform. ${ }^{94}$

Gender empowerment is also a topic of interest to researchers of CCTs. This form of empowerment is less tangible than economic empowerment. Although women's empowerment in CCTs is generally understood through the lens of economic empowerment, the gender targeting of CCTs does not necessarily improve the circumstances of mothers, but rather that of the household. ${ }^{95}$ As summarized by Molyneux, "if women's subordination is to be tackled in development and welfare programmes, these must have some potential to empower women and engage their capabilities in ways that enable them to challenge relations of inequality and at the same time provide some scope for female economic autonomy." ${ }^{96}$ Therefore, to take stock of women's empowerment through CCTs we must consider their relative power position to that of men in society. However, given that economic empowerment has been considered at length throughout the literature, my assessment differs from that of Molyneux's in that empowerment is understood as a multifaceted concept rather than simply improvement to economic conditions of recipients and households.

Central to many CCTs is the transfer of cash benefits to mothers. ${ }^{97}$ The basis for this structure is the belief that mothers are more likely to invest responsibly and equitably in the family than fathers, and thus the benefit will be put to better use in their hands. ${ }^{98}$ Although some women

\footnotetext{
94 Valerie Freeland, "Beyond Robert Jackson: Post-Colonial Realities and the Patronage State," International Politics 54, no. 2 (2017): 128-129.

${ }^{95}$ Cookson, Working for Inclusion?, 1190.

${ }^{96}$ Molyneux, Mothers at the Service of the New Poverty Agenda, 438.

${ }^{97}$ Ozanira da Silva e Silva, Income Transfer Programs as a Strategy against Poverty in Latin America, 6.

98 Jane Jenson and Nora Nagels, "Social Policy Instruments in Motion. Conditional Cash Transfers from Mexico to Peru," Social Policy and Administration 52, no. 1 (2018): 326-327.
} 
reported feeling increased autonomy through the receipt of the Progresa/Oportunidades benefit, empowerment cannot be measured solely through a small increase in income. ${ }^{99}$ The introduction of this income does not inherently imply a redistribution of power within the household or more broadly within society. Rather, it works to perpetuate gender stereotypes of women as caregivers and mothers thus reinforcing women's subordination. This puts the gender targeting of cash benefits in direct conflict with women's empowerment.

The conditioning of the cash benefit also works to subordinate women as those who are unable to meet the eligibility criteria are constructed as "bad" mothers. ${ }^{100}$ Although the gender targeting of cash benefits is common across CCTs in Latin America, a unique feature in the Mexican context is the increased stipend provided for girls enrolled in secondary school. ${ }^{101}$ Although this structure of gender targeted cash incentive appears to work to empower women, its failure to challenge traditional constructions of women that view women solely as caregivers and therefore does not meaningfully transform their place in society. Given the inability of CCTs to challenge women's role in society and their tendency to reinforce this norm, they are not a policy mechanism through which women's empowerment may be achieved.

The final form of empowerment to be considered herein is that of social empowerment. In the context of this paper, social empowerment refers both to those populations which are impoverished but more specifically to Indigenous populations. Social empowerment can only be understood in relation to what Cookson refers to as 'social inclusion'. Quoting Bordia Das, this

\footnotetext{
${ }^{99}$ Molyneux, Mothers at the Service of the New Poverty Agenda, 436.

${ }^{100}$ Chantelle Alena Falconer, "(En)Gendering Equality? Conditional Cash Transfers as National Development in Post-Neoliberal Ecuador," The Journal of Latin American and Caribbean Anthropology, 23, no. 2 (2018): 334.

${ }^{101}$ Bradshaw, From Structural Adjustment to Social Adjustment, 192.
} 
term is defined as, "the process of improving the ability, opportunity, and dignity of people, disadvantaged on the basis of their identity, to take part in society." ${ }^{102}$ Equality of opportunity and discrimination are thus the most tangible indicators of social empowerment.

Indigenous peoples face unique obstacles in relation tosocial empowerment. Although the authors find that CCTs have a great impact on the school enrollment of Indigenous children - this effect is concentrated amongst bilingual Spanish-speaking Indigenous children ${ }^{103}$ - Indigenous people are still faced with much discrimination. In the context of health conditionalities, Indigenous women have experienced racism and mockery for their preference towards traditional birthing practices. ${ }^{104}$ In the first example, one could argue that there is some form of social empowerment occurring, school enrollment for Indigenous children is more likely under CCT regimes. However, this result is not felt equally, and is highly concentrated amongst Spanishspeaking Indigenous children, indicating subordination and discrimination for vulnerable groups. Furthermore, CCT regimes can actively oppress Indigenous women as indicated in the childbirth example. Although the health conditions imposed on pregnant women are intended to decrease child mortality, they necessarily place two ontologies - Western and Indigenous knowledge - in a hierarchical order, whereby Indigenous knowledge is subordinated. Although there is no evidence provided in the literature, it is likely possible the same hierarchical outcome would be produced by the education conditionalities thereby weakening the argument in favour of their empowering effects.

\footnotetext{
102 Cookson Quoting Bordia Das, Working for Inclusion, 1190. 464.

${ }^{103}$ Lopez-Calva Patrinos, "Exploring the Differential Impact of Public Interventions on Indigenous People,

${ }^{104}$ Jenson and Nagel, Social Policy Instruments in Motion, 335.
} 
Molyneux argues that, "[e]mpowering the poor and the disadvantaged should result in their gaining more voice and presence in decision-making arenas that affect their lives and developing the capabilities to enable them escape poverty." ${ }^{105}$ However, the meaning of empowerment is not firm; one understanding empowerment is not wholly distinct from other forms. In an attempt to critically analyze what empowerment means, three conceptions of empowerment have been considered: economic empowerment, gender empowerment, and social empowerment. Cash benefits and human capital development have been shown to be ineffective to achieving economic empowerment. This has been proven through discussion on the inability of cash benefits to address poverty levels and through the structural issues limiting human capital development in children. The second form, gender empowerment, cannot be achieved through the CCT program structure as the Program actively reinforces gender stereotypes and norms thereby perpetuating women's subordinations. Finally, social empowerment was discussed in relation to Indigenous peoples.

The findings of this discussion reflected the limited nature of the literature provided on this topic and therefore social empowerment could be said to have some benefits in terms of child school enrolment. It is likely that these benefits are mitigated by the limited resources and prejudice in the education system. However, given the depth of oppression experienced by Indigenous women in the healthcare system through which Indigenous ontologies were subordinated to western medicine the conclusion that in this regard CCTs fail to foster social empowerment cannot be denied.

${ }^{105}$ Molyneux, Mothers at the Service of the New Poverty Agenda, 429. 


\subsubsection{Intergenerational poverty and human capital investment}

The aim of the Program is to prevent the intergenerational transmission of poverty by targeting what the state sees as suboptimal investment in human capital for the purpose of improving social mobility through improved access to high skill labour markets. ${ }^{106}$ While the program has been effective in achieving its short-term goal in addressing households living in extreme poverty, there is no evidence to suggest it has been successful in preventing its intergenerational transmission. ${ }^{107}$ Inherent in the design of the Program is a tension between longterm and short-term outcomes.

To understand the nature of the conflict between short and long-term goal of the Program, one must examine the outcomes in these time frames. The neoliberalization of Mexico following the Latin American debt crisis of 1982 and its entrenchment in the wake of the 1994-95 peso crisis exacerbated inequality along racial lines. ${ }^{108}$ The rural urban divide became more pronounced in this context as evinced by the deepening of inequality of labour market opportunities for rural as compared to urban youths. ${ }^{109}$

The conditionality imposed on the cash benefit transferred to titulares to encourage human capital investment in children to aid in the mismatch between labour skills of beneficiary families and well-paying jobs. ${ }^{110}$ However, the level and quality of education do not address the inequality of opportunity in the Mexican labour market. ${ }^{111}$ This is because the focus on short-term wellbeing

${ }^{106}$ Iliana Yaschine, "Is Education enough to Overcome Poverty? Analysis of the Occupational Stratification Process of Rural Youths in Mexico," Revista Mexicana de Ciencias Politicas y Sociales 60, no. 3 (2015): 379.

107 Yanes, ¿De las transferencias monetarias condicionadas al ingreso ciudadano universal?, 139.

108 Gil García, Gender Equality, community divisions, and autonomy, 453-455.

109 Yaschine, Is Education enough to Overcome Poverty, 380.

${ }^{110}$ Yanes, ¿De las transferencias monetarias condicionadas al ingreso ciudadano universal?, 141.

111 Yanes, ¿De las transferencias monetarias condicionadas al ingreso ciudadano universal?, 141. 
of impoverished families divert human development narratives from systemic inequalities in Mexico caused by deeper social and economic issues by putting the onus of poverty on the irresponsibility of the poor themselves. This process of redirecting blame reproduces the intergenerational transmission of poverty as it takes attention away from the systemic issues causing it.

The short-term goals related to gender empowerment through increased economic autonomy for women is in direct contradiction with the conditionality of the benefit required by its neoliberal foundation. The reproduction of gendered narratives reinforced women in caregiving roles, negating any positive effects of the cash benefit itself. Furthermore, the short-term empowerment of women through the use of cash benefit also conflicts with their long-term empowerment through human capital investment. As previously mentioned, the Program does not require that mothers be titulares, rather it simply requires a female caregiver to be. As a result, elder daughters are increasingly forced into the role of titular ${ }^{12}$ thereby further reinforcing women's' traditional role in the household.

112 Gil García, referencing Molyneux, Gender Equality, community divisions, and autonomy, 458. 


\section{Chapter 3: Historical Evolution of CCTs in Mexico}

The Program is a product of the neoliberal development agenda which was prevalent at the time of its creation. However, the adoption of neoliberal tenets in relation to social welfare did not occur instantaneously. Rather, this paradigm shift was the product of a changing tide which took place over decades of international intervention and coercion in Mexico. Moreover, the Program evolved within this paradigm throughout its life. I argue that the Program cannot eliminate inequality in Oaxaca, or Mexico more broadly. This is because the Program is a by-product of a capitalist system which necessitates inequality and exploitation of impoverished and vulnerable classes. As well, throughout the lifespan of the Program, the Mexican state remained committed to a neoliberal perspective and failed to promote deeper reforms to the labour market and provision of social benefits in a way that might more adequately address poverty and inequality. As a result, the Program served to protect the neo-liberal state by providing limited benefits to those who suffered most directly from crises resulting from the accumulation of capital by elites, to forestall more radical mobilization in favour of structural reforms.

The first section of this chapter examines the political landscape in Mexico leading up to the creation and implementation of the first iteration of the Program, Progresa. This section examines how economic events and the overall structure of the Mexican economy made it susceptible to international intervention and coerced the state towards adopting neoliberal economic liberalization policies. The next sections of this chapter cover the evolution of the Program. To do so, I examine each iteration of the Program in turn - Progresa, Oportunidades, and Prospera - and analyze their similarities and differences. To this end I also briefly discuss key turning points in Mexican economic and politics resulting in changes to the Program. 


\subsection{Political landscape}

During the 1980's and 1990's, Mexico had several interactions with the International Monetary Fund (IMF) and World Bank (WB) - also known as the IFIs. During this time, and previously, social policies in Mexico, "had a strong political logic and were designed to entrench in power the dominant PRI party by delivering benefits to selected sections of the population organized into corporatist organizations (labour, peasants, and the middle class) in return for political support." ${ }^{113}$ Following the peso crisis of 1994-95, Mexico experienced a dramatic economic downturn that resulted in a rapid increase in poverty levels. ${ }^{114}$ This economic shock paved the way for the 1997 introduction of Mexico's first gender targeted Conditional Cash Transfer (CCT) program, then coined Progresa, aimed at benefitting those most vulnerable groups. ${ }^{115}$ Mexico received funds from the IFIs to stabilize the weak economic position it now held. ${ }^{116}$ This relationship was based on two decades of conditionally tied loans from these IFIs which initiated neoliberal restructuring dating back to the debt crisis. ${ }^{117}$ Remaining social protections were vulnerable to paternalism and clientelism, "whereby the allocation of welfare was in theory given 'unconditionally' by a paternalistic state, though in reality often determined by political allegiance to the dominant Mexican party, the PRI." 118

189.

${ }^{113}$ Luccisano and Macdonald, The Impact of the Global Financial Crisis on Mexican Social Policy, 188-

${ }^{114}$ Paul Cooney, "The Mexican Crisis and the Maquiladora Boom: A Paradox of Development or the Logic of Neoliberalism?" Latin American Perspectives 118, no. 28 (2001): 55.

${ }^{115}$ Judith Teichman, "Multilateral Lending Institutions and Transnational Policy Networks in Mexico and Chile," Global Governance 13, no. 4 (2007): 561.

${ }^{116}$ Ngaire Woods, The Globalizers: The IMF, the World Bank, and Their Borrowers (Ithaca: Cornell University Press, 2007), 100.

${ }^{117}$ Woods, The Globalizers, 84.

${ }^{118}$ Rahel Kunz, "The crisis of social reproduction in rural Mexico: Challenging the "re-privatization of social reproduction' thesis," Review of International Political Economy 17, no. 5 (2010): 918. 
The strength of Mexico's technocratic elite in influencing and executing neoliberal reforms is not unique to the peso crisis. The internalization of the neoliberal agenda by the technocratic elite in Mexican policy procedures is difficult to pin down to a particular point in time, however the election of Salinas reaffirmed the acceptance of neoliberal tenets in Mexican public policy. Gates attributes this transition to Salinas' membership to, "the new breed of [technocrats], foreigneducated professional adept at economic management, rather than being old-style politicians preoccupied with orchestrating the traditional worker and peasant alliances with the state." ${ }^{119}$ For my purpose, the term technocrat is used to refer to, "a self-selecting political and technocratic bureaucracy... lack[ing] constituent responsibilities. ${ }^{" 120}$ In other words, these agents administer and often define the policy directives of the Mexican state while functioning outside of the democratic process. The highly elite socioeconomic background of technocrats in Mexico ensured their interests were represented in the formation of the state's public policy. ${ }^{121}$ Indeed, Teichman asserts that the dialogue between Mexican technocrats and the World Bank following the debt crisis often favoured the former's interests. ${ }^{122}$

The conditionality of the Program mirrors the conditionality of IFI funds, reflecting the internalization of the neoliberal agenda. Moreover, this conditionality represents modern Western imperialism wherein the Global South is subordinated in relation to the North and the poor are

\footnotetext{
${ }^{119}$ Marilyn Gates, "The Debt Crisis and Economic Restructuring: Prospects for Mexican Agriculture in Neoliberalism Revisited: Economic Restructuring and Mexico's Political Future, ed. Gerardo Otero (Boulder: Westview Press, 1996), 48.

${ }^{120}$ Gerado Otero, "Neoliberal Reform and Politics in Mexico: An Overview," in Neoliberalism Revisited: Economic Restructuring and Mexico's Political Future, ed. Gerardo Otero (Boulder: Westview Press, 1996 ), 13.

${ }^{121}$ Miguel Centeno, Democracy Within Reason: Technocratic Revolution in Mexico (Pennsylvania: The Pennsylvania State University Press, 1995), 110.

122 Judith Teichman, "The World Bank and Policy Reform in Mexico and Argentina," Latin American Politics and Society 46 no. 1 (2004): 48.
} 
stereotyped as irresponsible. The result of this internalization has been to reinforce structural inequalities between elites and the poor in Mexico.

\subsubsection{Neoliberal reform and Mexico}

Structural Adjustment Policies (SAPs) were imposed by the IMF on Mexico following the inability of the state to pay its debts during the Latin American debt crisis. ${ }^{123}$ Following the debt crisis of the 1980s and the peso crisis of the 1990s, the Mexican government was forced to make economic adjustments which included, according to Kershaw,

[Currency] devaluation and fiscal and monetary austerity...[and] in practice, the IMF adjustment programs diverted a member country's financial resources toward the repayment of foreign creditors and frequently away from productive activities. As such, IMF adjustment systematically privileged the interests of international creditors at the expense of its member countries' development goals when the two were in contradiction. ${ }^{124}$

The austerity measures required by SAPs greatly diminished the social protections provided to the poor in Mexico. ${ }^{125}$ While SAPs were a product of the roll-back neoliberalism of the $1980 \mathrm{~s}^{126}$ the transition to the roll-out neoliberalism of the 1990s saw IFIs shift the focus of SAPs towards inclusionary policies with social support for impoverished groups. ${ }^{127}$ Indeed, IFIs have historically supported poverty reduction as a component in the structural adjustments governments had to adopt in order to receive funds since the 1990s. ${ }^{128}$

\footnotetext{
2000), 35-36.

${ }^{123}$ Luccisano, Mexican Anti-Poverty Programs and the Making of "Responsible" Poor Citizens (1995-

${ }^{124}$ Paul Kershaw, "Averting a Global Financial Crisis: the US, the IMF, and the Mexican Debt Crisis of 1976," The International History Review 40, no. 2 (2018): 296.

${ }^{125}$ Luccisano, Mexican Anti-Poverty Programs and the Making of "Responsible" Poor Citizens (19952000), 35-36.

126 Tickell and Peck, Making Global Rules, 174

127 Tickell and Peck, Making Global Rules, 176.

128 Woods, The Globalizers, 204-205.
} 
As previously mentioned, the election of Salinas indicated a fundamental shift in Mexico's technocratic elite, one which supported the full execution of the neoliberal agenda. Centeno argues,

Along with accepting and emphasizing personal responsibility, the new [social] policies sought to target the limited welfare funds available to those at the very bottom of the socioeconomic ladder. The new elite judged that welfare policies, rather than helping the least advantaged sectors, had benefitted the middle class. Instead of providing blanket subsidies the [Salinas] regime increasingly emphasized the creation of a bare-bones safety net. Social development was apparently no longer considered a government priority but was replaced by a minimalist conception of a welfare state. ${ }^{129}$

To combat the negative effects of these reforms, the National Solidarity Program (PRONASOL) was introduced under the Salinas administration and "supported public works and social welfare projects such as school repairs, road paving, electricity, water, sewage, and health." ${ }^{130}$ This resulted in the accumulation of capital in the hands of elites and, increasingly, international corporations. ${ }^{131}$

This restructuring was further advanced by the Fox government's assemblage of 'second generation reformers' who, by definition, were supporters of neoliberal reform policies. ${ }^{132}$ As such, IFI directives for liberalization were welcomed in this new environment. However, the volatility of globalized financial markets and the possibility of negative outcomes therein required safety nets for populations who, "have less capacity to bear risk," in the hopes of reaping rewards. ${ }^{133}$ This possibility was manifested in the form of an increase in poverty of 16 million

\footnotetext{
${ }^{129}$ Centeno, Democracy Within Reason, 206.

${ }^{130}$ Luccisano and Macdonald, The Impact of the Global Financial Crisis on Mexican Social Policy, 336.

131 Sylvia Maxfield, Governing Capital: International Finance and Mexican Politics (Ithaca: Cornell University Press, 1990), 115.

${ }^{132}$ Greig Charnock, "Improving the Mechanisms of Global Governance? The Ideational Impact of the World Bank on the National Reform Agenda in Mexico," New Political Economy 11, no. 1 (2006): 80.

${ }^{133}$ Davesh Kapur, “The IMF: A Cure or a Curse?” Foreign Policy no. 111 (1998): 120-121.
} 
individuals ${ }^{134}$ following the pesos crisis. ${ }^{135}$ The subsequent introduction of Progresa under the Zedillo government must be understood in the context of mitigating the hardships created through the liberalization process resulting from the internalization of the neoliberal agenda by Mexico's technocratic elite.

The difference in the role of the Mexican technocratic elite from the debt crisis to the peso crisis can be understood as an internalization of the neoliberal agenda following the latter crisis. This process culminated in the adoption of the North American Free-Trade Agreement (NAFTA) which transferred economic power to the capitalist classes. ${ }^{136}$ This opened up a space for the technocratic elite of Mexico to begin drafting 'innovative' social welfare reforms. ${ }^{137}$

After experiencing modest recovery, the Mexican state loosened neoliberal fiscal austerity measures while at the same time liberalizing trade measures in line with the prescriptions of the Washington Consensus. ${ }^{138}$ These policy transitions acted as both as inflammatory measures and precursors to the peso crisis of 1994-95. In contrast to the Latin American debt crisis that resulted from soaring interest rates causing debt to reach untenable levels, the peso crisis can be directly linked to political and economic instability in Mexico resulting in massive capital flight. ${ }^{139}$ As such, the peso crisis represented an ideological shift in Mexican policy procedures.

\subsubsection{Domestic policy procedures: Progresa}

Woods classifies the evolution of the relationship between the IFIs and Mexican technocrats as including four phases of engagement: (1) material incentives for policy changes carried out by

\footnotetext{
${ }^{134}$ Borges Sugiyama The Diffusion of Conditional Cash Transfer Programs in the Americas, 253-253.

${ }^{135}$ Woods, The Globalizers, 100.

136 Dapuez, Supporting a Counterfactual Futurity, 561.

${ }^{137}$ Dapuez, Supporting a Counterfactual Futurity, 568.

138 Woods, The Globalizer, 86.

${ }^{139}$ Hamilton, Mexico: Political, Social and Economic Evolution, 133.
} 
technocrats; (2) the use of IFI incentives and advice for the advancement of technocrats' power and positions; (3) high level of cooperation between the IFIs and technocrats accompanying institutional consolidation of economic policy, and (4) political changes which impacted both the position of technocrats and the influence of IFIs on domestic policy processes. ${ }^{140}$ It is within the context of the final two phases of engagement which Progresa must be analyzed. Teichman argues that the conception of good social policy is defined by 'technocratic imperatives'. ${ }^{141}$ Poverty alleviation efforts in Mexico were framed within this context.

Neoliberalism has increasingly informed social policies, "enrich[ing] the holders of capital while leading to increasing inequality, insecurity, loss of public services, and a general deterioration of quality of life for the poor and working classes." ${ }^{142}$ The neoliberal development doctrine created a climate in which CCTs were identified as the most appropriate anti-poverty policy, refocusing the blame for widespread poverty in the Global South from global structural inequalities and subjugation to internal failings. ${ }^{143}$ The support for CCTs stemmed from rapidly increasing levels of poverty following the adoption of SAPs in loan recipient countries. ${ }^{144}$ In line with the neoliberal agenda, fostering human capital was central in this approach to poverty alleviation. ${ }^{145}$ Therefore CCTs can be seen to act both as legitimizing the neoliberal agenda while appeasing those who were negatively impacted by its outcomes.

\footnotetext{
140 Woods, The Globalizers, 87-88.

141 Teichman, Multilateral Lending Institutions and Transnational Policy Networks, 570.

${ }^{142}$ Ferguson, The Uses of Neoliberalism, 170.

${ }^{143}$ Lena Lavinas, "2 $21^{\text {st }}$ Century Welfare.” New Left Review 84 (2013): 11.

144 Jenson, "Broadening the Frame, 44.

${ }^{145}$ Charnock, Improving the Mechanisms of Global Governance?, 77.
} 


\subsection{The Program}

The Program was officially discontinued under the AMLO administration in 2019, by which time it had ran for 22 years in total, of which my analysis considers 20 years (i.e. 1997-2017). However, the Program underwent many great changes during this period in terms of objectives, coverage, functionality, and grants. Parker and Todd show that as a percentage of GDP, funding for Oportunidades decreased on a per recipient basis from $0.002898 \%$ of GDP for 4 million recipients in 2002 to $0.005127 \%$ for 5.8 million recipients in $2010 .{ }^{146}$

The discussion below outlines these changes first by Program iteration (i.e. ProgresaOportunidades-Prospera) then by grants and components. The purpose of dividing up the discussion in this manner is to allow for an understanding of how the Program evolved and why and the manner in which these were operationalized in reality.

\subsubsection{Progresa (1997-2001)}

Progresa was first introduced under President Ernesto Zedillo (1994-2000), running from 1997-2001. ${ }^{147}$ Coverage under Progresa was restricted to rural regions in Mexico, where the state claimed that $60 \%$ of households experienced extreme poverty, a level seven times greater than that of urban regions. ${ }^{148}$ Parker and Todd explain,

Levy, one of the principal program architects, in his book on the history of the program, argues that the evaluation results, and particularly their distribution internationally, played a role in not only ensuring the program was continued by the next administration but expanded to urban areas. ${ }^{149}$

${ }^{146}$ Parker and Todd, Conditional Cash Transfers, 910.

${ }^{147}$ Iliana Yaschine, "Progresa-Oportunidades-Prospera, veinte años de historia," in El ProgresaOportunidades-Prospera, a 20 años de su creación, coords. Gonzalo Hernández Licona et al. (Mexico City: CONVEVAL, 2019), 35.

148 Yaschine, Progresa-Oportunidades-Prospera, veinte años de historia, 36.

149 Parker and Todd, Conditional Cash Transfers, 869. 
The guiding document behind Progresa lays out the five objectives of the program:

I. Substantially improving the conditions of education, health and nutrition of poor families, especially children and their mothers, by providing sufficient schooling, quality health care services, and nutritional support.

II. Integrating these services so that schooling is not affected by poor health (i.e. youth malnutrition) or by labour which would hinder children or youth's school attendance.

III. Ensuring that households have sufficient resources for their necessities and for their children to be able to complete a basic education.

IV. Developing responsibility and active participation of parents and all family members to the benefit of children and youth through improvements to their education, health, and nutrition.

V. Promoting participation and community support through Progresa so that educational and health services benefit all families in its active regions thereby integrating various other complimentary efforts and initiatives. ${ }^{150}$

Yaschine reports that the resulting program was,

aimed at populations experiencing conditions of extreme poverty, which sought to simultaneously influence the three factors that were identified as hindering families in poverty from breaking the intergenerational cycle of poverty: nutritional deficiencies (low birth weight and malnutrition), health problems (maternal and child mortality, low cognitive development, preventable diseases, early pregnancy) and limited investment in education (low educational attainment, failure and early school dropout from third grade but more pronounced after high school, especially for girls. ${ }^{151}$ translation.

150 “Progresa: Programa de Educación, Salud y Alimentación,” Progresa (Mexico City, 1998), 39, my

151 Yaschine, Progresa-Oportunidades-Prospera, veinte años de historia, 36. 
The functionality of Progresa was based on co-responsibility, which supported the program's actions by ensuring investment in human capital by the household through the conditionality of grants (this will be further discussed under the grants section). Indeed, the Progresa policy document directly states that,

[Active] participation of parents is irreplaceable for the educational, nutritional, and health improvements of their children. Government efforts in these areas [are only effective] with the active participation of families. In this sense government support is a complement, and never a substitute, of the daily effort that the families themselves makes to overcome poverty. ${ }^{152}$

In this manner, the state put the onus of human capital investment on the household (instead of bearing it) through the conditioning of grant funds. Given the political landscape at the time which was greatly influenced by the neoliberal policy agenda adopted by the technocratic elite in Mexico, it is unsurprising that the Program was built upon paternalistic state intervention on the poor.

\subsubsection{Oportunidades (2002-2013)}

In 2002, as part of the Fox administration's (2000-2006) With You strategy (estrategia Contigo), Progresa was rebranded as Oportunidades. ${ }^{153}$ In 2000, Fox became the first opposition leader to be democratically elected and transition into power without violence, in part due to how well his emphasis on reforming government resonated with voters. ${ }^{154}$ This generation of the Program specifically attempted to eliminate the clientalistic function social programs in Mexico had historically served. ${ }^{155}$

${ }^{152}$ Progresa, 56.

${ }^{153}$ Yaschine, Progresa-Oportunidades-Prospera, veinte años de historia, 40.

${ }^{154}$ Kenneth Greene, Why Dominant Parties Lose: Mexixo's Democratization in Comparaticve Perspective (Cambridge: Cambridge University Press, 2007), 2, 301.

${ }^{155}$ Luccisano and Macdonald, Meico and social provision by the federal district, 340 . 
The objectives under the new generation of the Program remained largely unchanged, however, coverage increased massively under the new scheme. The target population under Oportunidades was expanded from its previously rural base to include those below the poverty threshold in semi-urban and urban regions. ${ }^{156}$ This translates to an increase in coverage from fewer than 1 million households in 1997 to 6.6 million households in 2017, of which semi-urban and urban regions made up $20 \%$ and $27 \%$, respectively. ${ }^{157}$ The change from the Fox to Calderón administrations saw changes to nutritional grants and the addition of the energy related component under the Live Better strategy (estrategia Vivir Mejor) of the latter's administration. Overall, Oportunidades represented a surprising continuity from the main elements of its predecessor, Progresa, but with greater funding. This continuity reflects the fact that the newly elected government shared the neoliberal orientation of the PRI regime that preceded it.

\subsubsection{Prospera (2014-2018)}

Prospera - the final iteration of the Program - came into effect during Peña Nieto's tenure (2012-2018) and ran from 2014 to 2019 under this structure. Peña Nieto's election represented a resurgence in PRI support following more than a decade of PAN governance. In this time the PRI was able to regain support through its rebranding and maintenance of local support, the waning support of the PAN as well as the splintering of votes between the PAN, and the Partido de la Revolución (PRD). ${ }^{158}$ Flores-Macías succinctly summarizes the issues faced by Peña Nieto's administration,

Although Peña Nieto rode to power touting the virtues of the "new PRI" - a seemingly renovated party that had buried corrupt and undemocratic practices - there is evidence not

\footnotetext{
${ }^{156}$ Yaschine, Progresa-Oportunidades-Prospera, veinte años de historia, 40

157 Yaschine, Progresa-Oportunidades-Prospera, veinte años de historia, 41-42.

158 Roger Bartra, The Mexican Transition: Politics, Culture, and Democracy in the Twenty-First Century (Cardiff: University of Wales Press, 2013), 84.
} 
only that the government has been unable to rein in corruption across the bureaucracy, but that the president's inner circle might be part of the problem. Rather than improving oversight, the Peña Nieto administration has been involved in a series of high-profile corruption scandals that remain unresolved and have tainted its legitimacy in the eyes of the public. ${ }^{159}$

The changes to the Program from Oportunidades to Prospera were much farther reaching than those from Progresa to Oportunidades. Progresa and Oportunidades were primarily concerned with alleviating future poverty through present investment in human capital. Prospera, by contrast, was the first iteration to include targets for tackling present poverty as a program objective, "through the promotion of productive and labour activities of its beneficiaries, as well as access to goods and services that favour the exercise of their social rights." 160

The change in the basic objectives of Prospera translated into changes to its functionality. With the purported intention of improving efficiency, access and benefits, Prospera was the first iteration of the Program to coordinate with other social policy programs with similar objectives. This was formalized in 2016 through the integration of Prospera with the Food Support Program (PAL), creating a second version of Prospera which did not include co-responsibility as a central component, while maintaining the original Prospera program in which co-responsibility remained. ${ }^{161}$ This necessitates a distinction in Prospera post-2016 between the version with coresponsibility (previously the entirety of Prospera) and the version without co-responsibility (previously PAL and now Prospera without co-responsibility). ${ }^{162}$ All discussion and analysis in this paper refers to the version of Prospera that retained co-responsibility.

\footnotetext{
${ }^{159}$ Gustavo Flores-Macías, “Mexico’s Stalled Reforms” Journal of Democracy 27, no. 2 (2016): 71.

${ }^{160}$ Yaschine, Progresa-Oportunidades-Prospera, veinte años de historia, 45.

161 Yaschine, Progresa-Oportunidades-Prospera, veinte años de historia, 41.

162 Yaschine, Progresa-Oportunidades-Prospera, veinte años de historia, 41.
} 


\subsubsection{Components and grants}

The Program's first iteration, Progresa (1997-2002), was built on three components: education, health, and nutrition (pictured in Spanish below). While these components are present across the lifespan of the Program, over time these components were expanded and new additions were made as well. Under Oportunidades, three more components (youth opportunities, seniors, and energy) were added. ${ }^{163}$ Prospera saw the addition of the connection component (Componente vinculación), integrating productivity, labour, financial, and social advancement as its four pillars. ${ }^{164}$

Figure 2: Evolution of the Program's grants and components, $1997-2017^{165}$

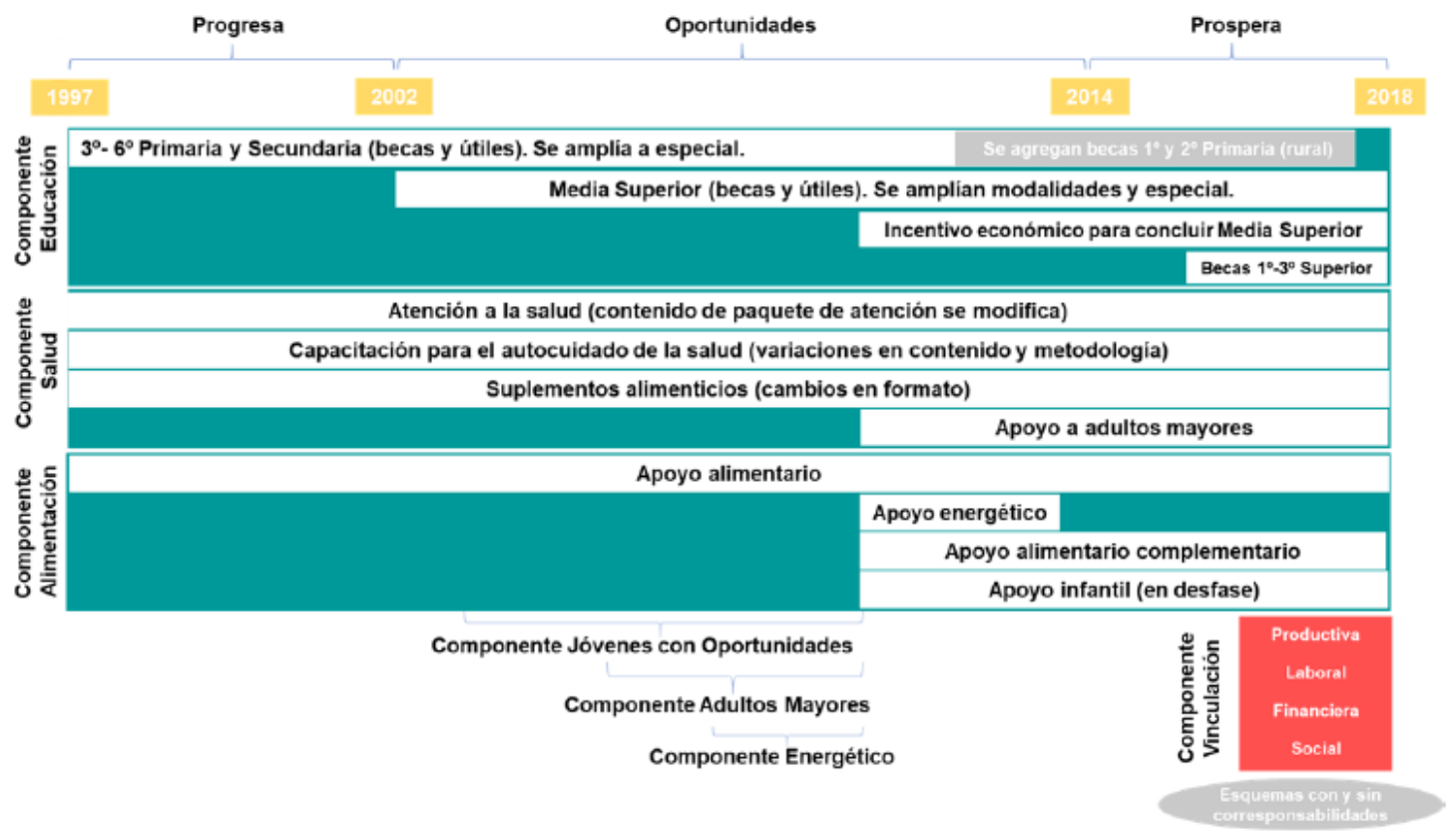

Fuente: Elaborado con base en Progresa (1997), Sedesol (1999, 2000, 2001a, 2002a, 2003, 2004, 2005, 2006, 2007a, 2007b, 2008a, 2009a, 2010a, 2011, 2013a, 2013b, 2014a, 2015a, 2016, 2017) y Prospera (2018n).

Source: Yaschine, 2019.

${ }^{163}$ Yaschine Progresa-Oportunidades-Prospera, veinte años de historia, 46.

${ }^{164}$ Yaschine Progresa-Oportunidades-Prospera, veinte años de historia, 57.

165 Yaschine, Progresa-Oportunidades-Prospera, veinte años de historia, 46. 
The evolution of grants (see Table 1 below) is inherently linked to the changes made to the components pictured above. 
Table 1: Program Grants, 1997-2017 (USD) ${ }^{166} 167$

\begin{tabular}{|c|c|c|c|c|c|c|c|c|c|c|c|c|c|c|c|c|c|c|c|}
\hline & & \multicolumn{2}{|c|}{ Food } & \multicolumn{2}{|c|}{ Education } & \multicolumn{2}{|c|}{$\begin{array}{l}\text { School } \\
\text { Supplies }\end{array}$} & \multicolumn{2}{|c|}{ Youth } & \multicolumn{2}{|c|}{ Seniors } & \multicolumn{2}{|c|}{ Utilities } & \multicolumn{2}{|c|}{$\begin{array}{l}\text { Vivir Mejor: } \\
\text { Food }\end{array}$} & \multicolumn{2}{|c|}{$\begin{array}{l}\text { Vivir Mejor: } \\
\text { Children }\end{array}$} & \multirow[t]{2}{*}{$\begin{array}{l}\text { Min per } \\
\text { capita }^{168}\end{array}$} & \multirow[t]{2}{*}{$\begin{array}{c}\text { Max per } \\
\text { household }^{169}\end{array}$} \\
\hline & & $\min$ & $\max$ & $\min$ & $\max$ & $\min$ & $\max$ & $\min$ & $\max$ & $\min$ & $\max$ & $\min$ & $\max$ & $\min$ & $\max$ & $\min$ & $\max$ & & \\
\hline \multirow{3}{*}{ 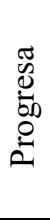 } & 1998 & 11.5 & $\ldots$ & 7.7 & 57.5 & 14.8 & 18.6 & $\ldots$ & $\ldots$ & $\ldots$ & $\ldots$ & $\ldots$ & $\ldots$ & $\ldots$ & $\ldots$ & $\ldots$ & $\ldots$ & 4.1 & 69.0 \\
\hline & 1999 & 13.1 & $\ldots$ & 8.4 & 65.4 & 17.3 & 21.4 & $\ldots$ & $\ldots$ & $\ldots$ & $\ldots$ & $\ldots$ & $\ldots$ & $\ldots$ & $\ldots$ & $\ldots$ & $\ldots$ & 4.6 & 78.4 \\
\hline & 2000 & 14.3 & $\ldots$ & 9.5 & 72.4 & 19.0 & 23.8 & $\ldots$ & $\ldots$ & $\ldots$ & $\ldots$ & $\ldots$ & $\ldots$ & $\ldots$ & $\ldots$ & $\ldots$ & $\ldots$ & 5.1 & 86.7 \\
\hline \multirow{11}{*}{  } & 2002 & 15.5 & $\ldots$ & 10.4 & 79.2 & 20.7 & 25.9 & $\ldots$ & $\ldots$ & $\ldots$ & $\ldots$ & $\ldots$ & $\ldots$ & $\ldots$ & $\ldots$ & $\ldots$ & $\ldots$ & 5.6 & 160.5 \\
\hline & 2003 & 14.4 & $\ldots$ & 9.7 & 73.7 & 19.5 & 24.1 & 27.8 & 278.1 & $\ldots$ & $\ldots$ & $\ldots$ & $\ldots$ & $\ldots$ & $\ldots$ & $\ldots$ & $\ldots$ & 5.2 & 149.2 \\
\hline & 2004 & 13.3 & $\ldots$ & 9.7 & 74.9 & 19.5 & 24.4 & 27.5 & 275.3 & $\ldots$ & $\ldots$ & $\ldots$ & $\ldots$ & $\ldots$ & $\ldots$ & $\ldots$ & $\ldots$ & 5.0 & 151.5 \\
\hline & 2005 & 15.6 & $\ldots$ & 10.6 & 80.3 & 21.1 & 26.2 & 29.3 & 293.3 & $\ldots$ & $\ldots$ & $\ldots$ & $\ldots$ & $\ldots$ & $\ldots$ & $\ldots$ & $\ldots$ & 5.6 & 162.9 \\
\hline & 2006 & 13.8 & $\ldots$ & 11.0 & 84.0 & 22.0 & 27.5 & 30.4 & 304.4 & 22.9 & $\ldots$ & $\ldots$ & $\ldots$ & $\ldots$ & $\ldots$ & $\ldots$ & $\ldots$ & 5.4 & 170.2 \\
\hline & 2007 & 16.0 & $\ldots$ & 11.4 & 87.4 & 22.9 & 28.4 & 31.6 & 316.5 & 23.8 & $\ldots$ & 4.6 & $\ldots$ & $\ldots$ & $\ldots$ & $\ldots$ & $\ldots$ & 6.8 & 181.2 \\
\hline & 2008 & 27.1 & $\ldots$ & 11.7 & 90.7 & 23.8 & 29.7 & 32.3 & 323.3 & 24.7 & $\ldots$ & 4.9 & $\ldots$ & 10.8 & $\ldots$ & $\ldots$ & $\ldots$ & 11.4 & 199.5 \\
\hline & 2010 & 21.8 & $\ldots$ & 11.5 & 88.2 & 23.0 & 28.9 & 32.0 & 320.0 & 24.1 & $\ldots$ & 4.7 & $\ldots$ & 9.5 & $\ldots$ & 7.9 & $\ldots$ & 11.8 & 193.1 \\
\hline & 2011 & 18.1 & $\ldots$ & 12.1 & 93.0 & 24.1 & 30.2 & 33.7 & 337.4 & 25.4 & $\ldots$ & 4.8 & $\ldots$ & 9.7 & $\ldots$ & 8.5 & 25.4 & 11.7 & 202.8 \\
\hline & 2012 & 23.9 & $\ldots$ & 12.1 & 96.4 & 25.1 & 31.5 & 33.8 & 337.9 & 26.2 & $\ldots$ & $\ldots$ & $\ldots$ & 9.9 & $\ldots$ & 8.7 & 26.2 & 12.3 & 203.5 \\
\hline & 2013 & 24.7 & $\ldots$ & 12.9 & 99.4 & 25.8 & 32.5 & 36.0 & 360.1 & 27.0 & $\ldots$ & $\ldots$ & $\ldots$ & 10.2 & $\ldots$ & 9.0 & 27.0 & 12.5 & 216.5 \\
\hline \multirow{4}{*}{ 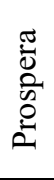 } & 2014 & 25.2 & $\ldots$ & 13.2 & 101.6 & 26.3 & 33.1 & 36.8 & 367.9 & 27.8 & $\ldots$ & $\ldots$ & $\ldots$ & 10.5 & $\ldots$ & 9.0 & 27.1 & 12.5 & 185.8 \\
\hline & 2015 & 25.2 & $\ldots$ & 13.2 & 101.6 & 26.3 & 33.1 & 36.8 & 367.9 & 27.8 & $\ldots$ & $\ldots$ & $\ldots$ & 10.5 & $\ldots$ & 9.0 & 27.1 & 12.5 & 185.8 \\
\hline & 2016 & 21.4 & $\ldots$ & 11.2 & 86.4 & 22.4 & 28.1 & 31.3 & 312.8 & 23.7 & $\ldots$ & $\ldots$ & $\ldots$ & 9.0 & $\ldots$ & 7.7 & 23.0 & 10.7 & 158.0 \\
\hline & 2017 & 18.3 & $\ldots$ & 9.5 & 73.6 & 19.1 & 24.0 & 26.6 & 266.5 & 20.2 & $\ldots$ & $\ldots$ & $\ldots$ & 7.6 & $\ldots$ & 6.5 & 19.6 & 9.1 & 134.6 \\
\hline
\end{tabular}

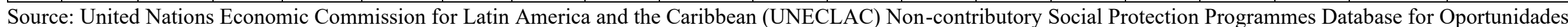
(formerly Progresa) 1997-2014; and Prospera: Social Inclusion Programme (2014-2019).

166 "Non-contributory Social Protection Programmes Database - Oportunidades (Human Development Programme, formerly "Progresa") (1997-2014)," United Nations Economic Commission for Latin America and the Caribbean (UNECLAC), last modified November 16, 2017, https://dds.cepal.org/bpsnc/programme?id=22.

167 "Non-contributory Social Protection Programmes Database - Prospera: Social Inclusion Programme (2014-2019)," UNECLAC, last modified May 29, 2019, https://dds.cepal.org/bpsnc/programme?id=92.

${ }^{168}$ Refers to the minimum any individual could receive in a given household.

${ }^{169}$ Refers to the maximum any household could receive which would be the total received by all individuals in the household if more than one member received grants. 
During Progresa, under the initial three components (education, health, and nutrition) there were three grants (two for education and one for nutrition) with a maximum of $\$ 69.5$ USD per household in 1998 which increased to $\$ 159.50$ USD by $2001 .{ }^{170}$ Several grants were added with the introduction of the new program components under Oportunidades while existing grants remained relatively stable, increasing the maximum per household to \$160.50 USD in 2002 to $\$ 216.50$ in 2013. Several grants were eliminated under Prospera and remaining grants were cut so that the maximum grant per household went from $\$ 185.80$ USD in 2014 to $\$ 134.60$ by 2017 . The decrease in grant funding translates not only to a decrease in the total dollar amount of the grants but also to their value when inflation is taken into account.

\subsection{Community, gendered and intergenerational considerations}

This chapter has argued that the Program has not been able to eliminate poverty in Mexico and, more specifically, Oaxaca. This is because the Program does not address the underlying societal structures causing poverty. On the contrary, being constructed within the neoliberal capitalist system which necessitates the exploitation of the poor is in direct conflict with this goal.

This was first established through an analysis of the political landscape in Mexico preceeding the introduction of Progresa. This section of the chapter argued that inherent in its design is its reactive structure. Progresa was introduced following an economic downturn caused by the liberalization of the Mexican economy which plunged an additonal 16 million individuals into poverty.

\footnotetext{
170 “Non-contributory Social Protection Programmes Database - Oportunidades and Prospera." ECLAC and author calculations.
} 
I then analyzed the evolution of the Program, first by discussing each iteration individually then in comparisons over time. First, I discussed the construction and introduction of Progresa. This iteration was most directly related to the neoliberal paradigm of the time which called for little state intervention, but was also influenced the peso crisis which necessitated some action on the part of the state on behalf of the poor. This is reflected in the conditionality of the Program which seeks to influence recipient behaviour towards responsibility for labour market outcomes. Under this iteration the Program was almost exclusively targeted at rural areas.

Second, under the change from Progresa to Oportunidades, coverage for the Program was expanded to include urban areas and new grants were introduced. While this could be seen as an acceptance of responsibility on the part of the state for poverty, Oportunidades still included key tenets from Progresa that were problematic to its success - most notably the conditionality. Therefore, once more, even as the Program was intended to eliminate poverty for a broader population it did not address the underlying structures causing inequality and poverty and therefore was not successful.

Finally, the current iteration of the Program, Prospera represented a regression from Oportunidades. Under this iteration of the Program grants were cut and qualifying for the Program became more difficult. While the Program had first been touted as an impartial support for impoverished Mexicans, Prospera represented a return to the historically clientelistic behaviour of the Mexican state in its privatization and administration. ${ }^{171}$ The next section of my thesis will

\footnotetext{
${ }^{171}$ Luccisano and Macdonald, The Impact of the Gloabal Financial Crisis on Mexican Social Policy, 189 191.
} 
focus on defining poverty in the Mexican and Oaxacan context and measuring the outcomes of the Program against its intended purpose. 


\section{Chapter 4: Program Outcomes: Long-term Recipient Trends}

Given that CCTs were created in the context of the neoliberal policy agenda, it is important that any analysis consider the structure of these programs and how they are operationalized in their day-to-day administration. The internalization of the neoliberal doctrine by the technocratic elite of Mexico meant not only that poverty programming should be targeted at those considered to be deserving of aid and must elicit desirable activity of recipients but also that the state had to justify the programming through regular evaluation. The evaluation of the Program has been coordinated by SEDESOL with the support of several agencies within Mexico, including CONEVAL, beginning in $1999 .{ }^{172}$

In this chapter I will argue that the Program has not been effective in eliminating poverty, especially for Indigenous populations. The first section of this chapter discusses the data sources I draw on, with special attention to the analytical limitations related to the ENCASEH survey sample long-term recipients. The second section provides a discussion of the historical context poverty in Mexico and more specifically in Oaxaca. The chapter then analyzes of the ENCASEH survey results: first examining demographic characteristics of recipients, followed by the social and economic outcomes of the Program.

\subsection{Data and sample}

In the second section of this chapter I analyze historic poverty in Mexico and Oaxaca. To do so I use several different sources, including CONEVAL and OECD data. The OECD data is used to frame the discussion of poverty in Mexico in relation to the rest of the world using

\footnotetext{
${ }^{172}$ Laura Dávila Lárraga, How Does Prospera Work? Best Practices in the Implementation of Conditional Cash Transfer Programs in Latin America and the Caribbean (Washington, D.C.: Inter-American Development Bank - Social Protection and Health Division, 2016), 51.
} 
consistent indicators. The data from CONEVAL is used to compare poverty at the National level in Mexico to the sub-national level in Oaxaca. It should be noted that due to changes in the reporting of poverty statistics by INEGI CONEVAL adjusted its estimates to be consistent with earlier data that released from 2008-2014. ${ }^{173}$

The data used in this chapter is that of the most recently available period at the time of access, 2017. SEDESOL collected socioeconomic and demographic data for Program recipients at the household and individual level through surveys. This data was collected through several survey programs beginning in 2004 before being merged in 2015 into a single survey program known as Cuestionario Único de Información socioeconómuca e Información Complementaria PROSPERA, Encuesta de Características Socioeconómicas de Hogares (CUIS-ENCASEH). ${ }^{174}$ To facilitate analysis over the whole period the data from previous versions of the survey which were broken apart by into rural and urban datasets were merged and included with the new data collected. ${ }^{175}$ While the titular is supposed to be the respondent to the survey, a proxy may be used in the case that they are unavailable or unable to complete the survey. ${ }^{176}$ Therefore, there are eight datasets differentiated by the number of surveys the recipient household has participated in (one, two, three, and four or more) at the household and individual levels. ${ }^{177}$

173 "Ejecicio de adecuación histórica de la carencia por accesso a la seguridad social 2016 a la serie 20102014," CONEVAL, accessed August 17,2019.

https:/www.coneval.org.mx/Medicion/MP/Documents/Pobreza 16/Notas Pobreza 2016/Nota tecnica 2 ajuste se guridad social.pdf

${ }^{174}$ Nota Técnica de Bases Panel de Encuestas de Características Socioeconómicas de Hogares (ENCASEH) 2004-2018 (Mexico City: SEDESOL - Prospera, 2019), 1.

${ }^{175}$ Nota Técnica de Bases Panel de Encuestas de Características Socioeconómicas de Hogares (ENCASEH) 2004-2018, 1.

${ }^{176}$ Nota Técnica de Bases Panel de Encuestas de Características Socioeconómicas de Hogares (ENCASEH) 2004-2018, 1.

177 “Información Socioeconómica y Demográfica de PROSPERA (Base de Datos)," gob.mx - Prospera, accessed November, 2018, https://evaluacion.prospera.gob.mx/es/dae/encaseh.php. 
As discussed in the previous chapter, a core objective of the Program is the elimination of the intergenerational component of poverty. For this reason, I have chosen to restrict my sample to long-term Program recipients (i.e. those who have taken four or more rounds of surveys) to support this. The earliest period for which this data is available is 2004 . The surveys themselves evolved over time, therefore, some variables of interest are not available for the whole period (i.e. 2004-2017). A main component of my analysis is the inequality of Program outcomes for Indigenous recipients. Data concerning Indigenous ancestry of recipients only becomes available beginning in 2011, restricting the period for analysis to 2011-2017. Beginning in 2015, a question to identify recipients of Afro-Mexican descent was added.

It should be noted that over the lifespan of the program that I analyze (i.e. 1997-2017), the sample size for recipients in Oaxaca decreases. This should not be interpreted as the Program having a greater impact on poverty, but rather as the qualifying criteria becoming more strict such that fewer families are considered to be impoverished. ${ }^{178}$ However, it could also be the case that the value of grants distributed through the Program has declined relative to the cost of living, pushing more households into poverty. In any case, to account for the decreasing sample size, results are presented as percentages to better indicate trends over time.

\subsection{Historical poverty in Mexico and Oaxaca}

Understanding poverty and the discourse surrounding it requires context. The previous chapter explored the history of the Program in Mexico. However, to fully understand how the Program functions in relation to its intended purpose requires putting poverty in Mexico and Oaxaca in context. A good indication of the intensity of poverty in a country is its poverty rate.

\footnotetext{
${ }^{178}$ Discussed in chapter 3 .
} 
The poverty rate, as defined by the OECD is, "the ratio of the number of people (in a give age group) whose income falls below the poverty line; taken as half the median household income of the total population." ${ }^{179}$ Using the most recently available data (2016), Mexico ranks seventh for highest poverty rate overall amongst OECD countries: $15^{\text {th }}$ for the youth $(0-17)$ poverty rate, $16^{\text {th }}$ for working aged (18-65), and $15^{\text {th }}$ amongst seniors $(66+) .{ }^{180}$ Between 2014 (the earliest period for which this information is available) and 2016 (the most recent date for which this information is available), the total poverty rate in Mexico decreased $0.1 \%$ (see Figure 3 ). The only group that saw an increase in the poverty index between these two periods were youth by who saw their poverty index grow $0.01 \%$ to 0.198 in $2016 .{ }^{181}$ More detailed poverty figures for Mexico and Oaxaca are presented later in this section.

179 “Poverty Rate," OECD, accessed August 17, 2019, https://data.oecd.org/inequality/povertyrate.htm\#indicator-chart.

180 "Poverty Rate," OECD, accessed August 17, 2019, https://data.oecd.org/inequality/povertyrate.htm\#indicator-chart.

181 "Poverty Rate," OECD, accessed August 17, 2019, https://data.oecd.org/inequality/povertyrate.htm\#indicator-chart and author calculations. 
Figure 3: OECD Poverty Ratio in Mexico, 2014 and 2016

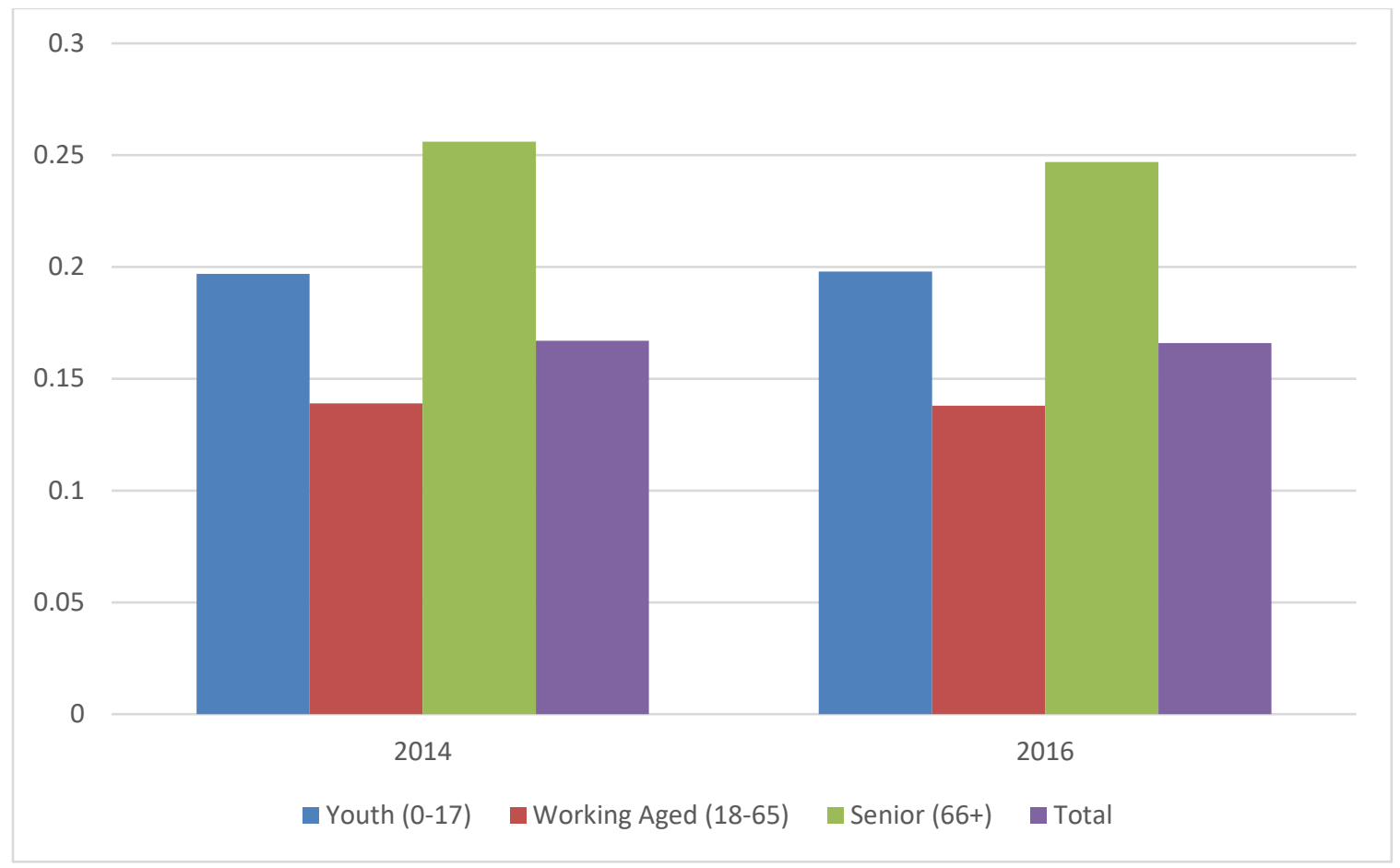

Source: OECD Poverty Rates and author calculations.

Poverty rates are not the only useful indicator when investigating poverty. The introduction of the new multi-dimensional poverty measure by CONEVAL $^{182}$ in 2008 makes comparisons of poverty over time prior to 2009 difficult to interpret. For this reason, as well as the availability of comparable data, the following analysis is restricted to the period 2010 to 2016, with the latter being the most recent period for which this information is available.

In 2016, 53.4 million and 9.4 million people lived in poverty and extreme poverty, respectively. In other words, just under half (43\%) of the population of Mexico live in poverty while $7.6 \%$ live in extreme poverty. Over the period of interest, poverty grew $1.3 \%$ with growth

182 "Medición de la pobreza," CONEVAL, last modified 2018, https://www.coneval.org.mx/Medicion/MP/Paginas/Lineamientos_DOF.aspx. 
concentrated from 2010-2014 and a slight decrease (3.5\%) between 2014 and 2016. This growth coincides with a decrease in the number of individuals in extreme poverty of $27.6 \%$ in the same period (see Table 2).

An important factor in the choice of Oaxaca as a case study was the large Indigenous population. In 2015 (the last period for which this information was available) Oaxaca had the largest Indigenous population of any state in Mexico at $14.4 \%$ of the national Indigenous population and $43.7 \%$ of the state population. ${ }^{183}$ Oaxaca also had the fifth largest state population in poverty in 2016: 2.8 million individuals lived in poverty, making up $70.4 \%$ of the state population. ${ }^{184}$ The concentration of extreme poverty in Oaxaca is even deeper at $26.9 \%$ (1.1 million individuals) of the population putting Oaxaca in second place. To put this into perspective, at the time of the last census in 2010, Oaxaca accounted for $3.4 \%{ }^{185}$ of Mexico's population but in 2016 accounted for $4.9 \%$ of individuals in poverty and $8.7 \%$ of those in extreme poverty (see Table 2). ${ }^{186}$

${ }^{183}$ Indicadores socioeconómicos de los pueblos indígena de México, 2015, 11.

${ }^{184}$ Medición de la pobreza, Estados Unidos Mexicanos, 2016: Porcentaje, número de personas y carencias promedia por indicador de pobreza, según entidad federativa, 2010-2016, and author calculations.

185 "Población total por Entidad federativa, Grupo quinquenal de edad, Periodo y Sexo.

${ }^{186}$ Medición de la pobreza, Estados Unidos Mexicanos, 2016: Porcentaje, número de personas y carencias promedia por indicador de pobreza, según entidad federativa, 2010-2016, and author calculations. 
Table 2: Poverty and Extreme Poverty in Mexico and Oaxaca (millions), 2010-2016 187

\begin{tabular}{|c|c|c|c|c|c|}
\hline & & 2010 & 2012 & 2014 & 2016 \\
\hline \multirow{6}{*}{ Oaxaca } & Poverty & 2,596 & 2,435 & 2,663 & 2,847 \\
\hline & Proportion & $67.0 \%$ & $61.9 \%$ & $66.8 \%$ & $70.4 \%$ \\
\hline & Growth & & $-6.2 \%$ & $9.4 \%$ & $6.9 \%$ \\
\hline & Extreme Poverty & 1,133 & 917 & 1,130 & 1,087 \\
\hline & Proportion & $29 \%$ & $23 \%$ & $28 \%$ & $27 \%$ \\
\hline & Growth & & $-19 \%$ & $23 \%$ & $-4 \%$ \\
\hline \multirow{6}{*}{ Mexico } & Poverty & 52,813 & 53,350 & 55,342 & 53,418 \\
\hline & Proportion & $46 \%$ & $45 \%$ & $46 \%$ & $44 \%$ \\
\hline & Growth & & $1 \%$ & $4 \%$ & $-3 \%$ \\
\hline & Extreme Poverty & 12,965 & 11,529 & 11,442 & 9,376 \\
\hline & Proportion & $11.3 \%$ & $9.8 \%$ & $9.5 \%$ & $7.6 \%$ \\
\hline & Growth & & $-11 \%$ & $-1 \%$ & $-18 \%$ \\
\hline
\end{tabular}

Source: "Medición de la pobreza," CONEVAL and author calculations.

It is therefore clear that poverty has not been eliminated in Oaxaca. Rather, in relation to Mexico as a whole poverty has increased both in absolute and percentage terms. It is important to note that there has been a modest improvement to extreme poverty levels in Oaxaca. However, this improvement is not nearly as significant as improvements to extreme poverty levels at the national level.

While it is hard to discern causes of poverty at the subnational level in Mexico (much of the analysis and data are available only at the national level), there are some defining historical structures which reinforce systemic inequality and oppression in the state. Governance in Oaxaca, dominated by PRI governments, functions as an essentially authoritarian regime. ${ }^{188}$ Many local governments in Oaxaca function based on 'Indigenous' customs and traditions that are used by some wings of the PRI to maintain their electoral dominance. ${ }^{189}$ More than half (53\%) of Oaxacan

${ }^{187}$ Medición de la pobreza, Estados Unidos Mexicanos, 2016: Porcentaje, número de personas y carencias promedia por indicador de pobreza, según entidad federativa, 2010-2016, and author calculations.

${ }^{188}$ Mills, The Limits of Trust, 143.

${ }^{189}$ Bartra, The Mexican Transition, 131. 
populations live in rural areas and overall the state is highly fragmented territorially, economically, and politically. ${ }^{190}$ Furthermore, as Mills notes, “Oaxaca is highly dependent on federal government transfers: more than 90 per cent of its revenues come from the federation." ${ }^{191}$ As I have previously mentioned, Indigenous peoples are over-represented in Oaxaca and in the Program (discussed in section 4.4.1). The historic treatment of Indigenous peoples in this state - including traditional land exploitation and displacement in favour of business interests ${ }^{192}$ - leaves these populations particularly vulnerable to poverty.

\subsection{Characterizing the poor}

In this section I discuss the sociodemographic results of program recipients in Oaxaca. As previously mentioned, the data herein is derived from two data sources: one at the household level and the other at the individual level. While the data are divided in this manner, the analysis that follows is organized into topics during that I indicate which dataset the information is derived from should the need arise. These topics are: household composition, dwelling characteristics, nutrition, education, labour market characteristics and household expenditures.

These categories will first be analyzed at the general level then with considerations of indigeneity. One limitation of doing analysis on two separate datasets is the inability to link individual demographic information to households. This is pertinent to discussion of indigeneity as the variable which identifies Indigenous ancestry is present only in the individual level data therefore eliminating the possibility of analysis the impacts of indigeneity on outcomes at the household level.

\footnotetext{
${ }^{190}$ Mills, The Limits of Trust, 145.

${ }^{191}$ Mills, The Limits of Trust, 145.

${ }^{192}$ Mills, The Limits of Trust, 147.
} 


\subsubsection{Household composition}

One of the first thoughts that comes to mind when thinking generally about developing nations and poverty is family size. While there is not necessarily any causal relationship between the two, larger families do mean finite resources must be spread across a larger number of individuals. The average family size of beneficiary households declined slightly between 2011 and 2014 from just 3.8 to 2.6. This decline was due mostly to the decline in large households (with five or more members) and to gains in households of two individuals (see Figure 4). In other words, there was a redistribution of family sizes amongst recipients such that the average family size decreased.

It is hard to say why this occurred. It could be that required health education for titulares or forced tubal litigations (as mentioned in my literature review) had an impact over the long-term, meaning newly eligible families had fewer children. It is also possible that a deepening of poverty in Oaxaca made more small-sized families eligible for the Program. Unfortunately, without further information it is impossible to definitively give a reason for the decrease in average family amongst recipients. 
Figure 4: Beneficiary Family Size, 2011-2017

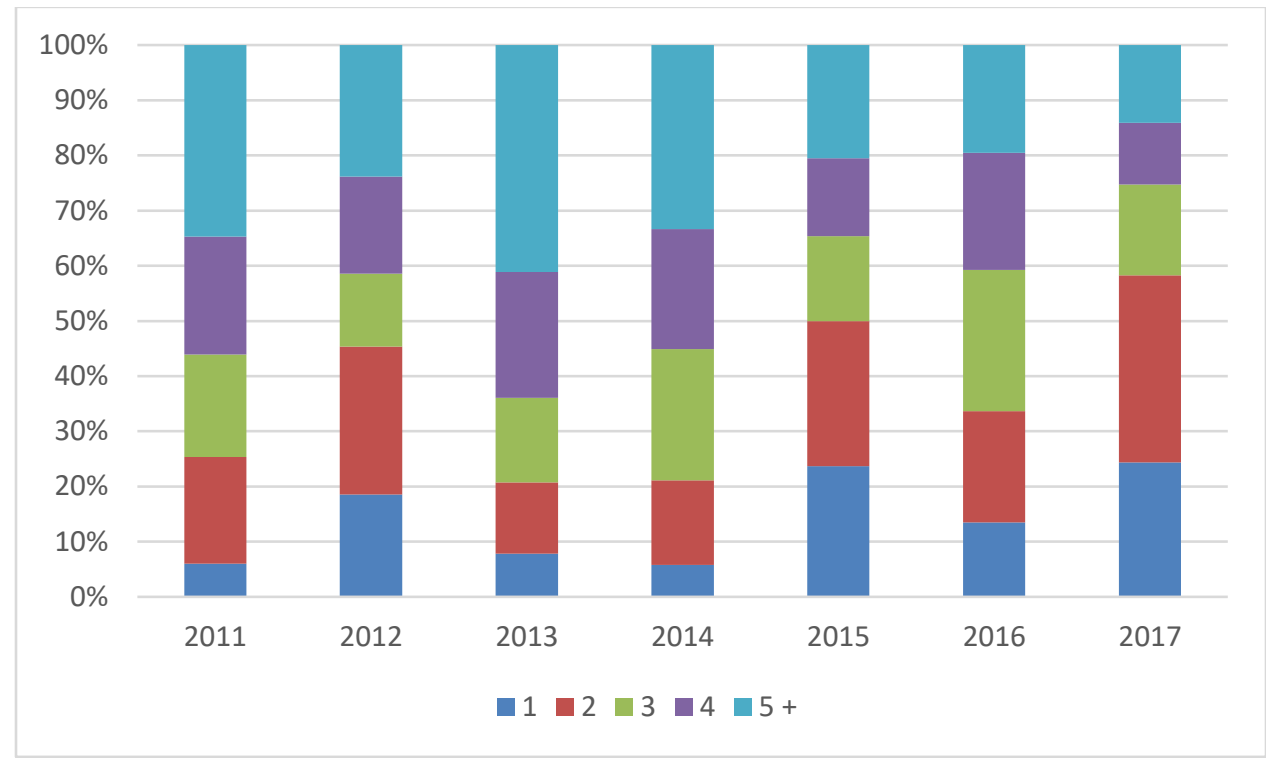

\subsubsection{Dwelling characteristics}

The characteristics of a dwelling can be indicative of the conditions faced by families in poverty. While these characteristics can be revealing, it should be noted that housing in rural and urban areas may tend to have different characteristics that cannot be accounted for in this analysis. For example, apartment buildings are more often features of urban settings and housing on family land is more likely to be in a rural setting.

While most beneficiaries owned or had fully paid for their homes from 2011-2017, the share of full ownership decreased from $74 \%$ in 2011 to $70 \%$ in 2017 . The decrease in the share of beneficiaries fully owning their home was mostly due to the increase in the share of those borrowing or maintaining homes for others, which rose from $20 \%$ in 2011 to $24 \%$ in 2017 . The remaining difference is comprised of small increases in the share of rented or leased homes $(4 \%$ 
in 2011 compared to $5 \%$ in 2017) and the proportion of beneficiaries whose homes were intested ${ }^{193}$ or subject to litigation $(0.2 \%$ in 2011 compared to $1 \%$ in 2017$)$.

Table 3: Beneficiary Housing Ownership, 2011-2017

\begin{tabular}{|l|r|r|r|r|r|r|r|}
\hline & 2011 & 2012 & 2013 & 2014 & 2015 & 2016 & 2017 \\
\hline Owned and fully paid & $74 \%$ & $77 \%$ & $65 \%$ & $65 \%$ & $67 \%$ & $57 \%$ & $70 \%$ \\
\hline Own and being paid & $1 \%$ & $1 \%$ & $3 \%$ & $1 \%$ & $0.0 \%$ & $1 \%$ & $1 \%$ \\
\hline Owned and mortgaged & $0.1 \%$ & $0.0 \%$ & $0.0 \%$ & $0.0 \%$ & $0.0 \%$ & $0.0 \%$ & $0.0 \%$ \\
\hline Rented or leased & $4 \%$ & $2 \%$ & $3 \%$ & $8 \%$ & $1 \%$ & $6 \%$ & $5 \%$ \\
\hline Borrowed or maintaining for another individual & $20 \%$ & $20 \%$ & $26 \%$ & $25 \%$ & $31 \%$ & $36 \%$ & $24 \%$ \\
\hline Intested or subject to litigation & $0.2 \%$ & $0.2 \%$ & $3 \%$ & $1 \%$ & $1 \%$ & $1 \%$ & $1 \%$ \\
\hline
\end{tabular}

The vast majority of beneficiary households lived in detached housing from 2011-2017 (see Table 4). In 2017 89\% of recipient households lived in this form of housing, up from $83 \%$ in 2011. This increase is mostly explained by decreases to housing on shared family land during the period which decreased from $14 \% 2011$ to $6 \%$ in 2017 . In $201770 \%$ of beneficiary households owned a household that was fully paid, a decrease of four percent over the period from 2011-2017. This was offset by gains to the percentage of recipient households borrowing or maintaining dwellings for a third party.

Table 4: Beneficiary Housing Types, 2011-2017

\begin{tabular}{|l|r|r|r|r|r|r|r|}
\hline & 2011 & 2012 & 2013 & 2014 & 2015 & 2016 & 2017 \\
\hline Detached house & $83 \%$ & $87 \%$ & $86 \%$ & $78 \%$ & $77 \%$ & $80 \%$ & $89 \%$ \\
\hline Apartment building/Housing Unit & $0.0 \%$ & $0.0 \%$ & $0.0 \%$ & $0.0 \%$ & $0.0 \%$ & $0.0 \%$ & $0.2 \%$ \\
\hline Housing or room in neighbourhood & $2 \%$ & $0.4 \%$ & $0.3 \%$ & $3 \%$ & $2 \%$ & $2 \%$ & $4 \%$ \\
\hline Housing or room upper floor & $0.2 \%$ & $0.0 \%$ & $0.0 \%$ & $0.0 \%$ & $0.0 \%$ & $0.4 \%$ & $0.2 \%$ \\
\hline Annex to house & $1 \%$ & $0.4 \%$ & $0.0 \%$ & $1 \%$ & $0 \%$ & $1 \%$ & $0.0 \%$ \\
\hline Housing on shared family land & $14 \%$ & $12 \%$ & $14 \%$ & $18 \%$ & $21 \%$ & $16 \%$ & $6 \%$ \\
\hline
\end{tabular}

\footnotetext{
${ }^{193}$ Referring to the process of determining the inheritance of assets when an owner dies without a legally binding will.
} 
Another important consideration when assessing the impact of the Program on poverty as indicated by dwelling characteristics is the construction of the dwelling and access to household amenities. From 2011 to 2017 the proportion of beneficiary households in which families did not have separate rooms for cooking and sleeping increased from $83 \%$ in 2011 to $87 \%$ in 2017 . This increase can be interpreted in several ways. The sample from which this information was collected decreased from 1,212 in 2011 to 419 in 2017. This could be the result of fewer families qualifying for the Program therefore those remaining are increasingly impoverished.

Figure 5: Same Room for Cooking and Sleeping, 2011-2017

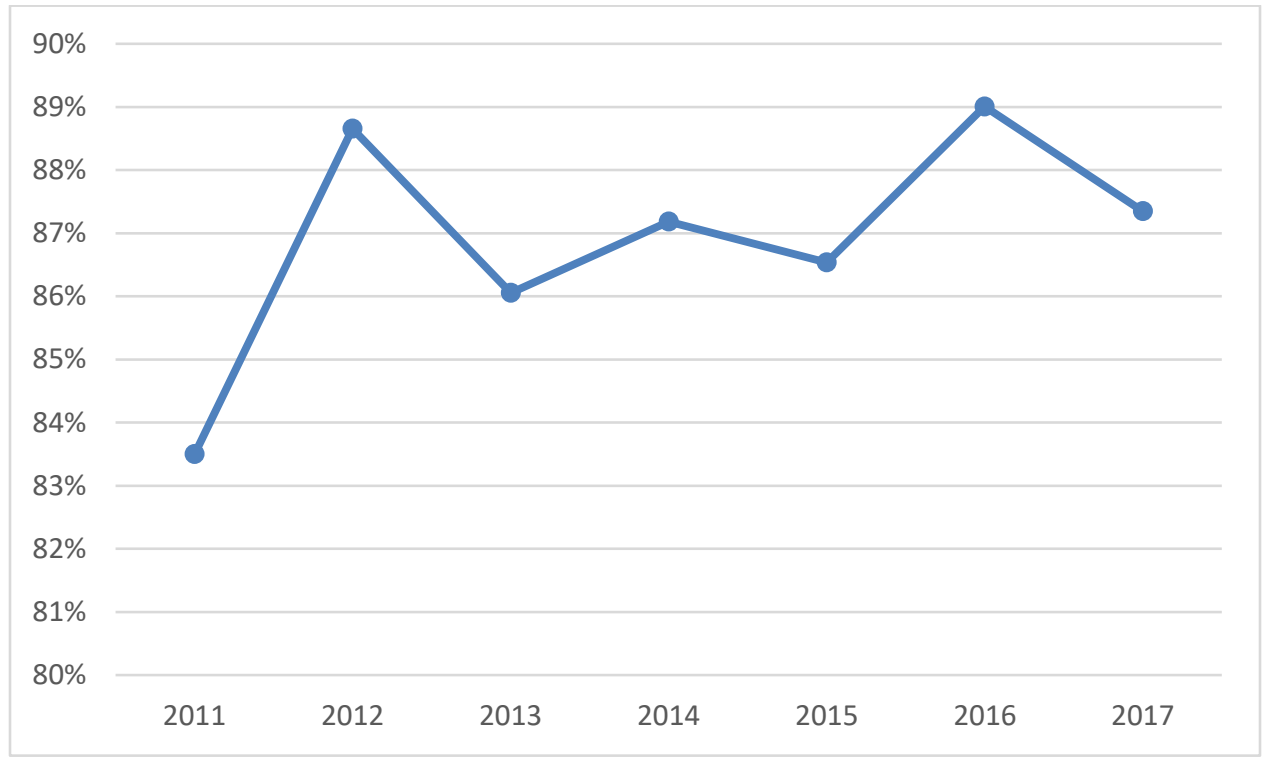

The materials from which the floor and roof of a dwelling are constructed and/or maintained provides further insight to the characteristics of households in poverty. While some fluctuations occur over the period, dwelling flooring material of beneficiary households remained largely unchanged from 2011 to 2017 (see Table 5). Over this period the vast majority (around $80 \%$ ) had floors of cement or asphalt. The decrease of $1 \%$ seen in mosaic, wood or other material flooring was offset by the increase of the same magnitude to flooring consisting only of earth. The 
slight increase in the proportion of beneficiaries with flooring comprised only of earth should be analyzed with the same attention to different possibilities as discussed under the increasing proportion of households sleeping and cooking in a single room with a further consideration.

It is possible that this increase is the result of deepening poverty as the value of grants decreased in comparison to the cost of living for beneficiaries (i.e. the value of the benefit not keeping pace with increases to the cost of living). It could also be due to the decreasing sample size from 2011 to 2017 which, in this case, can be interpreted in two ways. The first, as in the case with sleeping and cooking household accommodations, is that the sample reflects fewer families qualifying for the Program. However, given the differences in dwellings between urban and rural settings, it is possible that this increase reflects an intensification in poverty in rural regions of Oaxaca. Given that $90 \%$ of beneficiaries in Oaxaca reported being of Indigenous descent in $2017^{194}$ and $62 \%$ of Indigenous peoples in Mexico reported living in rural locations in $2010^{195}$, this seems highly plausible.

Table 5: Dwelling Flooring Material, 2011-2017

\begin{tabular}{|l|r|r|r|r|r|r|r|}
\hline & 2011 & 2012 & 2013 & 2014 & 2015 & 2016 & 2017 \\
\hline Earth & $16 \%$ & $15 \%$ & $13 \%$ & $10 \%$ & $16 \%$ & $15 \%$ & $17 \%$ \\
\hline Cement or asphalt & $80 \%$ & $82 \%$ & $83 \%$ & $83 \%$ & $79 \%$ & $78 \%$ & $80 \%$ \\
\hline Mosaic, wood, or other material & $4 \%$ & $4 \%$ & $4 \%$ & $8 \%$ & $4 \%$ & $7 \%$ & $3 \%$ \\
\hline
\end{tabular}

Much the same logic can be applied to changes in roofing materials of beneficiary dwellings from 2011 to 2017. A significant increase in metallic panels as roofing (from $44 \%$ to $60 \%$ ) is explained by a nearly proportional decrease in dwellings using concrete slabs or bricks

\footnotetext{
194 Discussed in next section.

${ }^{195}$ La población indígena en al México rural: situación actual y perspectivas (Mexico City: Gobierno de México -Centro de Estudios para el Desarrollo Rural Sustentable y la Soberanía Alimentaria, 2015), 6.
} 
with beams as roofing (from $38 \%$ in 2011 to $29 \%$ ). It could be suggested that metallic panelling (being associated with semi-detached or detached housing) is more likely to be prevalent in rural settings, thus indicating an intensification of rural poverty over the period 2011-2017.

Table 6: Dwelling Roofing Material, 2011-2017

\begin{tabular}{|l|r|r|r|r|r|r|r|}
\hline & 2011 & 2012 & 2013 & 2014 & 2015 & 2016 & 2017 \\
\hline Waste material (cardboard, rubber, fabric, tires, etc.) & $2 \%$ & $2 \%$ & $3 \%$ & $1 \%$ & $0 \%$ & $1 \%$ & $1 \%$ \\
\hline Cardboard panels & $1 \%$ & $0.4 \%$ & $1 \%$ & $0.0 \%$ & $0.0 \%$ & $0.4 \%$ & $0.5 \%$ \\
\hline Metallic panels & $44 \%$ & $46 \%$ & $45 \%$ & $33 \%$ & $48 \%$ & $50 \%$ & $60 \%$ \\
\hline Asbestos panels & $6 \%$ & $5 \%$ & $4 \%$ & $8 \%$ & $3 \%$ & $4 \%$ & $5 \%$ \\
\hline Palm or straw & $1 \%$ & $2 \%$ & $0.0 \%$ & $1 \%$ & $0.0 \%$ & $0.4 \%$ & $2 \%$ \\
\hline Wood or shingle & $0.2 \%$ & $0.2 \%$ & $0.0 \%$ & $0.0 \%$ & $1 \%$ & $0.0 \%$ & $0.0 \%$ \\
\hline Flat roof with beams & $0.0 \%$ & $0.2 \%$ & $0.0 \%$ & $0.0 \%$ & $0.0 \%$ & $0.4 \%$ & $0.2 \%$ \\
\hline Tile & $8 \%$ & $8 \%$ & $3 \%$ & $6 \%$ & $9 \%$ & $4 \%$ & $2 \%$ \\
\hline Concrete slabs or bricks with beams & $38 \%$ & $36 \%$ & $44 \%$ & $51 \%$ & $40 \%$ & $41 \%$ & $29 \%$ \\
\hline
\end{tabular}

Since 2011 the proportion of households without washrooms has modestly decreased from 2\% in 2011 to $1 \%$ in 2017 (see Table 7), indicating some improvement to the living conditions of recipients. This improvement is not reflected in dwelling access to water which saw a decrease of 9\% to running water inside recipient dwellings (see Table 8 ) over the same period.

Table 7: Dwelling Including Washroom, 2011-2017

\begin{tabular}{|l|r|r|r|r|r|r|r|}
\hline & 2011 & 2012 & 2013 & 2014 & 2015 & 2016 & 2017 \\
\hline With water connection/with direct water discharge & $13 \%$ & $15 \%$ & $12 \%$ & $17 \%$ & $11 \%$ & $11 \%$ & $12 \%$ \\
\hline Water loaded using bucket & $57 \%$ & $35 \%$ & $48 \%$ & $71 \%$ & $49 \%$ & $57 \%$ & $53 \%$ \\
\hline No water connection (dry or wet latrine) & $22 \%$ & $40 \%$ & $37 \%$ & $9 \%$ & $24 \%$ & $30 \%$ & $29 \%$ \\
\hline Well or dug latrine & $7 \%$ & $8 \%$ & $1 \%$ & $1 \%$ & $16 \%$ & $2 \%$ & $6 \%$ \\
\hline None & $2 \%$ & $3 \%$ & $2 \%$ & $1 \%$ & $1 \%$ & $0.0 \%$ & $1 \%$ \\
\hline
\end{tabular}


Table 8: Dwelling Access to Water, 2011-2017

\begin{tabular}{|l|r|r|r|r|r|r|r|}
\hline & 2011 & 2012 & 2013 & 2014 & 2015 & 2016 & 2017 \\
\hline Running water inside dwelling & $23 \%$ & $26 \%$ & $14 \%$ & $22 \%$ & $17 \%$ & $15 \%$ & $14 \%$ \\
\hline Running water outside dwelling but on premises & $53 \%$ & $42 \%$ & $48 \%$ & $64 \%$ & $57 \%$ & $59 \%$ & $60 \%$ \\
\hline Running water from public tap & $2 \%$ & $0.2 \%$ & $3 \%$ & $3 \%$ & $3 \%$ & $6 \%$ & $5 \%$ \\
\hline Running water from another dwelling & $2 \%$ & $2 \%$ & $0.3 \%$ & $0.0 \%$ & $0.0 \%$ & $1 \%$ & $0.5 \%$ \\
\hline Water transported by truck & $9 \%$ & $4 \%$ & $20 \%$ & $1 \%$ & $3 \%$ & $7 \%$ & $7 \%$ \\
\hline Water from a well, river, lake, stream or other source & $11 \%$ & $19 \%$ & $14 \%$ & $10 \%$ & $19 \%$ & $12 \%$ & $11 \%$ \\
\hline Water collected from rain or other means & $0.3 \%$ & $6 \%$ & $0.0 \%$ & $0.0 \%$ & $1 \%$ & $0.0 \%$ & $1 \%$ \\
\hline
\end{tabular}

Recipient household mobility decreased from 2011-2017 as indicated by a 3\% increase to the proportion of households without access to cars. This is especially important given the aforementioned relatively high proportion of recipients in rural areas who are more likely to need cars to travel to service locations in order to meet the conditionality requirements of the Program.

Table 9: Household Access to Car, 2011-2017

\begin{tabular}{|l|r|r|r|r|r|r|r|}
\hline & 2011 & 2012 & 2013 & 2014 & 2015 & 2016 & 2017 \\
\hline Have and use & $6 \%$ & $7 \%$ & $4 \%$ & $11 \%$ & $4 \%$ & $3 \%$ & $4 \%$ \\
\hline Have and don't use & $2 \%$ & $5 \%$ & $0 \%$ & $0 \%$ & $0 \%$ & $1 \%$ & $1 \%$ \\
\hline Don't have & $93 \%$ & $88 \%$ & $95 \%$ & $89 \%$ & $96 \%$ & $96 \%$ & $96 \%$ \\
\hline
\end{tabular}

\subsection{Social and economic outcomes}

\subsubsection{Beneficiary minority status}

As I mentioned in the Data and sample section of this chapter, sample size has posed some issues to the analysis of ENCASEH data. This is especially true for minority status. While Indigenous recipients make up a substantial portion of the Oaxaca sample overall, the sample for this state is relatively small already. However, the proportion of recipients who report being of Indigenous descent increased from $81 \%$ in 2012 to $90 \%$ in 2017. The concentration of Indigenous recipients jumps from $81 \%$ in 2014 to $92 \%$ in 2015 . This could reflect changes to the eligibility criteria introduced in 2014 when the Program changed from the previous Oportunidades version 
to the current version, Prospera. However, without further information from the evaluation data it is hard to say definitively whether this is the case. For example, it is possible that the jump is due to sampling error or changes to the survey program and its administration. This increase is also observed in the other minority group captured by this survey program, Afro-Mexicans. It should be noted that the total for Indigenous, Afro-Mexican and Partially Afro-Mexican exceeds $100 \%$ in 2017. This would indicate that there is some overlap between those reporting Indigenous descent and Partially Afro-Mexican descent. In other words, survey respondents would have been able to answer yes to both questions on minority descent.

Table 10: Beneficiary Minority Status, 2011-2017

\begin{tabular}{|l|r|r|r|r|r|r|}
\hline & 2012 & 2013 & 2014 & 2015 & 2016 & 2017 \\
\hline Indigenous & $81 \%$ & $79 \%$ & $81 \%$ & $92 \%$ & $92 \%$ & $90 \%$ \\
\hline Afro-Mexican & \multicolumn{7}{|l|}{} & & $7 \%$ & $10 \%$ \\
\hline Partially Afro-Mexican & \multicolumn{1}{|l|}{} & & $1 \%$ & $6 \%$ \\
\hline
\end{tabular}

Table 11: Languages Spoken by Beneficiary, 2011-2017

\begin{tabular}{|l|r|r|r|r|r|r|r|}
\hline & 2011 & 2012 & 2013 & 2014 & 2015 & 2016 & 2017 \\
\hline Indigenous Language & $88 \%$ & $77 \%$ & $83 \%$ & $79 \%$ & $70 \%$ & $82 \%$ & $80 \%$ \\
\hline Spanish & $95 \%$ & $91 \%$ & $96 \%$ & $96 \%$ & $93 \%$ & $90 \%$ & $94 \%$ \\
\hline
\end{tabular}

Of those reporting Indigenous descent, speakers of Indigenous languages declined from $88 \%$ in 2011 to $80 \%$ in 2012 . Over the same period the same groups reported a slight decrease in Spanish speaking capacity, likely due to an increase in unilingual long-term Indigenous recipients over time. These trends must be understood in a post-colonial context in which the Program is used as a mechanism by the Mexican state to assimilate those of Indigenous ancestry. While education is a key tenet of the Program, provision of education in Indigenous languages and Indigenous language rights are not. The result of the Program's conditionalities is an increase in the number of children with access to Spanish-only instruction, decreasing the likelihood of this 
generation learning Indigenous languages, while at the same time providing no Spanish-language support to those who speak only Indigenous languages.

\subsubsection{Nutrition}

\subsubsection{Meals and nutritional expenditure}

Unfortunately, there are no clear trends in relation to meals eaten per day (see Figure 6) or monthly nutritional expenditure (see Figure 7). However, the pattern of these variables has coincided with recessions in Mexico as reflected by OECD recession indicators during 2013-2014 and 2017-present. ${ }^{196}$ Indeed recipients indicating they ate two meals per day increased at the expense of those eating 3 meals per day in 2014. Moreover, decreased spending on nutrition in 2014 and 2016 might reflect decrease in available resources for recipients during these times. Given the movement of these indicators in line with recessional indicators suggest recipients are vulnerable to economic shocks. This supports my argument that the Program has been used to mitigate the hardships associated with crises in the capitalist system but that it cannot adequately do so.

196 “OECD based Recession Indicators for Mexico from the Period following the Peak through the Trough,” Federal Reserve Bank of St. Louis (FRED), Last modified Dec. 9, 2019, https://fred.stlouisfed.org/series/MEXRECD. 
Figure 6: Usual Number of Meals Consumed per day in Household, 2011-2017

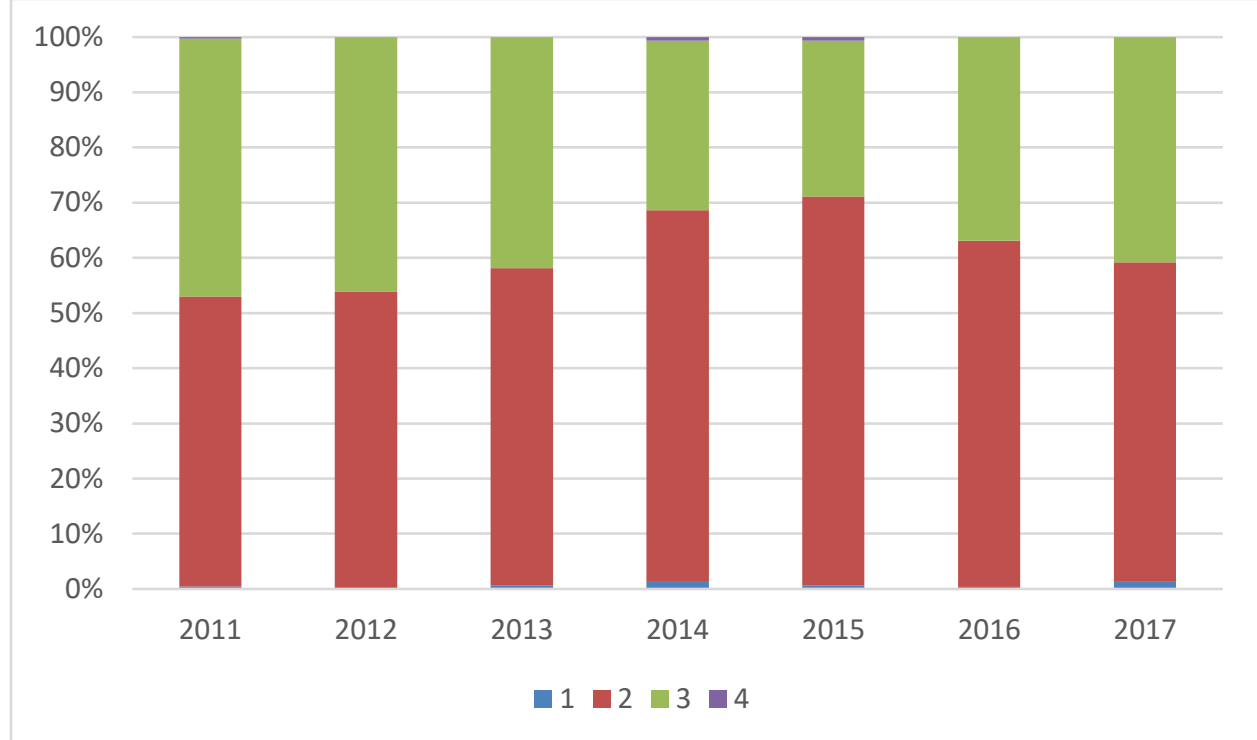

Figure 7: Monthly Household Nutritional Expenditure

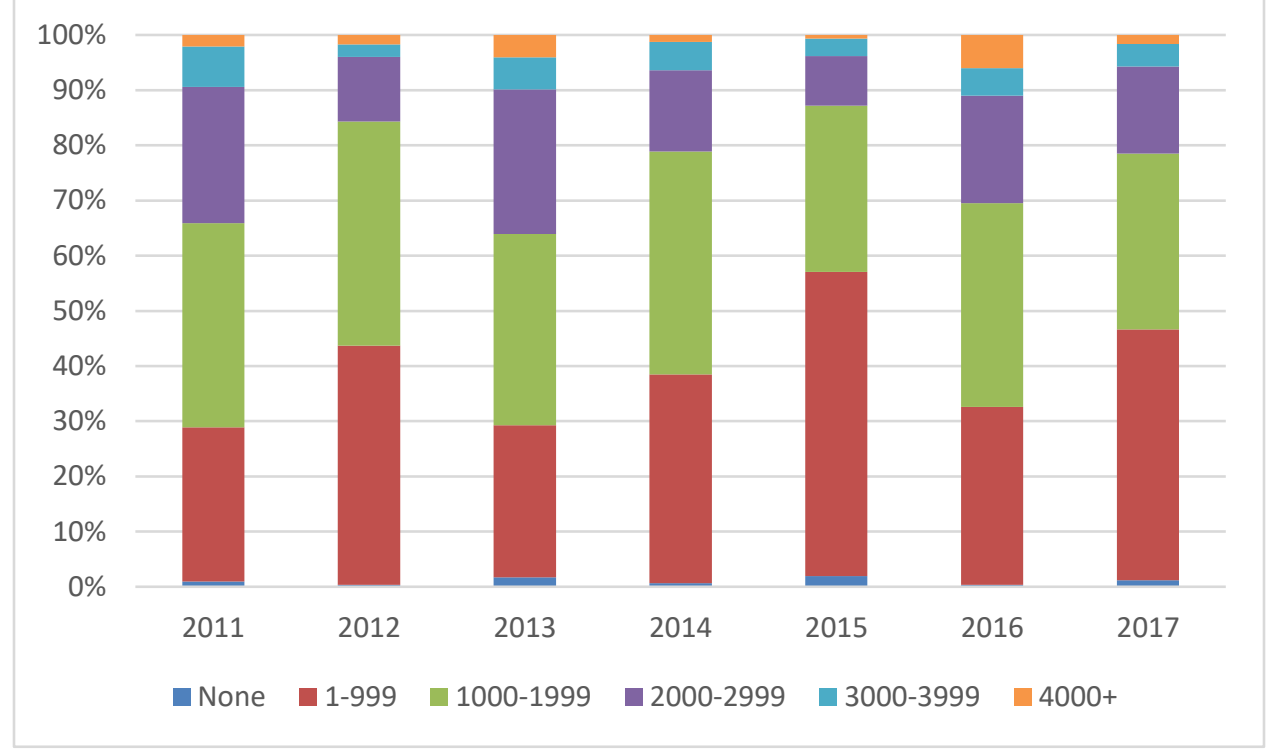

\subsubsection{Food Security}

The Program effects on recipients eating one or less meals per day has seen drastic improvement for adults with much more modest improvement for children, as reported by their recipient parents (see Figure 8). As one of the key tenets of the Program, human capital investment in the form of improved nutrition in children has not been significantly realized. Therefore, the 
more drastic improvement for adults should be interpreted with caution. It is possible that previously adults were forgoing nutritional intake in favour of their children, indicating that the Program has allowed adults to improve their nutritional intake to basic levels rather than the achievement of appropriate levels. This logic can also be applied to Table 12 which shows the proportion of recipients who were hungry but didn't eat. The drastic improvement for adults is not mirrored for children which may show more of a reallocation of resources than true improvements to food security.

Figure 8: Households Where One or Fewer Meals was Eaten in a Day, 2011-2017

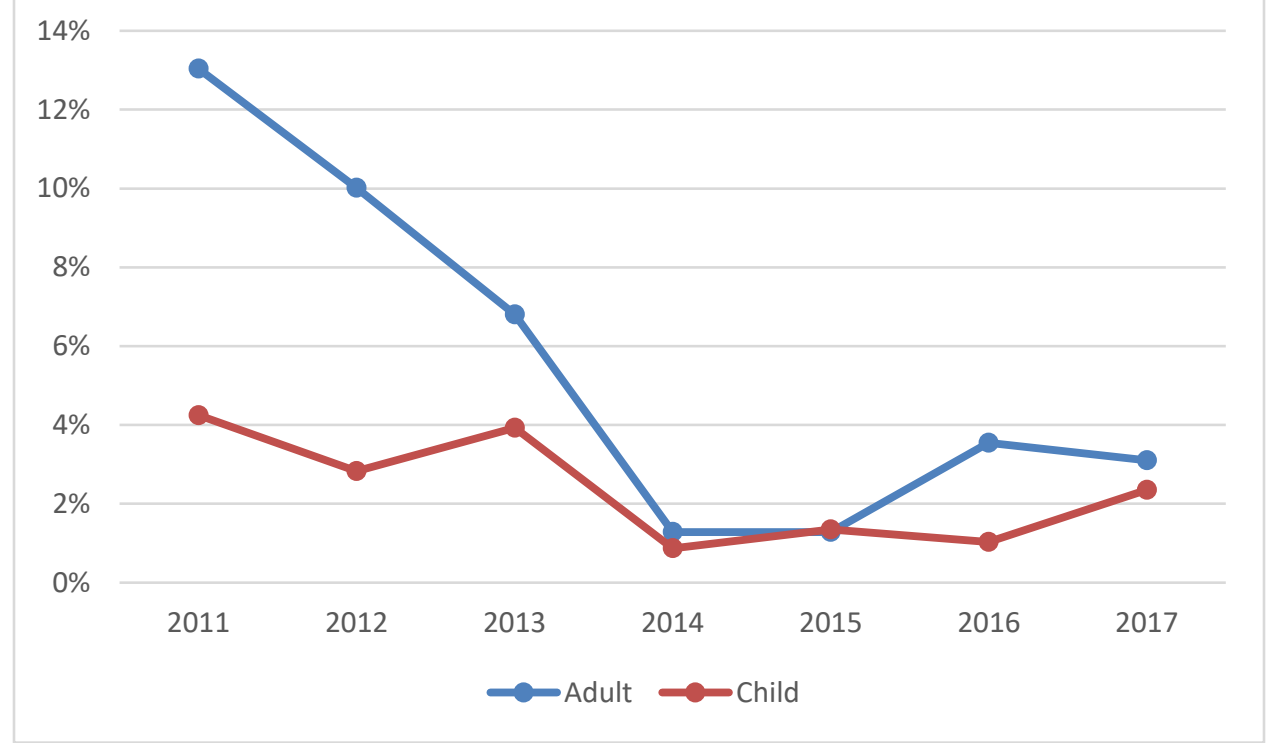

Table 12: Households Where Members were Hungry but didn't Eat, 2011-2017

\begin{tabular}{|l|r|r|r|r|r|r|r|}
\hline & 2011 & 2012 & 2013 & 2014 & 2015 & 2016 & 2017 \\
\hline Adult & $7 \%$ & $4 \%$ & $7 \%$ & $1 \%$ & $1 \%$ & $6 \%$ & $2 \%$ \\
\hline Child & $4 \%$ & $2 \%$ & $7 \%$ & $0 \%$ & $1 \%$ & $4 \%$ & $1 \%$ \\
\hline
\end{tabular}

Much like the previous general section on nutrition, the trend for households where an adult ran out of food aligns closely with a positive recession indicator in Mexico. While this question is not asked of children, this would indicate that in times of recession when resources are 
scarce parents forgo meals to conserve food for their children. This provides further support for my argument that the Program has not created a sufficient safety net for recipients such that they are lifted out of poverty and are not vulnerable to economic downturns.

Figure 9: Households Where an Adult Ran out of Food, 2011-2017

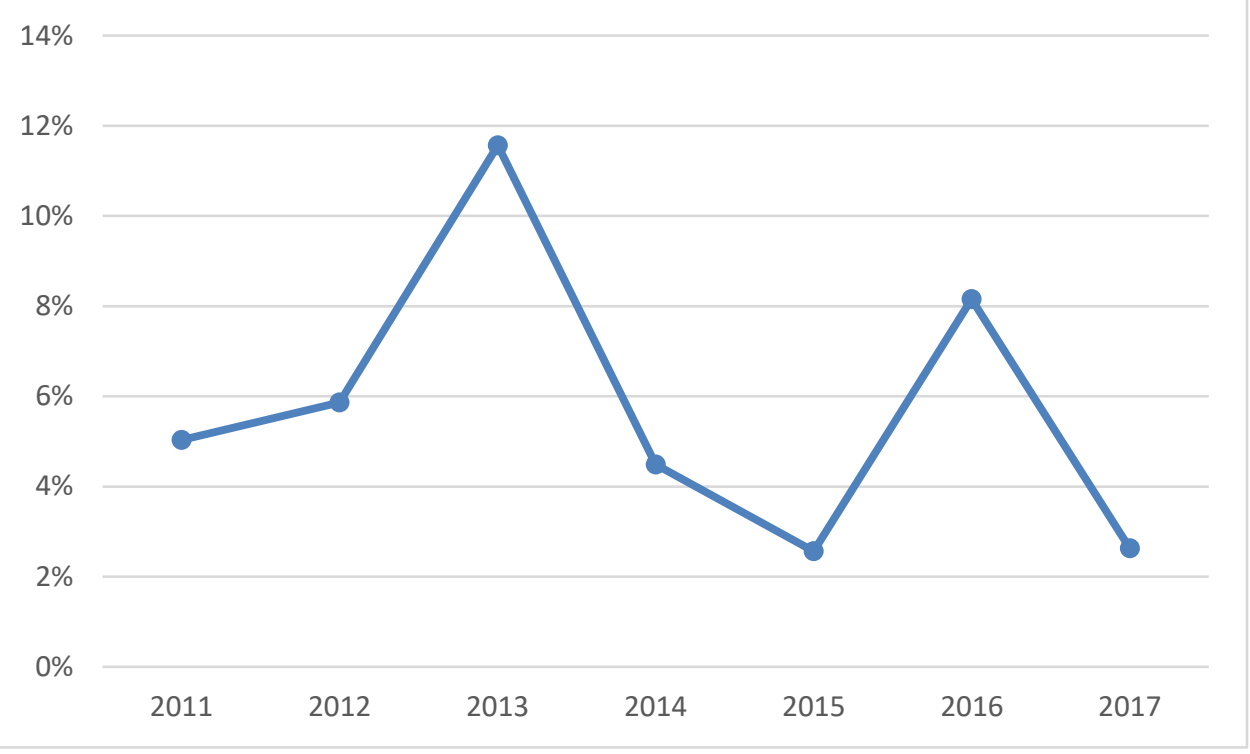

\subsubsection{Health and Education}

Of the other key areas targeted by the Program, questions about health outcomes are the area where survey data provides the least relevant information. The only variable which would specifically target health outcomes for long-term recipients is access to healthcare. ${ }^{197}$ This being the case, there have been improvements to healthcare access for long-term recipients from 20112017. The proportion of those who receive healthcare through government provision has increased $12 \%$ over the period of interest. This increase is partially offset by a modest decrease in recipients using private hospitals or offices.

197 There are many questions related to the health of beneficiaries, however they concern pre-existing conditions (such as disabilities) therefore the results would be more indicative of reasons for requiring social assistance than outcomes related to interventions by the Program itself. 
Table 13: Household Access to Healthcare, 2011-2017

\begin{tabular}{|l|r|r|r|r|r|r|r|}
\hline & 2011 & 2012 & 2013 & 2014 & 2015 & 2016 & 2017 \\
\hline $\begin{array}{l}\text { Government Provision } \\
\text { (Federal, Military \& } \\
\text { Defense, State) }\end{array}$ & $85 \%$ & $92 \%$ & $89 \%$ & $97 \%$ & $97 \%$ & $96 \%$ & $97 \%$ \\
\hline Private hospital or office & $4 \%$ & $2 \%$ & $2 \%$ & $1 \%$ & $2 \%$ & $0.3 \%$ & $1 \%$ \\
\hline Pharmacist consultation & $1 \%$ & $0.2 \%$ & $1 \%$ & $1 \%$ & $1 \%$ & $4 \%$ & $2 \%$ \\
\hline $\begin{array}{l}\text { Traditional medicine } \\
\text { provider (homeopathic, } \\
\text { midwife, shaman) }\end{array}$ & $1 \%$ & $1 \%$ & $0.0 \%$ & $0.2 \%$ & $0.0 \%$ & $0.0 \%$ & $0.1 \%$ \\
\hline Self-treatment & $0.0 \%$ & $0.0 \%$ & $5 \%$ & $0.3 \%$ & $0.0 \%$ & $0.1 \%$ & $0.0 \%$ \\
\hline Other & $4 \%$ & $2 \%$ & $4 \%$ & $0.2 \%$ & $0.4 \%$ & $0.0 \%$ & $0.0 \%$ \\
\hline Doesn't seek treatment & $5 \%$ & $3 \%$ & $0.0 \%$ & $0.2 \%$ & $0.0 \%$ & $0.3 \%$ & $1 \%$ \\
\hline
\end{tabular}

Moreover, the proportion of recipients who do not seek treatment have declined by $4 \%$ over the same period. Unfortunately, ENCASEH does not capture any data on the quality of care provided through the Program. Therefore, it is hard to say if the increase in beneficiaries accessing healthcare through government provision is due to improvements to its quality or rather an inability to afford private healthcare. Similarly, the decrease in those forgoing treatments for illness could be due many factors that cannot be accounted for in this data.

Basic literacy - as measured through beneficiary ability to read and write a message - has not followed a particular trend over this time (see Figure 10) This could be due to the fact that human capital investment through the Program is targeted at children and therefore not reflected in adults. 
Figure 10: Beneficiaries who can Read and Write a Message, 2011-2017

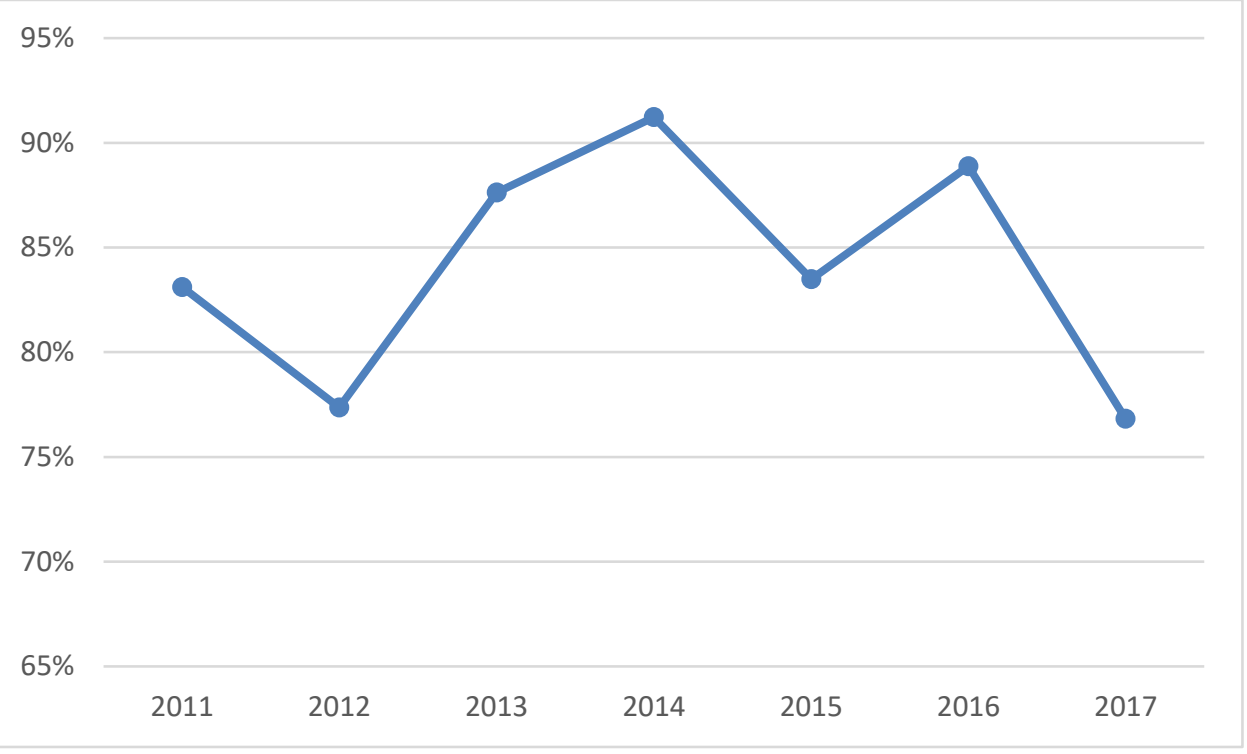

Table 14 presents the education levels of Program beneficiaries. On the whole, most levels of education saw decreases for long-term recipients. While this trend would indicate that a smaller concentration of long-term recipients are continuing in school, this is a measure for titulares themselves and not their children. Given this consideration it is hard to assess the impact of the Program in this critical area.

Table 14: Beneficiary Education Level, 2011-2017

\begin{tabular}{|c|c|c|c|c|c|c|c|}
\hline & 2011 & 2012 & 2013 & 2014 & 2015 & 2016 & 2017 \\
\hline Preschool or kindergarten & $5 \%$ & $5 \%$ & $5 \%$ & $4 \%$ & $4 \%$ & $4 \%$ & $8 \%$ \\
\hline Elementary school & $48 \%$ & $49 \%$ & $49 \%$ & $43 \%$ & $43 \%$ & $41 \%$ & $43 \%$ \\
\hline High school & $23 \%$ & $21 \%$ & $25 \%$ & $27 \%$ & $23 \%$ & $29 \%$ & $22 \%$ \\
\hline Post-secondary (normal basic school, college or bachelor's) & $11 \%$ & $8 \%$ & $11 \%$ & $19 \%$ & $16 \%$ & $14 \%$ & $10 \%$ \\
\hline Apprenticeship (with elementary, high school, or college) & $1 \%$ & $0.2 \%$ & $0.3 \%$ & $0.3 \%$ & $0.2 \%$ & $1 \%$ & $0.1 \%$ \\
\hline Professional & $2 \%$ & $1 \%$ & $3 \%$ & $3 \%$ & $4 \%$ & $3 \%$ & $1 \%$ \\
\hline None & $11 \%$ & $15 \%$ & $8 \%$ & $4 \%$ & $10 \%$ & $7 \%$ & $16 \%$ \\
\hline
\end{tabular}

\subsubsection{Labour Market}

The Program has not had a significant impact on the employment status of long-term beneficiaries. As discussed in the previous chapter, the Program is designed to invest in human 
capital to increase successful integration of recipient households to the formal labour force. While this investment is mostly targeted at children the workshops with required attendance by recipients do cover labour market topics. However, it appears that this investment in long-term recipients has not resulted in improved employment levels for them. This lends support to my argument that the Program fails to address the underlying structures causing poverty in Oaxaca which manifest as barriers for recipients to entering the formal labour force.

Table 15: Beneficiary Employment Status, 2011-2017

\begin{tabular}{|l|r|r|r|r|r|r|r|}
\hline & 2011 & 2012 & 2013 & 2014 & 2015 & 2016 & 2017 \\
\hline Working & $35 \%$ & $33 \%$ & $38 \%$ & $39 \%$ & $40 \%$ & $38 \%$ & $36 \%$ \\
\hline Working and studying & $1 \%$ & $1 \%$ & $1 \%$ & $2 \%$ & $2 \%$ & $1 \%$ & $0.3 \%$ \\
\hline $\begin{array}{l}\text { Not working and not looking } \\
\text { for work or employed and not } \\
\text { working }\end{array}$ & $9 \%$ & $13 \%$ & $7 \%$ & $5 \%$ & $5 \%$ & $6 \%$ & $12 \%$ \\
\hline Looking for work & $2 \%$ & $1 \%$ & $2 \%$ & $1 \%$ & $1 \%$ & $1 \%$ & $1 \%$ \\
\hline Studying & $26 \%$ & $21 \%$ & $30 \%$ & $32 \%$ & $26 \%$ & $32 \%$ & $23 \%$ \\
\hline Domestic responsibilities & $28 \%$ & $32 \%$ & $22 \%$ & $21 \%$ & $27 \%$ & $21 \%$ & $29 \%$ \\
\hline
\end{tabular}

While there has been little improvement in formal employment for long-term recipients, the proportion of recipients reporting being entrepreneurs, contractors or self-employed has increased substantially from $21 \%$ in 2011 to $37 \%$ in 2017 . This aligns with my previous discussion related to employment status in that it indicates more recipients are taking on some work, although it is likely informal.

Table 16: Beneficiary Occupation, 2011-2017

\begin{tabular}{|l|r|r|r|r|r|r|r|}
\hline & 2011 & 2012 & 2013 & 2014 & 2015 & 2016 & 2017 \\
\hline Agriculture & $19 \%$ & $31 \%$ & $16 \%$ & $23 \%$ & $33 \%$ & $16 \%$ & $22 \%$ \\
\hline Construction, low-skilled and manual labour & $12 \%$ & $11 \%$ & $16 \%$ & $14 \%$ & $8 \%$ & $12 \%$ & $9 \%$ \\
\hline Professional or skilled labour & $23 \%$ & $19 \%$ & $19 \%$ & $19 \%$ & $17 \%$ & $18 \%$ & $12 \%$ \\
\hline Entrepreneur, contractor or self-employed & $21 \%$ & $22 \%$ & $27 \%$ & $28 \%$ & $22 \%$ & $27 \%$ & $37 \%$ \\
\hline Domestic & $12 \%$ & $9 \%$ & $13 \%$ & $13 \%$ & $11 \%$ & $24 \%$ & $16 \%$ \\
\hline Cooperative or producer group & $0.3 \%$ & $0.0 \%$ & $0.0 \%$ & $0.0 \%$ & $0.0 \%$ & $0.0 \%$ & $0.0 \%$ \\
\hline Ranch hand or family business (with or without compensation) & $1 \%$ & $1 \%$ & $1 \%$ & $1 \%$ & $3 \%$ & $2 \%$ & $1 \%$ \\
\hline Other & $13 \%$ & $7 \%$ & $8 \%$ & $4 \%$ & $5 \%$ & $2 \%$ & $2 \%$ \\
\hline
\end{tabular}


Figure 11: Beneficiary Monthly Income, 2011-2017

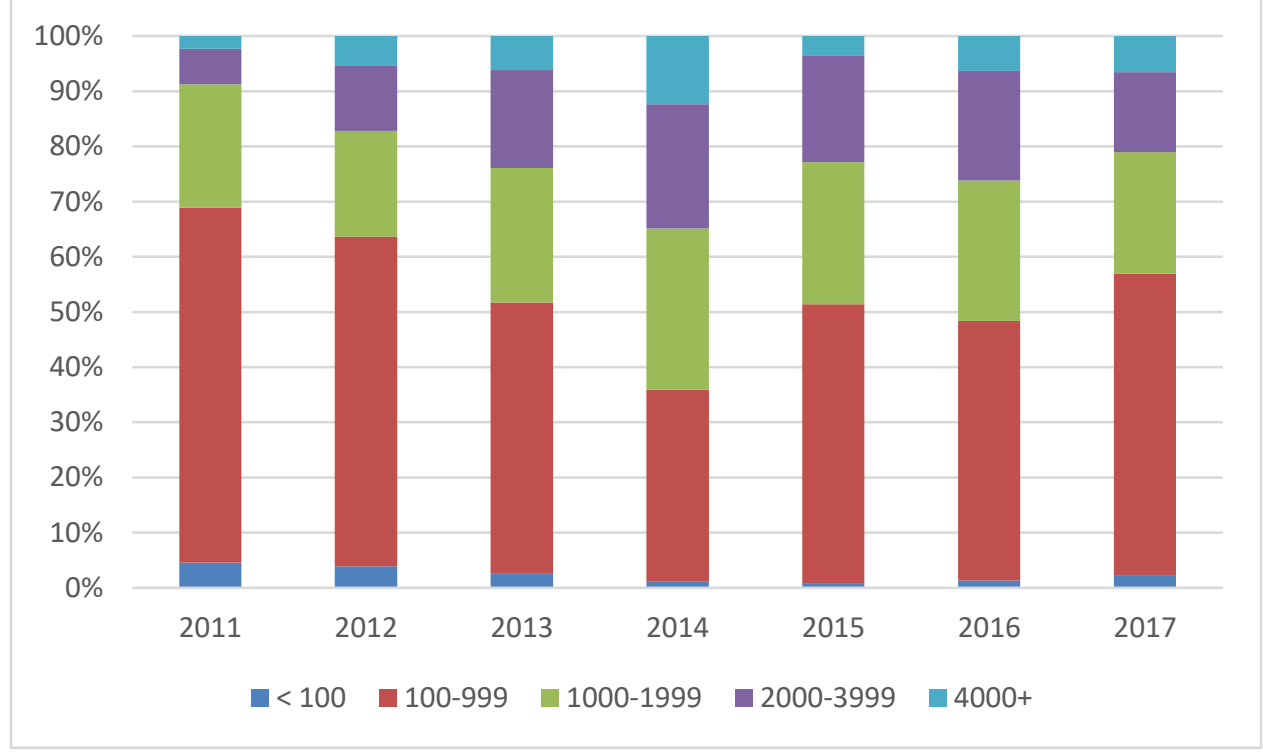

Much like nutritional expenditure and food security, monthly income fluctuates with recession indicators for Mexico. In fact, it is likely the case that the fluctuation in nutritional expenditure and food security are cause by the fluctuation in household income presented in Figure 11. I have proposed this earlier, in terms of limited resources available to beneficiary households in times of recession. As such, I can say with confidence that the Program has failed to eliminate poverty for recipients through the provision of a safety net and human capital investment.

\subsection{Conclusion}

This chapter has argued that the Program has not been effective in eliminating poverty, especially for Indigenous populations. In support of this argument, my approach has been twofold. First, I contextualized poverty in Mexico and Oaxaca using data from the OECD and CONEVAL. The purpose of this was first to establish that there had been no significant improvement in poverty in Oaxaca. Indeed, as shown in my case study of Oaxaca, poverty deepened. While there were some improvements to extreme poverty in Oaxaca, they were quite modest in comparison with 
improvements to extreme poverty in Mexico as a whole. Moreover, this improvement does not mean a reduction in poverty. Quite the contrary, the modest improvement to rates of extreme poverty means that there is an increase of the numbers living in poverty rather than a significant shift out of poverty.

I then went on to characterize Program recipients in the state of Oaxaca. This analysis provided an in-depth look at who poverty affects and how it materializes for recipients. During the period from 2011-2012 beneficiaries generally saw a decline in the living situations, providing support to my argument that the program has failed to eliminate poverty. Moreover, the high representation of Indigenous populations provides support to my argument that the Program has failed, especially for Indigenous populations.

In the economic and social outcomes section of this chapter I examine data related to the three areas which the Program targets (nutrition, health, and education) as well as labour market outcomes. Across all of these there has been little to no improvement for beneficiaries. However, across all of these categories an important pattern has emerged. Nutritional and labour market outcomes fluctuate in tandem with economic recession indicators for Mexico. ${ }^{198}$ This is further supported by the fluctuation in household income following the same pattern. This evidence supports my argument that the program leaves recipients vulnerable to economic shocks as it does not address the root causes of poverty.

198 There is not enough data collected by ENCASEH to make the same case for health outcomes. 


\section{Chapter 5: Conclusion}

The purpose of this paper has been to review and critique the family of CCT programs in Mexico, which I have referred to throughout as the Program. To guide my research, I began with the central question of whether the Program contributed to poverty reduction and the empowerment of recipients. To support this question, I examined two sub-questions: 1) how has the Program changed over time and why; and 2) does the Program have uniform outcomes across all recipients. I have argued that the Program has failed to empower recipients thereby perpetuating intergenerational poverty in Oaxaca as the program has functioned to reproduce structural inequalities caused by neoliberal restructuring in Mexico.

With these questions in mind, I reviewed the literature related to the Program and CCT programs more broadly. Through this review, five major theoretical traditions in CCT analysis emerged in the literature: neoliberal, social norms, feminist, marxist, and post-colonial. The neoliberal tradition focused on positivist analysis of the program, supporting arguments with quantitative evidence-based results. Authors within this tradition varied in their backgrounds from academic writers to policy makers involved in the crafting of the first generation of the Program, Progresa. While CCT programs are billed as tools to combat the intergenerational transmission of poverty, little research in this field has focused on the failing of the Program to enact meaningful long-term improvements to poverty in Mexico.

The second tradition in analysis of CCT programs, social norms, examined how the underlying structures of society influence these programs and how these programs can be used to further reinforce these structures. This tradition was the most varied in its analysis, ranging from the popularity of CCT programs in Latin American, to their psychological tenets. However, the 
literature in this tradition was lacking regarding how these structures affected the outcomes of the Program.

Public policy analysis of CCTs focuses the popularity and diffusion of these anti-poverty policies across the Latin America and much of the developing world. My consideration of the political and economic landscape in Mexico leading up to the development of the Program and how this impacted its introduction and subsequent expansion is unique within this tradition.

The Feminist tradition examined the gendered construction of the Program and its inability to empower titulares. While robust, this literature did not have a strong focus on quantitative evidence, rather tending towards the lived experiences of Program recipients. Moreover, this literature failed to review and critique the evolution of the Program and how this did or did not affect its gendered outcomes.

Marxist literature related to CCTs was similarly qualitative in its analysis. Critiquing these programs as appeasement strategies for those most vulnerable to the onslaught of neoliberal reform occurring in the Global South - and Latin American specifically - authors in this tradition argue that CCT programs function as a means through which the wealthy classes have historically and presently maintained their control over the poor. Much like the feminist tradition, marxist heavily relies on qualitative evidence in support of its arguments and does not undertake an evaluation of the evolution of the Program and how this affects its outcomes.

Finally, the post-colonial tradition in analysis of CCTs and the Program critique the prejudice towards Indigenous Peoples in the administration of these programs and its effects on outcomes. This analysis considers how indigeneity is constructed in an historically colonial society and its results on the construction and outcomes of the Program. Authors in this tradition examine 
the historical inequality and continued oppression faced by Indigenous peoples under these policy regimes.

My review of the literature related to CCT programs and, more specifically the Program, revealed major gaps in the literature. The first unique contribution my research has made in relation to the Program in Mexico has been to examine its policy lifespan. While there have been many reviews of the Programs at particular points in time, my thesis examined the Program from its introduction under the name Progresa, to its eventual end as Prospera. I further use a mixed analytical approach engaging both with primary qualitative and quantitative sources in support of my central premise that the Program has failed to eliminate poverty in Oaxaca and empower titulares.

To guide my analysis, I have used a composite marxist-feminist framework which examined the way in which the Program failed to address structural inequalities related to class and gender which are it root causes. To this end, I have examined and defined empowerment as they key indicator for the failure of the Program in its purpose. Operationalizing empowerment as an indicator in the results of the Program required reviewing the context in which the poor in Mexico have been oppressed and exploited and the manner in which the Program has contributed to this.

Throughout the course of its life, the Program has been a reactionary means through which the Mexican state has controlled poor populations and perpetuated gendered norms in relation to caregiving and motherhood. Expansions of CCT programs have been primarily based on their perceived popularity within development policy circles as means through which those most vulnerable to neoliberal reforms may be appeased rather than their effectiveness at eliminating poverty. Even within Mexico, the Program failed to yield significant results towards eliminating 
poverty, however the grants have had impacts on mitigating the immediate needs of recipients. Expansion of the Program within Mexico have been overwhelmingly for political gain to their popularity amongst the working classes. Reforms of the Program have remained within the neoliberal tradition of conditioning benefits to achieve behavioral reform in recipients to encourage human capital investment by recipients for their children.

Following the tracking of the evolution of the Program, I examined historical poverty trends in Mexico and Oaxaca utilizing various primary international and national data sources. This analysis was essential in choosing Oaxaca as my case study. Oaxaca breaks from national trends in poverty growth. Furthermore, Mexico's Indigenous population is heavily concentrated in Oaxaca. For these reasons, Oaxaca constituted a unique case study in the failure of the Program at eliminating intergenerational poverty and empowering its recipients.

I utilized ENCASEH survey data of long-term recipients of the Program to examine its outcomes. While the evaluation of the Program by the Mexican state has been extensive, little attention has been paid to the intergenerational component of poverty. For this reason, I selected recipient and household datasets which had previously answered four or more evaluation surveys.

While surveys of recipients have been administered as part of the evaluation of the Program since 2004, much of the data is only reliably available from 2011 onwards. For this reason, as well as when the data was accessed for this thesis, my period of analysis consisted of the period from 2011 to 2017. While there are limitations to the data available, several significant trends emerged from this analysis. First, there has been little to no improvement in the areas targeted by the program: health, education, and nutrition. Moreover, the labour market outcomes of recipients often worsened and were vulnerable to economic shocks coinciding with positive recession indicators in Mexico. 
When reviewed in tandem, my theoretical qualitative analysis of the Program and quantitative analysis of the its outcomes reveal a disconnect between the Programs purported goals and its achievements. There are many possible reasons that this is the case, but I believe that this is due to the Program's focus on administrative efficiencies and economic outcomes rather than targeting the underlying systemic causes of intergenerational poverty. This is supported when applying the indigeneity lens to the analysis which highlights the structural inequality and historical oppression of Indigenous peoples in Mexico, and Oaxaca more specifically.

I have approached this research from many perspectives, however, further areas for investigation remain. While I did undertake quantitative analysis of the Program, I did not use statistical techniques to measure the effects of the Program. Understanding what the effects are, while important, is only one part of a larger puzzle. To fully understand how the Program affects recipients would require examining the depth of these effects and whether they are statistically significant. Another important piece missing from this thesis is undertaking this analysis for the full lifespan of the Program. Unfortunately, due to time constraints I was not able to use datasets including the final year of the Program, 2018 following its replacement with education bursaries under the López-Obrador administration beginning in 2019. While there were not major reforms to the structure of the Program during this time, it is impossible to get the whole picture without having all the information. Moreover, examining how poverty changes or fails to change following the elimination of the Program would help to fill in these missing pieces as well.

Another limitation of this research has been the lack of primary qualitative evidence. While data provides the possibility of studying the magnitudes of effects and other quantifiable results, it is only part of the story. Understanding peoples' lived experiences with the Program and how it has affected their daily lives and choices would be of real value in supporting the arguments set 
forth in this thesis. The richness of understanding enabled by this type of research could only add value and context to my analysis of the Program. 


\section{Bibliography}

Ávila Jaquez, Carmen and Mariana Gabarrot Arenas. "Retos locales de la política social en México: el funcionamiento del Programa de Desarollo Humano "Oportunidades" en una comunidad indígina bajo el sistema de gobierno de usos y costumbres." Revista Confines, 5 no. 10 (2009): 67-82.

Ayala Galí, Elena. "El Programa Oportunidades en Garcías y las Relaciones de Género." In Los Retos de la Política Social en México: Combate a la Pobreza y Equidad de Género. Dissertation, Benemérita Universidad Autónoma de Puebla, 2016.

Bartra, Roger. The Mexican Transition: Politics, Culture, and Democracy in the TwentyFirst Century. Cardiff: University of Wales Press, 2013.

Borges Sugiyama, Natasha. "Bottom-Up Policy Diffusion: National Emulation of a Conditional Cash Transfer Program in Brazil.” Publius 42, no.1 (2012): 25-51.

Borges Sugiyama, Natasha. "The Diffusion of Conditional Cash Transfer Programs in the Americas." Global Social Policy 11 no (2-3): 250-278.

Borzutzky, Silvia. "Conditional Cash Transfers in Latin America and Anti-Poverty Policies in Chile: Why is Chile's Market Economy Unable to Reduce Poverty and Inequality?" Poverty \& Public Policy 4, no. 1 (2012): 1-23.

Bradshaw, Sarah. "From Structural Adjustment to Social Adjustment: A Gendered Analysis of Conditional Cash Transfer Programmes in Mexico and Nicaragua." Global Social Policy 8, no. 2 (2008): 188-207.

Cena, Rebeca and Florencia Chahbenderian. "El abordaje estatal de la pobreza en Programas de Transferencias Monetarias Condicionades." Revista Latinoamericana de Ciencias Sociales 13, no. 1 (2015): 123-136.

Centeno, Miguel. Democracy Within Reason: Technocratic Revolution in Mexico. Pennsylvania: The Pennsylvania State University Press, 1994.

Charnock, Greig. "Improving the Mechanisms of Global Governance? The Ideational Impact of the World Bank on the National Reform Agenda in Mexico." New Political Economy 11, no. 1 (2006): 73-98.

Cookson, Tara Patricia. Unjust Conditions: Women's Work and the Hidden Cost of Cash Transfer Programs. Oakland: University of California Press, 2018.

Cookson, Tara Patricia. "Working for Inclusion? Conditional Cash Transfers, Rural Women, and the Reproduction of Inequality." Antipode 48, no. 5 (2016): 11871205 . 
Cooney, Paul. "The Mexican Crisis and the Maquiladora Boom: A Paradox of Development or the Logic of Neoliberalism?" Latin American Perspectives 118, no. 28 (2001): 55-83.

Cunha, Jesse. "Testing Paternalism: Cash Versus In-Kind Transfers." American Economic Journal: Applied Economics 6, no. 2 (2014): 195-230.

Cypher, James. "Developing Disarticulation Within the Mexican Economy." Latin American Perspectives 118, no. 3 (2001): 11-37.

Dapuez, Andrès. "Supporting a Counterfactual Futurity: Cash Transfers and the Interface between Multilateral Banks, the Mexican State, and its People." The Journal of Latin American and Caribbean Anthropology 21 no. 3 (2016): 560-583.

Dávila Lárraga. How does Prospera Work? Best Practices in the Implementation of Conditional Cash Transfer Programs in Latin America and the Caribbean. Washington, D.C.: Inter-American Development Bank - Social Protection and Health Division, 2016.

De Brauw, Alan and John Hoddinott. "Must Conditional Cash Transfer Programs be conditioned to be Effective? The Impact of Conditioning on School Enrollment in Mexico." Journal of Development Economics 96, no. 2 (2011): 359-370.

Dygert, Holly. "The Fight Against Poverty and the Gendered Remaking of Community in Mexico: New Patriarchal Collusions and Gender Solidarities.” Political and Legal Anthropology Review 40, no. 1 (2017): 171-187.

"Ejercicio de adecuación histórica de la carencia por acceso a la seguridad social 2016 a la serie 2010-2014." CONEVAL. Accessed August 17, 2019. https://www.coneval.org.mx/Medicion/MP/Documents/Pobreza 16/Notas_Pobrez a 2016/Nota tecnica 2 ajuste seguridad social.pdf.

Escobar, Arturo. "Introduction: Development and the Anthropology of Modernity." In Encountering Development: The Making and Unmaking of the Third World. Princeton: Princeton University Press, 1995.

Falconer, Chantelle Alena. "(En)Gendering Equality? Conditional Cash Transfers as National Development in Post-Neoliberal Ecuador." The Journal of Latin American and Caribbean Anthology 23, no. 2 (2018): 320-337.

Federici, Silvia. "The Accumulation of Labor and the Degradation of Women: Constructing 'Difference' in the 'Transition to Capitalism'." In Caliban and the Witch. Brooklyn: Autonomedia, 1998. 
Federici, Silvia. "The Reproduction of Labour Power in the Global Economy and the Unfinished Feminist Revolution.” In Revolution at Point Zero: Housework, Reproduction, and Feminist Struggle. Brooklyn: PM Press, 2012.

Fenwick, Tracy. "From CCTs to a Social Investment Welfare State? Brazil's 'New' ProPoor Strategy." Development Policy Review 35, no. 5 (2017): 659-674.

Flores-Macías, Gustavo. "Mexico's Stalled Reforms." Journal of Democracy 27, no. 2 (2016): 66-78.

Ferguson, James. "The Uses of Neoliberalism." Antipode 41, no. 1 (2009): 166-184.

Franko, Patrice. The Puzzle of Latin American Economic Development. Lanham: Rowman \& Littlefield Publishing Group, 2007.

Freeland, Valerie. "Beyond Robert Jackson: Post-Colonial Realities and the Patronage State." International Politics 54, no. 2 (2017): 125-143.

Garmany, Jeff. "Strategies of Conditional Cash Transfers and the Tactics of Resistance." An Environment and Planning 49, no. 2 (2017): 372-388.

Gates, Marilyn. "The Debt Crisis and Economic Restructuring: Prospects for Mexican Agriculture." In Neoliberalism Revisited: Economic Restructuring and Mexico's Political Future, edited by Gerardo Otero, 43-62. Boulder: Westview Press, 1996.

Gil-García, Óscar. "Gender Equality, community divisions, and autonomy: The Prospera Conditional CashTransfer Program in Chiapas, Mexico." Current Sociology, 64 no. 3 (2016): 447-469.

González de la Rocha, Mercedes and Agustín Escobar Latapí. "Indigenous Girls in Rural Mexico: A Success Story?" Girlhood Studies, 9 no. 2 (2016): 65-81.

Greene, Kenneth. Why Dominant Parties Lose: Mexixo's Democratization in Comparaticve Perspective. Cambridge: Cambridge University Press, 2007.

Hamilton, Nora. Mexico: Political, Social and Economic Revolution. New York: Oxford University Press, 2011.

Hanlon, Josheph et al. Just Give Money to the Poor: The Development Revolution from the Global South. Boulder: Kumarian Press, 2013.

Hryciuk, Renata. "Mothering for Neoliberal Times. Mazahua Women, Poverty and the Cultural Politics of Development in Central Mexico." Polish Sociological Review, no. 200 (2017): 523-543. 
Indicadores socioeconómicos de los pueblos indígena de México, 2015. Mexico City: Gobierno de México - Comisión nacional para el desarrollo de los pueblos indígenas, 2016.

"Información Socioeconómica y Demográfica de PROSPERA (Base de Datos)." Accessed November, 2018. https://evaluacion.prospera.gob.mx/es/dae/encaseh.php.

Jenson, Jane. "Broadening the Frame: Inclusive Growth and the Social Investment Perspective." In After '08: Social Policy and the Global Financial Crisis, edited by Stephen McBride, Rianne Mahon, and Gerard Boychuk, 40-58. Vancouver: UBC Press, 2015.

Jenson, Jane and Nora Nagels. "Social Policy Instruments in Motion. Conditional Cash Transfers from Mexico to Peru." Social Policy and Administration 52, no. 1 (2016): 323-342.

Kapur, Davesh. “The IMF A Cure or a Curse?” Foreign Policy no. 111 (1998): 114-129.

Kershaw, Paul. "Averting a Global Financial Crisis: the US, the IMF, and the Mexican Debt Crisis of 1976." The International History Review 40, no. 2 (2018): 292-314.

Kunz, Rahel. "The crisis of social reproduction in rural Mexico: Challenging the 'reprivatization of social reproduction' thesis." Review of International Political Economy 17, no. 5 (2010): 913-945.

La población indígena en al México rural: situación actual y perspectivas. Mexico City: Gobierno de México - Centro de Estudios para el Desarrollo Rural Sustentable y la Soberanía Alimentaria, 2015.

Lavinas, Lena. “21 ${ }^{\text {st }}$ Century Welfare.” New Left Review 84 (2013): 5-40.

Levy, Santiago. Progress Against Poverty: Sustaining Mexico's Progresa-Oportunidades Program. Washington: The Brookings Institution, 2006.

Lopez-Calva, Luis and Harry Patrinos. "Exploring the Differential Impact of Public Interventions on Indigenous People: Lessons from Mexico's Conditional Cash Transfer Program." Journal of Human Development and Capabilities 16, no. 3 (2015): 452-467.

Luccisano, Lucy. "Mexican Anti-Poverty Programs and the Making of "Responsible" Poor Citizens (1995-2000).” PhD dissertation, York University, 2002. 
Luccisano, Lucy. "The Mexican Oportunidades Program: Questioning the Linking of Security to Conditional Social Investments for Mothers and Children." Canadian Journal of Latin American \& Caribbean Studies 31, no. 62 (2006): 53-85.

Luccisano, Lucy and Laura Macdonald. "The Impact of the Global Financial Crisis on Mexican Social Policy." In After '08: Social Policy and the Global Financial Crisis edited by Stephen McBride, Rianne Mahon and Gerard Boychuk, 181196.Vancouver: UBC Press, 2015.

Maxfield, Sylvia. Governing Capital: International Finance and Mexican Politics. Ithaca: Cornell University Press, 1990.

"Medición de la pobreza." CONEVAL. Last modified 2018. https://www.coneval.org.mx/Medicion/MP/Paginas/Lineamientos DOF.aspx.

"Medición de la pobreza, Estados Unidos Mexicanos, 2016." Estimations by Consejo Nacional de Evaluación de la Política de Desarrollo Social (CONEVAL). Accessed March 8, 2019. https://coneval.org.mx/Medicion/MP/Paginas/Pobreza_2016.aspx.

"Medición de la pobreza, Estados Unidos Mexicanos, 2016: Porcentaje, número de personas y carencias promedia por indicador de pobreza, según entidad federativa, 2010-2016." Estimations by Consejo Nacional de Evaluación de la Política de Desarrollo Social (CONEVAL). Accessed March 8, 2019, https://coneval.org.mx/Medicion/PublishingImages/Pobreza 20082016/medicion-pobreza-entidades-federativas-2016.JPG.

Mills, Lisa. The Limits of Trust: The Millennium Development Goals, Maternal Health, and Health Policy in Mexico. Montreal: McGill University Press, 2017.

Molyneux, Maxine. "Mothers at the Service of the New Poverty Agenda: The PROGRESA/Oportunidades Programme in Mexico." In Gender and Social Policy in a Global Context, edited by Shireen Hassin and Shahra Razavi. New York: Palgrave Macmillan, 2006.

"Non-contributory Social Protection Programmes Database - Oportunidades (Human Development Programme, formerly "Progresa") (1997-2014)." United Nations Economic Commission for Latin America and the Caribbean (UNECLAC). Last modified November 16, 2017. https://dds.cepal.org/bpsnc/programme?id=22.

"Non-contributory Social Protection Programmes Database - Prospera: Social Inclusion Programme (2014-2019)." UNECLAC. Last modified May 29, 2019. https://dds.cepal.org/bpsnc/programa?id=92. 
Nota Técnica de Bases Panel de Encuestas de Características Socioeconómicas de Hogares (ENCASEH) 2004-2018. Mexico City: SEDESOL - Prospera, 2019.

"OECD based Recession Indicators for Mexico from the Period following the Peak through the Trough." Federal Reserve Bank of St. Louis (FRED). Last modified Dec. 9, 2019. https://fred.stlouisfed.org/series/MEXRECD.

Ochman, Marta. "Políticas sociales y empoderamiento de las mujeres. Una promesa incumplida." Estudios Políticos, no. 48 (2016): 32-51.

Otero, Gerado. "Neoliberal Reform and Politics in Mexico: An Overview." In Neoliberalism Revisited: Economic Restructuring and Mexico's Political Future, edited by Gerardo Otero, 1-26. Boulder: Westview Press, 1996.

Ozanira da Silva e Silva, Maria. "Income Transfer Programs as a Strategy against Poverty in Latin America: Reality and Limits." Social Development Issues 40., no. 2 (2018):1-9.

Parker, Susan and Petra Todd. "Conditional Cash Transfers: The Case of Progresa/Oportunidades." Journal of Economic Literature 55, no. 3 (2017): 866915.

Peck, Jamie. "Geographies of Policy: From Transfer-diffusion to Mobility-mutation." Progress in Human Geography 35, no. 6 (2011): 773-797.

Pérez-Muñoz, Cristian. "What is Wrong with Conditional Cash Transfer Programs?" Journal of Social Philosophy 48, no. 4 (2017): 440-460.

"Población total por Entidad federativa, Grupo quinquenal de edad, Periodo y Sexo." Instituto Nacional de Estadísticas y Geografia (INEGI). Accessed August 17, 2018.

https://en.www.inegi.org.mx/app/tabulados/pxweb/inicio.html?rxid=d518b312a32e-4d23-a8dd-08a64c187a6c\&db=Poblacion\&px=poblacion 01 .

"Poverty Rate." OECD. Accessed August 17, 2019. https://data.oecd.org/inequality/poverty-rate.htm\#indicator-chart.

"Progresa: Programa de Educación, Salud y Alimentación.” Progresa. Mexico City, 1998.

Radcliffe, Sarah. "The Shrinking Commons and Uneven Geographies of Development." In Releasing the Commons: Rethinking the Futures of the Commons edited by Amin Ash and Howell Philip, 126-144. New York: Routledge, 2016. 
Radel, Claudia et al. "The Gender Dynamics of Conditional Cash Transfers and Smallholder Farming in Calakmul, Mexico." Women's Studies International Forum, 65 (2017): 17-27.

Rawlings, Laura and Gloria Rubio. "Evaluating the Impact of Conditional Cash Transfer Programs.” The World Bank Research Observer 20, no. 1 (2005): 29-55.

Ramírez, Vivana. "CCTs Through a Wellbeing Lens: The Importance of the Relationship Between Front-Line Officers and Participants in the Oportunidades/Prospera Programme in Mexico.” Social Policy and Society, 15 no. 3 (2016): 451-464.

Teichman, Judith. "Multilateral Lending Institutions and Transnational Policy Networks in Mexico and Chile." Global Governance 13, no. 4 (2007): 557-573.

Teichman, Judith. "The World Bank and Policy Reform in Mexico and Argentina." Latin American Politics and Society 46 no. 1 (2004): 39-74.

Tickell, Adam and Jamie Peck. "Making Global Rules: Globalization or Neoliberalization?” In Remaking the Global Economy: Economic Geographical Perspectives, edited by Jamie Peck and Henry Wai-Chung Yeung, 163-181. Thousand Oaks: Sage Publications, 2003.

Wilson, Tamar Diana. "The Informal Economy and Social Programs in Mexico: A Critique." Latin American Perspectives, 45 no. 1 (2018): 130-145.

Wilson, Tamar Diana. "Mexico's Rural Poor and Targeted Educational and Health Programs." Human Organization 74, no. 3 (2015): 207-21.

Woods, Ngaire. The Globalizers: The IMF, the World Bank, and Their Borrowers. Ithaca: Cornell University Press, 2007.

Wolf, Sharon et al. "Drawing on Psychological Theory to Understand and Improve AntiPoverty Policies: The Case of Conditional Cash Transfers." Psychology, Public Policy, and Law 19 no. 1 (2013): 3-14.

Yanes, Pablo. “¿De las transferencias monetarias condicionadas al ingreso ciudadano universal?”'Acta Sociológica, no. 70 (2016): 129-149.

Yaschine, Iliana. "Is Education Enough to Overcome Poverty? Analysis of the Occupational Stratification of Rural Youths in Mexico." In Revista Mexicana de Ciencias Políticas y Sociales, 60 no. 223 (2015): 377-405.

Yaschine, Iliana. "Progresa-Oportunidades-Prospera, veinte años de historia." In $E l$ Progresa-Oportunidades-Prospera, a 20 años de su creación. Coordinated by 
Hernández Licona, Gonzalo, Thania De la Garza, Janet Zamudio and Iliana Yaschine, 31-65. Mexico City: CONEVAL, 2019. 